\title{
Geochronology of Mexican mineral deposits. VII: the Peña Colorada magmatic-hydrothermal iron oxide deposits (IOCG “clan"), Colima
}

\author{
Antoni Camprubí, Elena Centeno-García, Gustavo Tolson, Alexander Iriondo, Berlaine Ortega, \\ Daniel Bolaños, Fanis Abdullin, José L. Portugal-Reyna, Mario A. Ramos-Arias
}

\author{
Antoni Camprubí \\ camprubitaga@gmail.com \\ Elena Centeno-García \\ Gustavo Tolson \\ Berlaine Ortega \\ Instituto de Geología, Universidad Nacional \\ Autónoma de México. Ciudad Universitaria, \\ 04510 Coyoacán, CDMX, Mexico.
}

\section{Alexander Iriondo \\ Fanis Abdullin \\ Centro de Geociencias, Universidad Nacional Autónoma de México. Boulevard Juriquilla 3001, 76230 Querétaro, Qro., Mexico.}

\section{Daniel Bolaños}

Instituto Mexicano del Petróleo. Eje Central Lázaro Cárdenas 152, San Bartolo Atepehuacan, 07730 Gustavo A. Madero, CDMX, Mexico.

\section{José L. Portugal-Reyna}

Consorcio Minero Benito Juárez-Peña Colorada S.A. de C.V., Av. del Trabajo 1000, 28876 Manzanillo, Col., Mexico.

\section{Mario A. Ramos-Arias}

Earth and Environmental Sciences, University of Michigan. 2534 C. C. Little Building, 1100 North University Avenue, Ann Arbor, MI 48109-1005, United States of America.

BOL. SOC. GEOL. MEX. 2018

VOL. 70 NO. 3

P. $633-674$

http://dx.doi.org/10.18268/BSGM2018v70n3a4

Manuscript received: January 8, 2018. Corrected manuscript received: May 12, 2018 Manuscript accepted: May 25, 2018.
ABSTRACT

The Peña Colorada mineralized area contains several iron oxide-apatite (IOA) deposits around the arguably richest known iron resource in Mexico. The Lower Cretaceous volcano-sedimentary host rock sequence has been subjected to several episodes of hydrothermal alteration, each accompanied by a distinct episode of faulting and intrusion (calc-alkaline to tholeiitic). Faulting is partly associated with the reactivation of cryptic structural corridors in basement rocks. High-resolution ${ }^{40} \mathrm{Ar} /{ }^{39} \mathrm{Ar}$ and apatite fission track (AFT) dating of this deposit and the adjacent Arrayanes prospect reveal the following sequence of events that range from the latest Cretaceous to the earliest Eocene: (1) intrusion of a $67.6 \pm 3.5 \mathrm{Ma}$ magnetite-bearing diorite with associated skarn/skarnoid metamorphism that was coeval or predated $\mathrm{N}-\mathrm{S}$ to NNW-SSE faulting; (2) approximately 63.26 Ma syenite-like potassic alteration with disseminated magnetite, predated by $\mathrm{N}-\mathrm{S}$ to NNW-SSE faulting and postdated by WNW-ESE faulting; (3) intrusion of $62.0 \pm 2.5 \mathrm{Ma}$ diorite and $59.39 \pm 0.21$ $\mathrm{Ma}$ andesite dikes that predate the main mineralization event at 55.72 to $54.84 \mathrm{Ma}$ of large semi-stratabound massive and disseminated bodies; (4) intrusion of a $53.3 \pm$ 3.0 Ma magnetite-bearing gabbro and $53 \pm$ 2 Ma pegmatoid magnetite + fluorapatite veins at the Arrayanes prospect, which overlap the WNW-ESE faulting; (5) 50.70 to $48.18 \mathrm{Ma}$ polymictic magnetite breccia as the last stage of mineralization in the area, predated by $\mathrm{E}-\mathrm{W}$ faulting; and (6) reactivation of WNW-ESE faults and later NE-SW faults. Therefore, the total age span of the Peña Colorada deposit ranges between approximately 19 and 23 million years. The closeness in age between intrusions and mineralization in the Arrayanes prospect, their confinement between the WNW-ESE and E-W structural domains, and mingling or mixing structures between

\section{RESUMEN}

El área mineralizada de Peña Colorada contiene numerosos depósitos de óxidos de hierro-apatita (IOA) alrededor de lo que cabalmente es el mayor recurso en hierro conocido de México. El depósito de Peña Colorada está emplazado en una secuencia volcanosedimentaria del Cretácico Inferior y está constituido por diversas etapas de mineralización precedidas por cambios en orientación del fallamiento (asociado en parte a la reactivación de corredores estructurales cripticos en el basamento) $y$ detonadas por intrusiones de rocas calci-alcalinas a toleiticas. El fechamiento de alta resolución mediante ${ }^{40} \mathrm{Ar} /{ }^{39} \mathrm{Ar}$ y trazas de fisión en apatita (AFT) en este depósito y el adyacente prospecto de Arrayanes permite determinar la siguiente secuencia de eventos que abarcan desde el Cretácico terminal hasta el Eoceno más temprano: (1) intrusión de una diorita con magnetita de 67.6 \pm 3.5 Ma con metamorfismo de tipo skarn/skarnoide asociado, que fue simultánea con o antecedió al fallamiento $\mathcal{N}$-S a $\mathcal{N N W - S S E , ~ ( 2 ) ~ a l t e r a c i o ́ n ~ p o t a ́ s i c a ~ c o n ~}$ magnetita diseminada de $\sim 63.26 \mathrm{Ma}$, antecedida por fallamiento $\mathcal{N}-S$ a $\mathcal{N N W}$-SSE y seguida de fallamiento WNW-ESE, (3) intrusión de una diorita de $62.0 \pm 2.5$ Ma y de diques andesíticos de $59.39 \pm 0.21 \mathrm{Ma}$ que anteceden a la etapa de mineralización principal de 55.72 a 54.84 Ma con grandes cuerpos semi-estratoligados masivos y diseminados, (4) estos últimos se superponen temporalmente con un gabro con magnetita de 53.3 \pm 3.0 Ma y vetas pegmatoides de magnetita + flourapatita del prospecto de Arrayanes, igualmente antecedidos por fallamiento WNW-ESE, (5) brecha polimictica de magnetita de 50.70 a 48.18 Ma como última etapa de mineralización en el área, antecedida por fallamiento $E-W, y$ (6) reactivación de fallas WNW-ESE, y fallas NE-SW más tardias. Por lo tanto, la variación total en edad del depósito de Peña Colorada abarca entre $\sim 19$ y $\sim 23$ millones de años. La proximidad en edad entre las intrusiones y las mineralizaciones en el prospecto de Arrayanes, su confinamiento entre los dominios estructurales WNW-ESE y E-W, y las estructuras tipo "mingling" $y$ "mixing" entre gabros y dioritas con magnetita magmática aso- 
gabbro and diorite with an associated magmatic magnetite enrichment support the idea of a close genetic link between such intrusives and IOA hydrothermal mineralization. All mineralization events at Peña Colorada are associated with pervasive potassic to propylitic alteration, whereas at Arrayanes they are associated with dominant sodic alteration instead. Alteration features are suggestive of relatively shallow and deep formation of these deposits, respectively . Event 3 thermally reset fluorapatite in fragments of pegmatoid magnetite + fluorapatite + diopside associations (dated at $59 \pm 2 \mathrm{Ma}$, AFT) within the polymictic breccia, which were sampled from a deep orebody (still to be found) and that would be likely associated with event 1 or 2. Consequently, exploration endeavors at depth at Peña Colorada may be considered promising.

In this study, we use numerous geological and geochemical proxies to constrain the likeliest genetic model for the Peña Colorada and neighboring deposits: (a) the nearness in time and space between hydrothermal mineralization and magnetite-rich, tholeiitic, relatively oxidized intrusive rocks; (b) the occurrence of key mineral associations (i.e. magnetite + fluorapatite \pm diopside veins); (c) the exclusive occurrence of fluorapatite in lieu of other apatites; (d) the composition in key major cations ( $\mathrm{Ca}, \mathrm{Fe}, \mathrm{Na}, \mathrm{Mn}$ ) in fluorapatite; (e) the correlations between $\mathrm{Ni} / \mathrm{Cr}$ vs. $\mathrm{Ti}$ values, between $\mathrm{Ti}+\mathrm{V}$ vs. $\mathrm{Ni} /(\mathrm{Cr}+\mathrm{Mn})$ values, between $\mathrm{Ti}+\mathrm{V}$ vs. $\mathrm{Al}+\mathrm{Mn}$ values, and $\mathrm{Mg}$ contents in magnetite; (f) pyroxene thermometry; (g) $\log f\left(\mathrm{O}_{2}\right)$ values calculated from Mn contents in fluorapatite; and (h) normalized REE patterns, and इLREE and SHREE contents in fluorapatite. These proxies indicate that IOA deposits in the Peña Colorada area have a hydrothermal origin with a strong magmatic influence (magmatic-hydrothermal iron oxide, or MHIO, deposits) that formed under high oxygen fugacities and "moderate" temperatures, and with a high geochemical affinity with IOCG and Kiruna-type deposits or the general IOCG "clan" (for both hydrothermal minerals and associated hypabyssal rocks). Relatively high $\mathrm{Ti}$ contents in magnetite, and high Ce and low Eu contents in fluorapatite in these deposits (with respect to typical compositions in IOCG "clan" deposits) are geochemical features still in need of further explanation. The correlation between regional and local structural domains and the geochronologic study in this paper constrain the possible ages of such domains as follows: (1) the N-S to NNW-SSE domain can be bracketed between 67.6 and $63.26 \mathrm{Ma},(2)$ the WNW-ESE domain between 63.26 and $59.39 \mathrm{Ma},(3)$ the $\mathrm{E}-\mathrm{W}$ domain between 54.84 and $50.70 \mathrm{Ma}$, (4) the WNW-ESE to NW-SE domain is younger than $48.18 \mathrm{Ma}$, and (5) the NE-SW domain is still active. The structural analysis also shows that the massive orebody at Peña Colorada is partially stratabound but its emplacement was also controlled by low-angle Laramide faults, and that hydrothermal fluids were preferentially driven through volcanosedimentary rocks. The latter characteristic is not only a matter of the stratigraphic distribution of relatively pervasive versus impervious rocks but also of the lateral distribution of such rocks due to $\mathrm{N}-\mathrm{S}$ strikeslip faults. As additional results of this study, we determined that the conglomerates atop the host volcano-sedimentary sequence that were initially attributed to the Cerro de la Vieja Formation cannot be older than 67.6 Ma, and that the IOA deposits at Peña Colorada would be formed at depths of only a few hundred meters.

Keywords: iron oxide-apatite deposits, IOA, magmatic-hydrothermal, magnetite, fluorapatite, REE chemistry, fission track dating, ${ }^{40} \mathrm{Ar} /{ }^{39} \mathrm{Ar}$ thermochronology, structural analysis. ciada a éstas, apoyan la idea de un nexo genético cercano entre dichos intrusivos y las mineralizaciones hidrotermales de IOA. Todas las etapas de mineralización en Peña Colorada están asociadas a alteraciones potásicas a propilíticas penetrativas mientras que, por el contrario, en Arrayanes están asociadas con alteración sódica dominante. Dichos rasgos sugieren el emplazamiento somero y profundo de dichos depósitos, respectivamente. El evento 3 reseteó térmicamente la fluorapatita de los fragmentos de las asociaciones pegmatoides de magnetita + fluorapatita + diópsido (fechada en $59 \pm 2 \mathrm{Ma}$, AFT) en la brecha polimíctica, que fueron incorporados a partir de un cuerpo mineralizado (aún no hallado) y que pudiera estar asociado con los eventos 1 o 2. En consecuencia, la exploración a mayor profundidad en el depósito de Peña Colorada puede considerarse prometedora.

En el presente estudio, utilizamos numerosas aproximaciones geológicas y geoquímicas a fin de precisar el modelo geológico más probable para el depósito de Peña Colorada y sus depósitos adyacentes: (a) la proximidad en espacio y tiempo entre las mineralizaciones hidrotermales y las rocas intrusivas ricas en magnetita magmática, de carácter toleítico, oxidado y primitivo, (b) la presencia de asociaciones minerales clave (i.e. vetas de magnetita + fluorapatita \pm diópsido), (c) la presencia exclusiva de fluorapatita en lugar de otras apatitas, (d) la composición en cationes mayores clave ( $\mathrm{Ca}, \mathrm{Fe}, \mathrm{Na}, \mathrm{Mn}$ ) en fluorapatita, (e) las correlaciones entre valores de $\mathrm{Ni} / \mathrm{Cr}$ vs. $\mathrm{Ti}$, entre valores de $\mathrm{Ti}+V$ vs. $\mathrm{Ni} /(\mathrm{Cr}+\mathrm{Mn})$, entre valores de $T i+V$ vs. $A l+M n$, y los contenidos netos de $M g$ en magnetita, (f) termometría de piroxenos, $(g)$ valores de $\log \mathrm{f}\left(O_{2}\right)$ calculados a partir del contenido de Mn en fluorapatita, y (h) patrones de REE y valores netos de $\Sigma L R E E$ y ऽHREE en fluorapatita. Estas aproximaciones indican que los depósitos de IOA en el área de Peña Colorada son de origen hidrotermal con una fuerte influencia magmática (depósitos de óxidos de hierro magmático-hidrotermales, u OHMH) que se formaron bajo altas fugacidades de oxígeno y temperaturas "moderadas", y con una alta afinidad geoquímica con depósitos tipo IOCG y Kiruna o del 'clan' IOCG en general (respecto tanto a los minerales hidrotermales como a las rocas hipabisales asociadas). Rasgos geoquímicos como contenidos relativamente altos en Ti en magnetita, y contenidos altos en Ce y bajos en Eu en fluorapatita (respecto a las composiciones típicas en depósitos del 'clan' IOCG) todavía necesitan explicaciones adicionales.

La correlación entre los dominios estructurales regionales y locales y el estudio geocronológico en el presente trabajo limitan las edades posibles de dichos dominios como sigue: (1) el dominio $\mathcal{N}-S$ a $\mathcal{N N W}$-SSE puede ser limitado entre $67.6 y$ 63.26 Ma, (2) el dominio WNW-ESE entre 63.26 y $59.39 \mathrm{Ma}$, (3) el dominio E-W entre 54.84 y $50.70 \mathrm{Ma}$, (4) el dominio WNW-ESE a NW-SE es más reciente que $48.18 \mathrm{Ma}, y$ (5) el dominio $\mathrm{NE}-\mathrm{SW}$ sigue activo en la actualidad. El análisis estructural también permitió determinar que el cuerpo mineralizado masivo semi-estratoligado se encuentra parcialmente estratoligado pero su emplazamiento estuvo controlado adicionalmente por fallas de bajo ángulo de la orogenia Larámide, y que los fluidos hidrotermales fueron canalizados preferentemente a través de rocas volcanosedimentarias. Esta última característica no tiene sólo que ver con la distribución estratigráfica de rocas relativamente permeables e impermeables sino también con la distribución lateral de dichas rocas debido a fallas laterales $\mathcal{N}-S$. Como consecuencias adicionales del presente estudio, se ha determinado que los conglomerados que sobreyacen la secuencia volcanosedimentaria encajonante, que inicialmente habian sido atribuidos a la Formación Cerro de la Vieja, no pueden ser más antiguos de 67.6 Ma, y que que la formación de los depósitos IOA en Peña Colorada se formaron a sólo unos pocos centenares de metros de profundidad.

Palabras clave: depósitos de óxidos de hierro-apatita, IOA, magmatico-hidrotermal, magnetita, fluorapatita, química de REE, fechamiento por trazas de fisión, termocronología de ${ }^{40} \mathrm{Ar} /{ }^{39} \mathrm{Ar}$, análisis estructural. 


\section{Introduction}

The Peña Colorada iron oxide-apatite (IOA) deposit is located in the northern part of the state of Colima, SW Mexico. The majority of magmatic-hydrothermal iron oxide deposits (or IOCG "clan" deposits) in SW Mexico span Late Cretaceous to Eocene ages (Camprubí, 2009, 2013, 2017; Camprubí and González-Partida, 2017). These are located less than approximately $200 \mathrm{~km}$ inland from the paleo-trench in the Pacific margin (Figure 1), not unlike similar deposits in the Andean coastal ranges (Camprubí, 2017; Camprubí and González-Partida, 2017). Their distribution follows that of Late Cretaceous to Eocene magmatism, although the regional tectonomagmatic regime and its evolution are poorly known. Likewise, no clear genetic association between magmatism and such iron deposits has been established.

The Peña Colorada deposit is the largest iron deposit currently mined in Mexico, with resources over $300 \mathrm{Mt}$ and average grades between 50 and 60\% Fe (Corona-Esquivel and Henríquez, 2004).

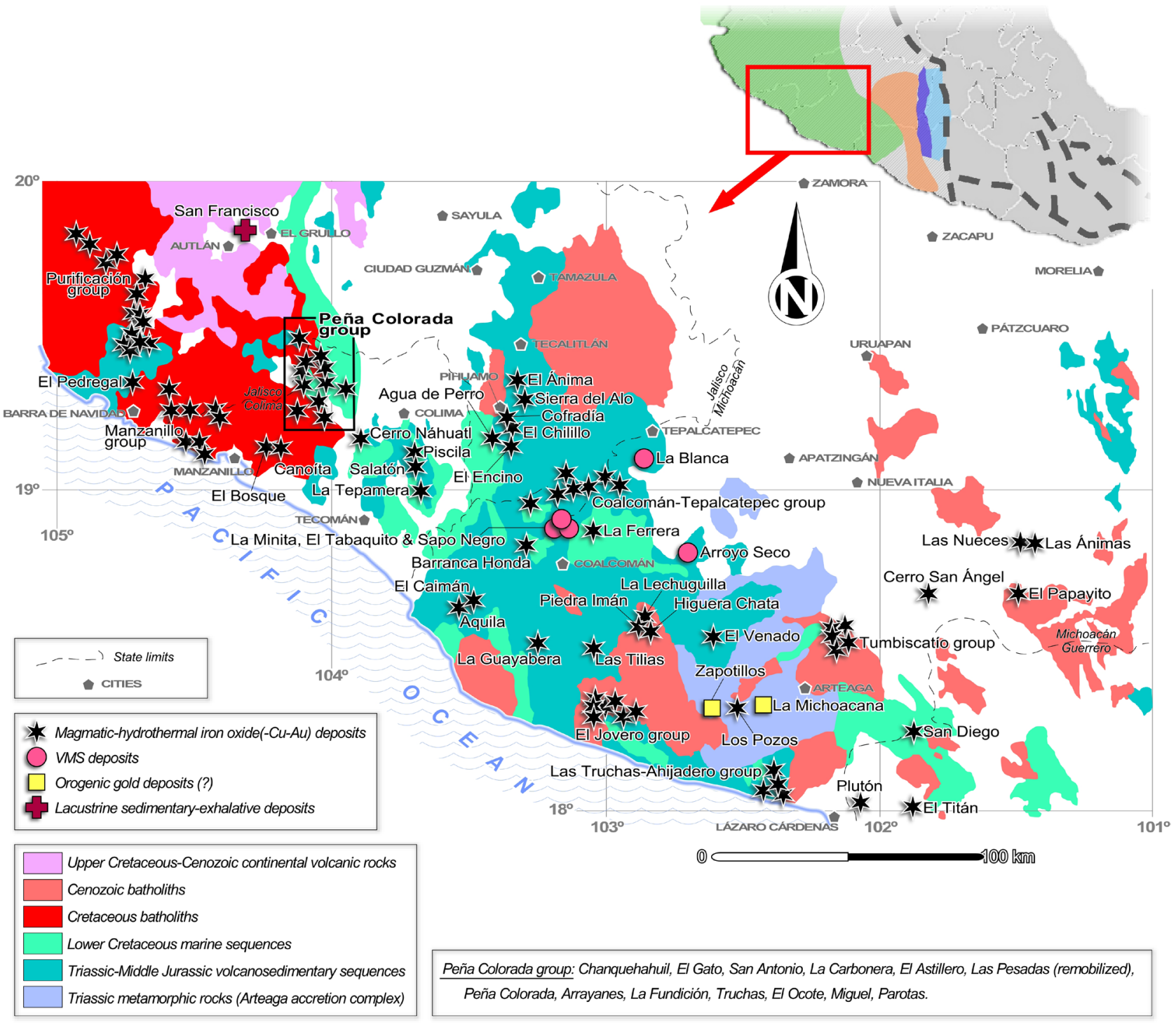

Figure 1 Regional distribution of ore deposits in southwestern Mexico, with the location of the mineralized region around the Peña Colorada deposit, Colima. Adapted from Camprubí and González-Partida (2017). 
The iron deposits in this district have been classified as magnetite-apatite Kiruna-type deposits based on their mineral parageneses (Klemic, 1970), despite having started as skarn-related deposits, which is the basic model of formation proposed by Zürcher et al. (2001). Such skarnrelated beginnings illustrate the nearness of these deposits to their magmatic origin.

These deposits are located in the western portion of the Zihuatanejo terrane, as part of the Guerrero composite terrane (Centeno-García et al., 2008). The Cretaceous stratigraphy in this region is characterized by drastic lateral facies changes, erosional nonconformities and wide variations in the thickness of stratigraphic units. Such dramatic changes were controlled by the distribution of volcanic edifices during the evolution of several volcanic arcs and of synvolcanic and synsedimentary faults. The ill-defined stratigraphy of the Zihuatanejo terrane consists, in the study area, of $\mathrm{a}>3000 \mathrm{~m}$ thick Cretaceous volcaniclastic and carbonate rock sequence, and a $>1000 \mathrm{~m}$ thick evaporite sequence. Calc-alkaline andesitic tuffs interbedded with carbonates (Tepalcatepec Formation) host most of the iron oxide deposits in the study area (Figure 2), and the overlying Cerro de la Vieja Formation (?) hosts part of the iron oxide deposits. The age of the Tepalcatepec Formation is considered to be Albian-Cenomanian based on its fossil content (Tritlla et al., 2003, and references within). Late Cretaceous dioritic rocks intruded the Cretaceous volcano-sedimentary assemblage and produced skarns and other skarn-like rocks. The magmatic rocks associated with the deposits belong either to the alkaline or calc-alkaline series, including rocks with tholeiitic affinity that correspond to a primitive arc (Zürcher et al., 2001; Corona-Esquivel and Henríquez, 2004). This mineralized area also includes several smaller deposits nearby, such as the Chanquehahuil,
Arrayanes, and La Fundición prospects (Figure 1). The intrusions in the Peña Colorada area that are closely related in space and time with iron oxide-apatite deposits include gabbros, diorites, and other hypabyssal rocks, and show complex interrelationships. These relationships include diorites either intruding or being intruded by felsic rocks, with millimeter- to decimeter-sized smoothly shaped blobs of one rock inside the other. Such gabbros and diorites contain magnetite both as a magmatic mineral and as a hydrothermal mineral accompanied by potassic and/or sodic alteration. A deep-seated diorite from Peña Colorada was dated at $67.6 \pm 3.5 \mathrm{Ma}$ (K-Ar, whole rock) by Sánchez-Quiroz and Juárez (1988). A gabbro (with tholeiitic affinity) that hosts most of the mineralization in the neighboring Arrayanes prospect was dated at $53.3 \pm 3 \mathrm{Ma}$ (K-Ar, K-feldspar) by Solé et al. (2007), which is virtually coeval to the main event of mineralization at Peña Colorada. Among other mined-out ore bodies at Peña Colorada, an intrusion of dioritic composition that contained up to $50 \%$ magnetite by volume (González-Reyna, 1956) stands as one of the likeliest candidates to be a "parental" intrusive to the ore deposits, or part of them.

Sound genetic studies in the Peña Colorada deposit have been carried out by Zürcher et al. (2001) and Tritlla et al. (2003), and additional genetic aspects were provided by Corona-Esquivel and Henríquez (2004) and Camprubí and Canet (2009). These studies provide evidence for links between magmatism, hydrothermal activity, and the formation of IOA deposits. However, key aspects of the mineralization deserve further attention: (1) ages of the stages of mineralization and a clear temporal sequence for all key geological aspects, (2) the association of mineralization with the structural evolution in the region and the structural framework for the emplacement of mineralized bodies, 


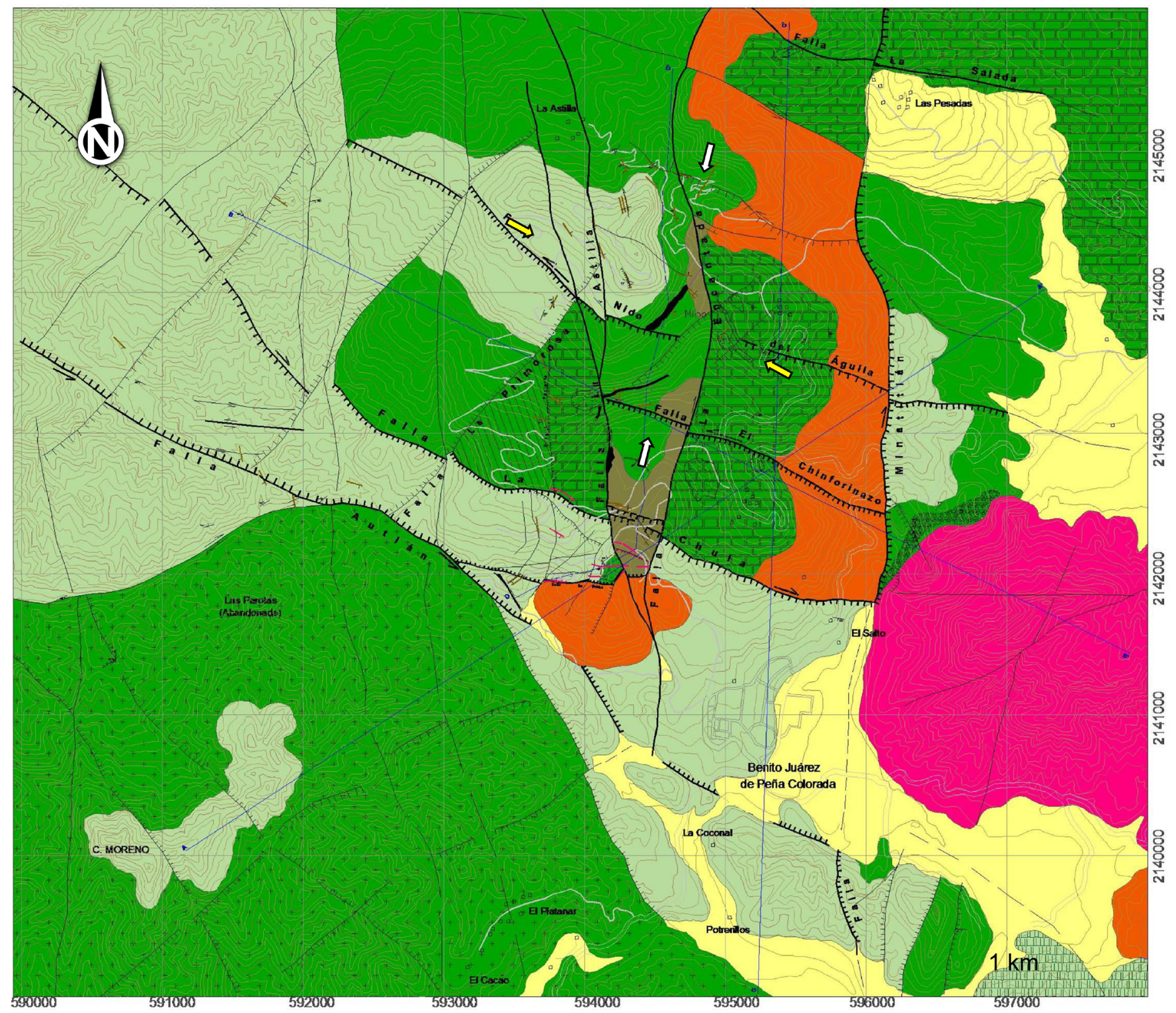

Alluvium

Cerro de la Vieja Fm (?)

Andesitic dikes

Monzonite

Diorite

Conglomerates and sandstones

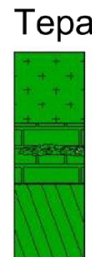

Magnetite deposits $\left[\begin{array}{l}\text { Polymictic breccia } \\ \text { Massive bodies } \\ \text { Disseminated bodies }\end{array}\right.$

Andesite flows

Tuffs and marly limestones

Sandstones, limolites and reef limestones

Figure 2 Geological map of the Peña Colorada deposit. For an idealized stratigraphic column of this deposit, see Zürcher et al. (2001). White arrows mark the position of the cross-section in Figure 5, and yellow arrows mark the cross-sections in Figure 18. 
and (3) the study of petrogenetically relevant compositions of major minerals in order to better constrain the genesis of these deposits.

\section{Zonation and mineralogy of the deposits}

\subsection{PEÑA GOLORADA}

The mineralization model of the Peña Colorada deposit is established as a multi-stage, skarn-related, magmatic-hydrothermal iron oxide-apatite (IOA) deposit, and thus it is a part of the IOCG "clan" of ore deposits (Zürcher et al., 2001; Tritlla et al., 2003; Camprubí and Canet, 2009; Camprubí and González-Partida, 2017). This deposit and the neighboring La Fundición prospect are enveloped by widespread potassic alteration (Figures $3 \mathrm{C}$ and D), particularly in the lower part of the deposit. Little sodic alteration, and conspicuous propylitic alteration occur in the upper part of the deposit. Potassic alteration is characterized by an assemblage of K-feldspar, ferroan chlorite (chamosite), apatite, magnetite, and accessory titanite, and can be found in other mineralized areas in the region, sometimes in close association with propylitic alteration laterally (Figure 3G). Sodic alteration is characterized by the occurrence of actinolite or albite. Propylitic alteration consists of epidote, ferroan chlorite, calcite, analcime, zeolites, and chalcedony or quartz. The various mineralization events in the Peña Colorada deposit display strong textural and structural differences. The most notorious mineralization styles are apparently stratabound massive and disseminated ore bodies
(Figure 3A) that are hosted by the volcano-sedimentary rocks of the Tepalcatepec Formation. The events that led to the formation of this deposit can be grouped as follows (Figures 4 and 5) and constitute a refinement that stems from Tritlla et al. (2003), Camprubí and Canet (2009), and Camprubí and González-Partida (2017):

1. intrusion of the Peña Colorada diorite,

2. barren stratabound skarn or other skarn-like rocks, not in direct contact with the diorite or other intrusive bodies,

3. syenite-like (due to pervasive potassic alteration) disseminated magnetite body with centimeter-sized K-feldspar,

4. disseminated 'stratabound' magnetite body (Figure 3C),

5. massive 'stratabound' magnetite body (coeval with the underlying disseminated body, see sections below) with associated massive magnetite veins, which contains garnetite fragments, with possible pyroxenes as well, that were completely replaced by potassic alteration assemblages (Figure 3D),

6. polymictic magnetite-rich breccia (Figure 3F), and other veins and veinlet arrays associated with this stage of mineralization,

7. intrusion of andesitic dikes with associated small barren skarn-like associations of garnets and pyroxenes.

The massive orebody is basically tabular, up to $40 \mathrm{~m}$ thick, over $1000 \mathrm{~m}$ long, and nearly parallel to the local layering of host andesite flows and carbonate rocks, which confers to this orebody an apparent stratabound character (see section 3 for further clarification). It is closely associated with meter-sized, equally massive, subvertical veins.

Figure 3 Selected aspects of the magmatic-hydrothermal iron oxide mineralized areas in the Peña Colorada region, Colima. (A) Landscape view of the main mineralized bodies in the Peña Colorada mine, partially stratabound through volcano-sedimentary rocks of the Tepalcatepec Formation. (B) Sodic alteration (actinolite) accompanying magnetite in veins cutting gabbro in the Arrayanes area. (C) Disseminated magnetite mineralization associated with potassic alteration in the lower disseminated body in Peña Colorada, with potassium feldspar-rich (pink) and ferroan chlorite-rich (green) seams. (D) Potassic alteration in fragments of garnetite engulfed by the massive magnetite body in Peña Colorada (potassium feldspar + chlorite + apatite + magnetite pseudomorphs after garnet). (E) Hematite replaced by magnetite ("mushketovite") in the La Fundición area. (F) Breccia fragment or "xenolith" constituted by magnetite + apatite + pyroxene in magnetite matrix from the lowermost exposed portion of the polymictic breccia in Peña Colorada. (G) Garnetite replaced by epidote-rich (partial replacement) and potassic alteration (complete replacement) assemblages in the La Fundición area. Photos C, D, and F appeared in Tritlla et al. (2003), and are reproduced with permission. 

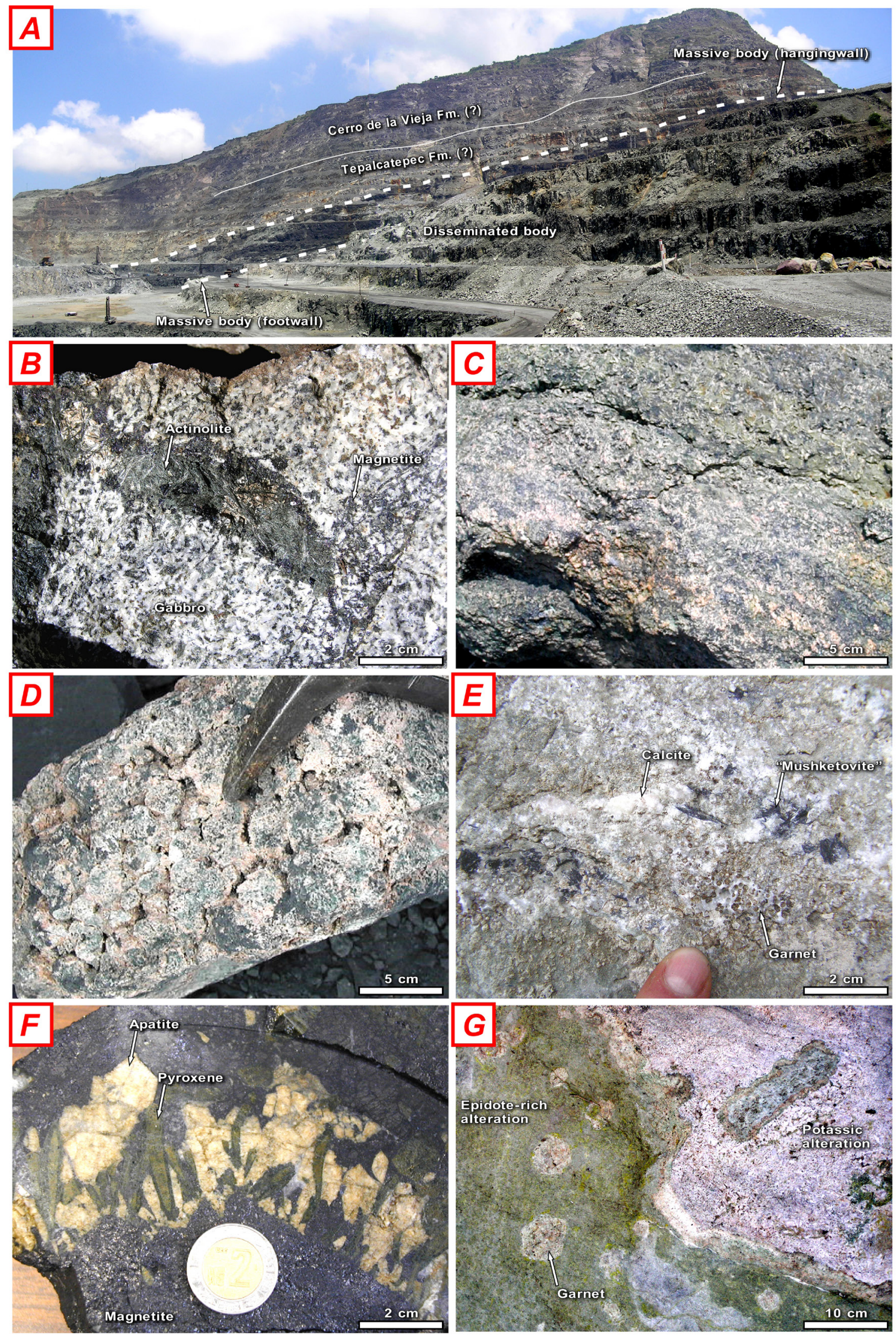
The mineralogy of this orebody is dominated ( $>85 \%$ in volume) by subhedral to euhedral magnetite (Figures 6A and D), either replacing earlier hematite (or "mushketovite"; Figure 6B) or partially martitized (Figures $6 \mathrm{C}$ and D), with subordinate pyrite, chalcopyrite, pyrrhotite, potassium feldspar, diopside (see section 4 in this paper), chlorite, fluorapatite, titanite, calcite, siderite, albite, and actinolite. Not all "primary" hematite has been replaced by magnetite (Figure 6D). Potassium feldspar is an early mineral in the massive associations, either intergrown with ferroan chlorite or slightly postdated by it (Figures $6 \mathrm{C}$ and $\mathrm{D}$ ), and both are later engulfed by magnetite (Figure 6A) or, in the upper part of the deposit, by hematite (Figure 6D). Fragments of feldspathic rocks

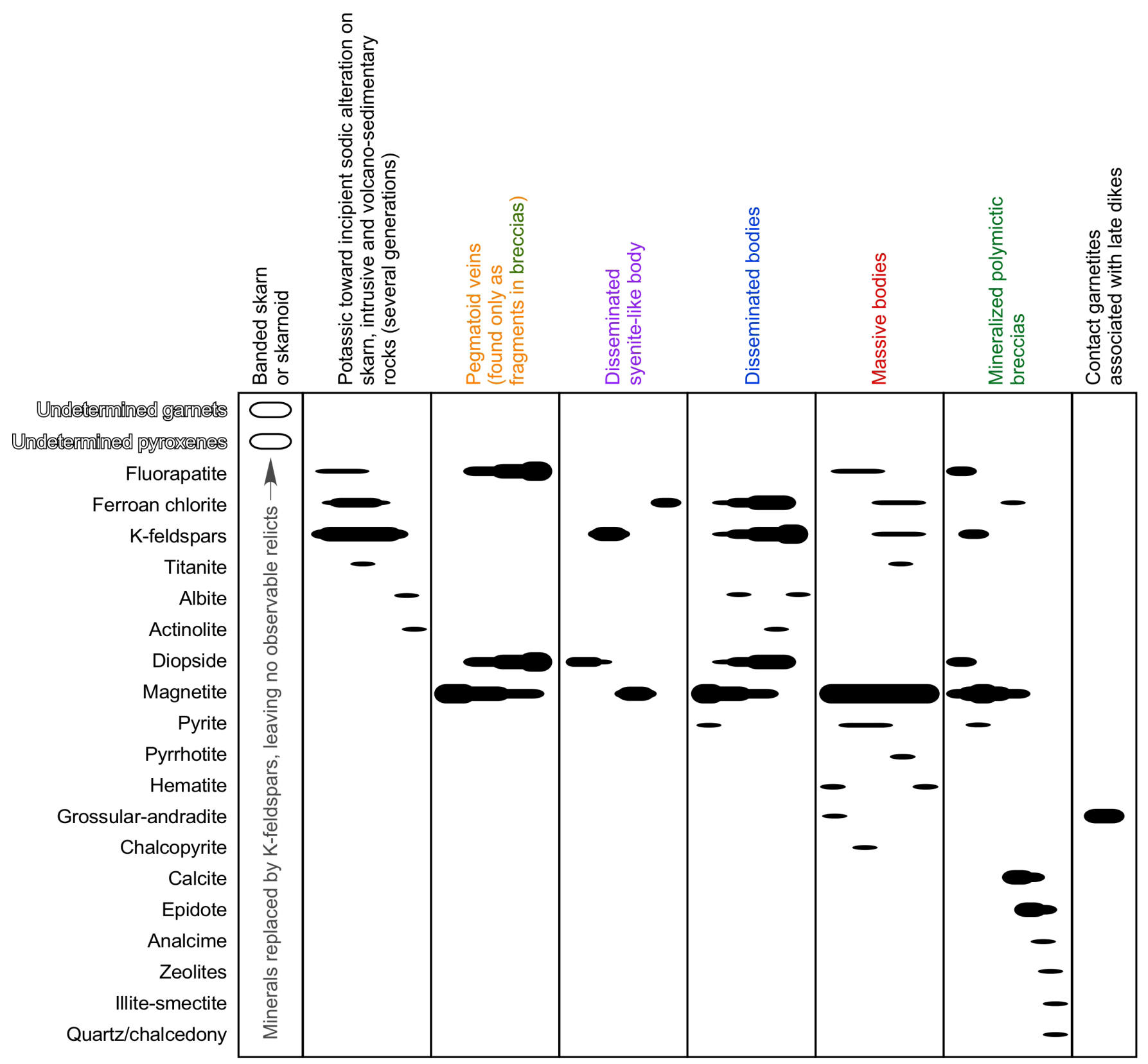

Figure 4 Paragenetic sequence and mineralization events for the Peña Colorada magmatic-hydrothermal iron oxide deposit, as determined in this study. 


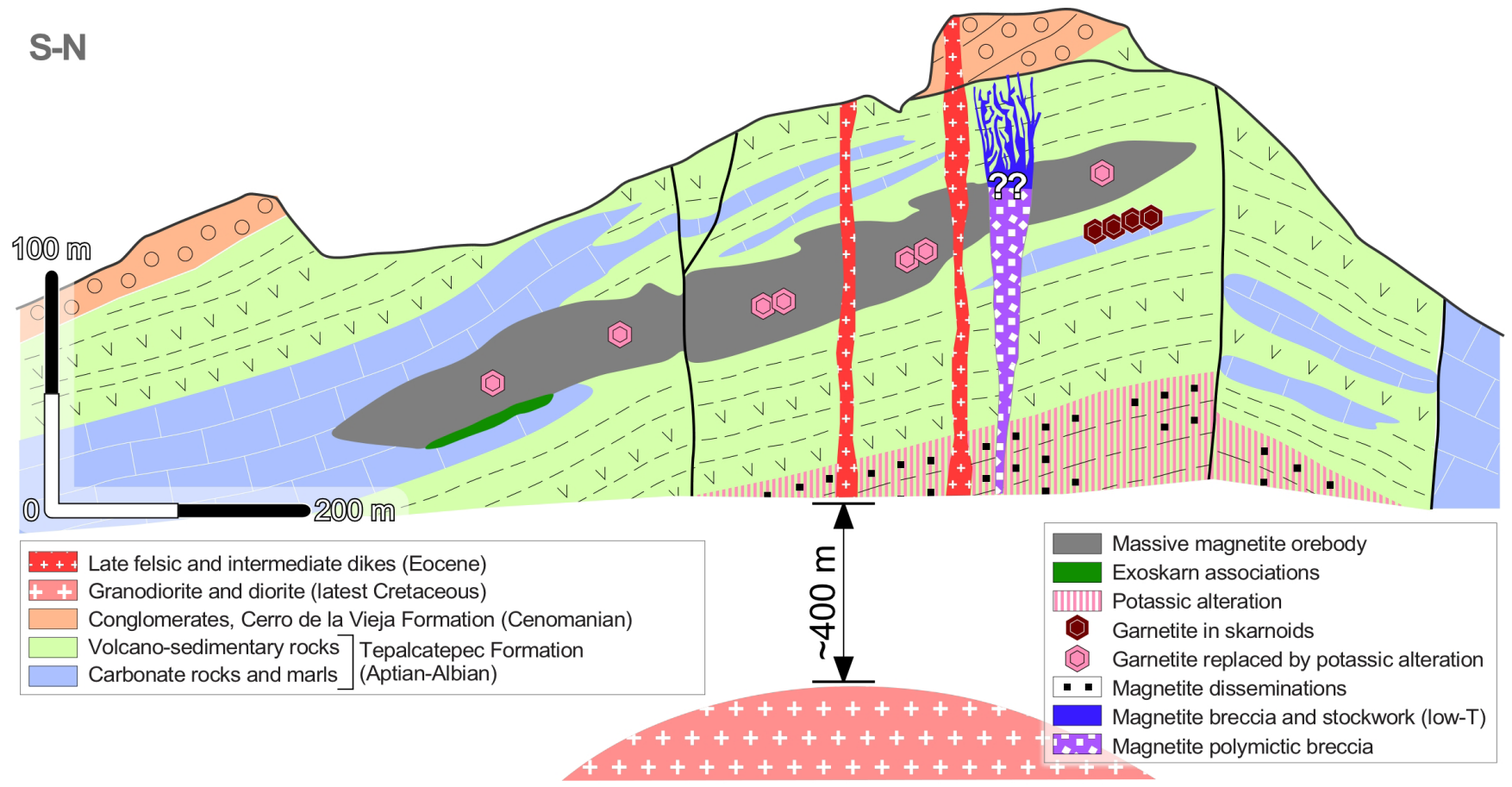

Figure 5 Idealized cross-section of the Peña Colorada deposit showing the geometry of the ore bodies. End point locations are indicated by white arrows on Figure 2. Amended and simplified from Tritlla et al. (2003) and Camprubí and González-Partida (2017).

are found sporadically in the massive orebody, which resulted from the complete replacement of pre-existing garnetites (with garnet and pyroxene from earlier skarn or skarnoid associations), and constitute evidence for potassic alteration in close association with this stage of mineralization (Figures $3 \mathrm{D}$ and $6 \mathrm{~F})$. Ferroan chlorite is intimately associated with feathery potassium feldspar in such associations (figure 6a in Tritlla et al., 2003) plus minor fluorapatite and magnetite (Figure 6F) and accessory titanite. Centimeter-sized bands of calcium silicates are formed at the contact between carbonate and volcano-sedimentary rocks and between limestones and the massive magnetite body (see figure 4a in Tritlla et al., 2003), and even variable degrees of recrystallization (marble) can be found within limestones. However, such manifestations consist of microgranular aggregates that form decimeter-sized bands.

The disseminated orebody is found 80 to $100 \mathrm{~m}$ below the massive orebody, is over $60 \mathrm{~m}$ thick, and its hanging wall is apparently subconcordant to the local layering of the host andesitic rocks.
This orebody has reserves of approximately 150 Mt grading 26\% magnetite. It shows a laminated internal arrangement derived from a volcanosedimentary protolith (Tepalcatepec Formation) replaced by associations with dominant magnetite, potassium feldspar, ferroan chlorite, diopside, apatite, and pyrite in pseudo-layered seams (Figures $3 \mathrm{C}$, and $6 \mathrm{G}$ and $\mathrm{H}$ ). Diopside is an early mineral in the disseminated associations (Figure $6 \mathrm{H}$ ), and it is later engulfed by a close association between potassium feldspar, ferroan chlorite, and fluorapatite (Figure $6 \mathrm{H}$ ), and later magnetite (Figure 6G). Laterally to the disseminated pseudo-layered deposits are accumulations euhedral to anhedral, non-orientated potassium feldspar crystals (similar to a syenite) that poikilitically enclose euhedral to subhedral magnetite. These associations form irregular bodies that extend for several meters. Their mineralogy is essentially the same as in the disseminated body (Figure 6L). Such accumulations may represent portions of deeper bodies that were upthrown by faulting, as the occurrences of this orebody are entirely limited by faults. As 

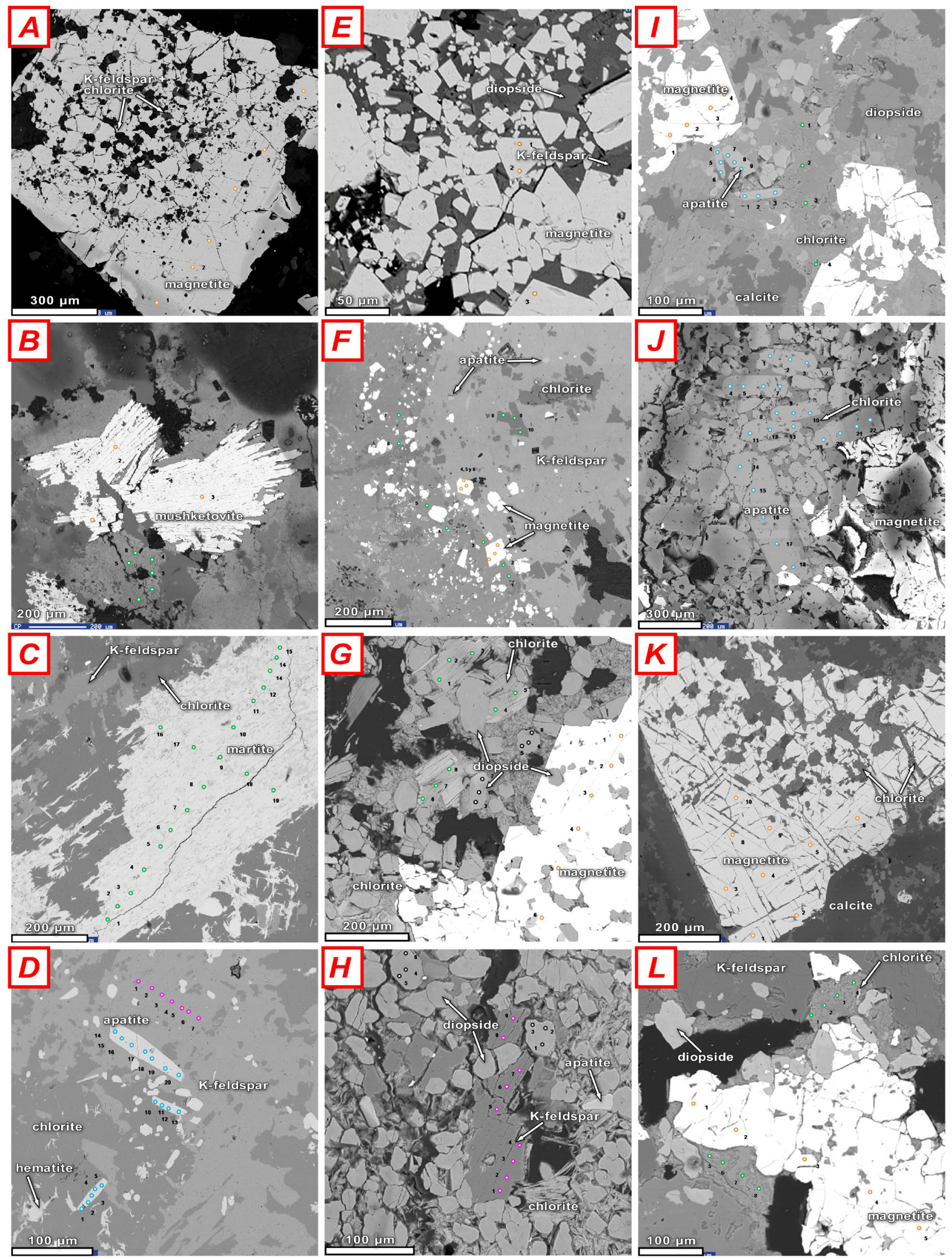
these are the only available outcrops of this body, neither its size, shape, depth, strike, or iron grade are known.

The disseminated and massive bodies are dubbed "semi-stratabound" despite looking stratabound because their emplacement is not entirely controlled by local stratigraphy. As explained in section 4, the position of such bodies is related to low-angle Laramide faulting, but they can be considered partially stratabound because the volcanosedimentary sequence favors the emplacement of orebodies as much as limestones seemingly preclude it. Such a favorable characteristic of the volcano-sedimentary sequence is possibly due to the original porosity and permeability of the rocks, which were enhanced by a high concentration of fracturing. Fracture density is visibly higher in volcano-sedimentary rocks than in carbonate limestones.

The polymictic breccia is a subvertical zone of brecciation that cuts the massive and disseminated bodies and its shape cannot be easily described as a vein (see its basal shape on the surface in Figure 2), which led Tritlla et al. (2003) to describe it tentatively as a diatreme. The structure, morphology, and mineralogy of this breccia are highly variable through its vertical extent. It can be approximately $5 \mathrm{~m}$ wide in its lower part, where it contains sharp-edged andesite blocks in a fine-grained magnetite matrix that resembles a breccia formed by hydraulic fracturing. Other fragments, up to $1 \mathrm{~m}$ in diameter, are made up of aggregates of centimeter-sized crystals of magnetite, fluorapatite, and diopside (Figure 3F). Such fragments are interpreted as "xenoliths" from deeper pegmatoid veins that do not crop out nor were reached by drilling at Peña Colorada. The general mineralogy of the breccia, both in the matrix and clasts, is constituted by magnetite, diopside, apatite, ferroan chlorite, and potassium feldspars (Figure 6I to K). Magnetite crystals are generally euhedral to subhedral and show corrosion bays occupied by ferroan chlorite, normally along structural weakness planes (Figure 6I and $\mathrm{K}$ ); the occurrence of ferroan chlorite is typically late (Figure $6 \mathrm{~J}$ ). In the central section of the deposit, the breccia is $>10$ $\mathrm{m}$ thick, > $100 \mathrm{~m}$ long, and contains (1) magnetite blocks from the massive body; (2) fragments of underlying host aplites and andesites that are overgrown by coarse magnetite crystals and affected by potassic alteration assemblages; (3) fragments of barren host volcano-sedimentary rocks, also with overprinted potassic alteration; and (4) fragments from the disseminated body. An array of crustiform veinlets are found in the polymictic breccia and extend into the upper part of the deposit and can be found laterally for a few hundreds of meters. Some of these can also be found around

Figure 6 Back-scattered electron images of representative textures in the main stages of mineralization in the Peña Colorada deposit: massive (A to F), disseminated (G and H), late polymictic breccia (I to K), and early syenite-like body (L). (A) Single subhedral magnetite crystal with a late association of chlorite and potassium feldspar in corrosion bays or along microfractures. (B) Hematite replaced by magnetite (or "mushketovite") in a matrix of intergrown chlorite and potassium feldspar. (C) Magnetite replaced by hematite (or "martite") that grew beyond the original borders of magnetite crystals extended into cleavage plane of earlier chlorite intergrown with potassium feldspar. (D) Association of potassium feldspar, chlorite, apatite, and late hematite in the upper part of the massive body. (E) Euhedral magnetite crystals with interstitial potassium feldspar and diopside. (F) Garnet crystal replaced by an association of potassium feldspar, chlorite, magnetite, and small apatite crystals, in a groundmass richer in magnetite and chlorite. Notice the sharp contact between the garnet pseudomorph and the groundmass; this is part of a feldspathized garnetite fragment within the massive body. (G) Subhedral magnetite engulfing diopside and chlorite. (H) Association of potassium feldspar, diopside, chlorite, apatite, and late tiny magnetite crystals. (I) Association of euhedral magnetite and apatite crystals where magnetite was largely corroded and replaced by an association of diopside and chlorite with late calcite in the upper part of the breccia. (J) Association of magnetite and apatite with late chlorite lining the remaining intercrystalline spaces, in the lower part of the breccia. (K) Large euhedral magnetite crystal with an association of chlorite and calcite in corrosion bays and along microfractures in magnetite, in the lower part of the breccia. (L) Intergrowths of magnetite, potassium feldspar, and diopside, with late chlorite. The gangue mineralogy that accompanies all ore associations in the massive and disseminated bodies in this deposit denotes potassic alteration with later sodic-calcic alteration (see figure $6 \mathrm{~h}$ in Tritlla et al., 2003). All numbered colored dots in the pictures denote the positions of EPMA analyses. Chlorite compositions in all associations correspond to chamosite. 
the breccia at its lowermost portions. Such veinlets contain magnetite, fluorapatite, calcite, ferroan chlorite, zeolites, prehnite, scapolite, chalcedony, and quartz, and are associated with extensive propylitic alteration assemblages that contain epidote, ferroan chlorite, and calcite. Epidote can be found as pseudomorphs of unidentified pyroxenes from earlier mineral associations (skarnoids?). A partial replacement of clasts of conglomerates in the Cerro de la Vieja Formation on top of the host volcano-sedimentary sequence of the Tepalcatepec Formation is thought to be coeval with such hydrothermal veinlets because it is the only mineralized body that seemingly reached the conglomerates.

Zürcher et al. (2001) described the occurrence of delafossite, chalcocite, covellite, and manganese oxides as supergene minerals. For further details in the petrographic characterization of the above mineral associations and their mineral chemistry, see Zürcher et al. (2001) and Tritlla et al. (2003).

\subsection{ARRAYANES AREA}

In the Arrayanes prospect, sodic alteration (dominated by actinolite with muscovite; Figure 3B) covers several square kilometers with poorly developed potassic alteration (dominated by potassium feldspar or biotite) along magnetite-diopside stringers, and scarce propylitic and phyllic alteration assemblages. This alteration framework is the opposite situation to the one found in the Peña Colorada deposit. Alteration assemblages at Arrayanes were developed in gabbros, microgranodiorites, diorites, andesites, and trachytes (the latter two as part of the Cretaceous volcano-sedimentary sequence). Gabbros in the area (named Llanitos gabbro by Corona-Esquivel and Henríquez, 2004) are abundant and contain magmatic magnetite, as do diorites and microgranodiorites to a lesser extent. Gabbros and diorites show complex interrelations that suggest emplacement together as part of the same intrusive body. Both rocks (1) seem to be intruding each other, (2) have gradational contacts, or (3) have centimeter- to decimeter-sized angular to rounded fragments of one rock enclosed in the other, particularly near their contact. This makes a persuading case for magma mixing or mingling. The complex contacts between gabbros and diorites may display unevenly distributed and irregularly shaped magnetite-rich bands, especially in case 3 above. All these intrusive rocks contain disseminated magnetite (with higher contents in gabbro and diorite than in microgranodiorite) even in areas where no hydrothermal alteration was observed. The Llanitos gabbro has a sound tholeiitic affinity, whereas most hypabyssal rocks in the region are calc-alkaline (Corona-Esquivel and Henríquez, 2004). In this sense, Zürcher et al. (2001) described the intrusive rocks in the region as formed in a primitive arc with both tholeiitic and calc-alkaline affinities.

Sodic alteration is characterized by actinolite, muscovite, magnetite, ferroan chlorite, pyrite, and albite (Figure 7), and sometimes occurs as essentially monomineralic actinolite veinlets. Potassic alteration assemblages in this area are characterized by the occurrence of potassium feldspar and/or biotite, and include titanite, magnetite, pyrite, diopside, and muscovite in various amounts. These may also occur as veinlets in which potassium feldspar, magnetite, and diopside are the dominant minerals. Unlike the case of Peña Colorada, it is not common that potassic alteration assemblages obliterate the original magmatic features. When incipiently developed, potassic alteration advances through penetrative microfractures and may generate some pseudobanding with unaltered magmatic minerals. Even with little progress, potassic alteration may rapidly induce the complete replacement of host rocks. Phyllic alteration assemblages are relatively scarce and are constituted by "sericite" (essentially, finegrained muscovite), quartz, pyrite, magnetite, and accessory actinolite. Propylitic alteration is closely associated with potassic alteration, and is constituted by ferroan chlorite, actinolite, "sericite." quartz, pyrite, magnetite, and accessory calcite and epidote. 
The relatively weak development of alteration assemblages in the Arrayanes prospect (in comparison with the Peña Colorada deposit) allows to better identify the presence of magmatic magnetite in hypabyssal rocks. It follows that the amount of disseminated magnetite (roughly estimated by hand magnet in the field) in gabbros, diorites, or microgranodiorites is seemingly independent of the intensity or penetrativity of hydrothermal alteration assemblages nearby, although magnetite increases in areas with potassic alteration assemblages. However, the relative amount of magnetite in association with potassic alteration assemblages is highly variable, between feldspathization stripes that sandwich magnetite-rich cores and highly developed potassic assemblages with little disseminated magnetite. Despite the leap in scale that this implies, this is analogous to the Peña Colorada deposit, in which magnetite contents in potassic alteration show extreme variations down to null in

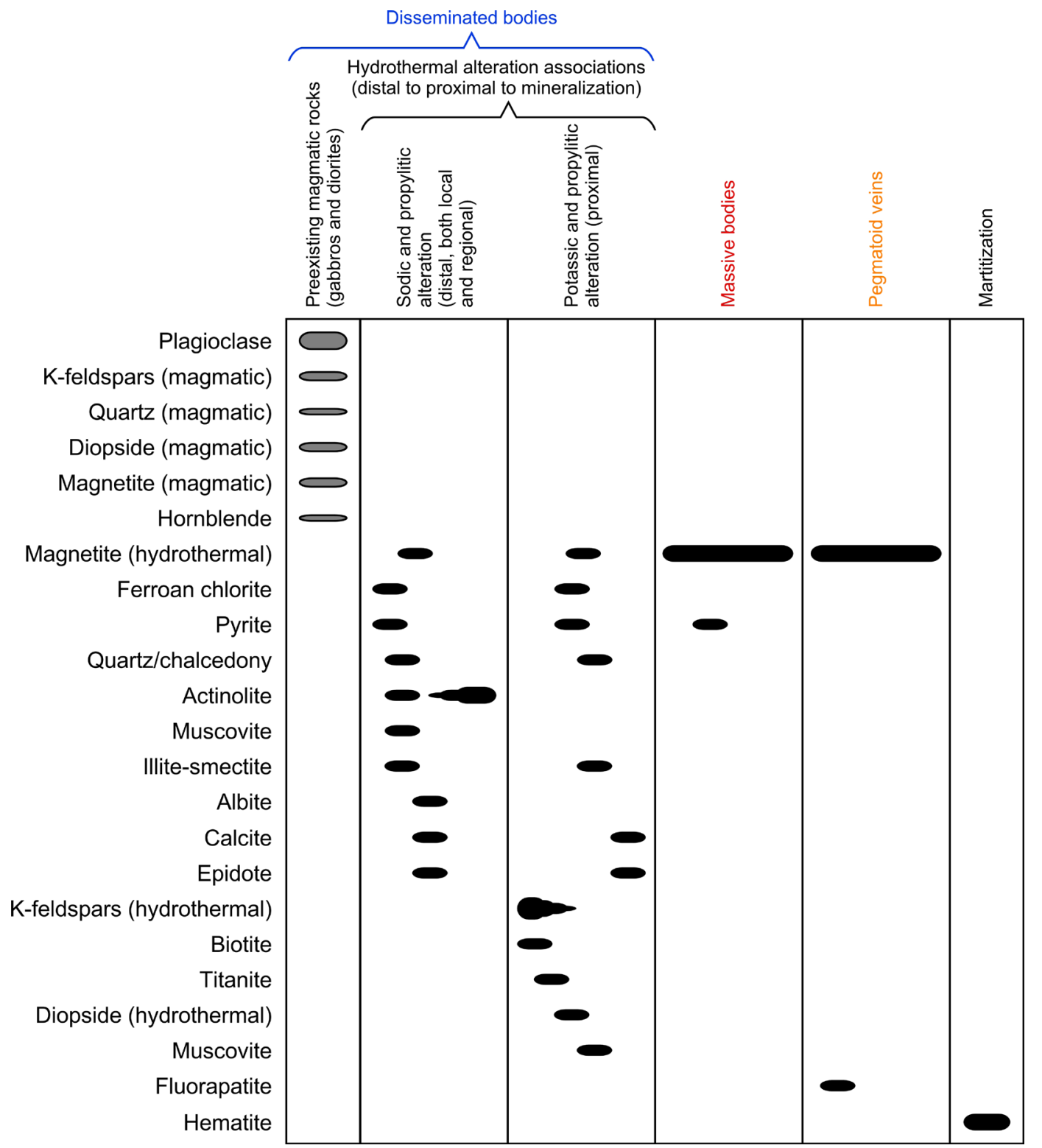

Figure 7 Paragenetic sequence and mineralization events for the magmatic-hydrothermal iron oxide deposits in the Arrayanes area, as determined in this study. 
potassic alteration around the polymictic breccia. Similar to Peña Colorada, the Arrayanes prospect is surrounded by large areas with disseminated magnetite, but also exhibits meter-sized, massive, nearly horizontal bodies and veins, plus "pegmatoid" magnetite plus fluorapatite veins (Figure 7). The latter show a striking similarity with the magnetite plus fluorapatite plus diopside "xenoliths" in the polymictic breccia at Peña Colorada, which seemingly occur as a late stage of mineralization in the Arrayanes prospect. However, limited exposure does not permit detailed descriptions or interpretations of the extent and relative temporal arrangement of the mineralized bodies at Arrayanes. For instance, besides the occurrence of disseminated magmatic magnetite in hypabyssal bodies, the possible association between disseminated magnetite of hydrothermal origin and massive bodies is uncertain. Only magnetite plus fluorapatite veins seemingly postdate the disseminated and massive bodies. Iron oxide mineralization in Arrayanes seem to occur in association with WNW-ESE faulting alone. This is an important feature because the main mineralization event in the Peña Colorada deposit (massive and disseminated bodies) is also associated with WNW-ESE faulting, although other mineralized events in this deposit are associated with other structural domains (discussed below), unlike the Arrayanes prospect.

\section{Structural analysis}

\subsection{REGIONAL ANALYSIS}

The Peña Colorada deposit and the Arrayanes prospect are found in horsts that formed to the west and east, respectively, of the NE-SW striking Minatitlán Graben, and both are limited to the south by the regional WNW-ESE Autlán Fault (Figures 8 and 9A). The regional rosette (Figure 8, inset) shows concentration peaks for five structural domains that strike $\mathrm{N}-\mathrm{S}$, NNW-SSE, NW-SE, $\mathrm{E}-\mathrm{W}$, and NE-SW. The highest concentration of alignments corresponds to NE-SW strikes, then NW-SE, NNW-SSE and E-W strikes, and finally $\mathrm{N}-\mathrm{S}$ strikes. Both the concentration of alignments and the continuity/discontinuity of structures constitute qualitative criteria for assessing the relative timing of structures. The oldest structural domains correspond to $\mathrm{N}-\mathrm{S}$ and NNW-SSE strikes, and these show lower concentrations than the rest, as defined by their length. It is likely that their distribution was altered by later structures by means of linear or rotational displacements, thus limiting their strike length. Further, N-S and NNW-SSE structures were reactivated at least once and they have induced displacements of later structures during such reactivation(s), which added complexity to the already intricate structural pattern; such is the case of the La Encantada fault in the Peña Colorada mine. Zürcher et al. (2001) stated that the oldest structures at Peña Colorada strike $\mathrm{N}-\mathrm{S}$, a finding we corroborated by detailed structural analysis and by photointerpretation. The NW-SE structural domain is continuous in its strike length, and displays a high frequency in the rosette (Figure 8).

The relative chronology determined by crosscutting relations among structures in the Arrayanes and Peña Colorada areas (see section below) and their distribution in the digital elevation model indicate that NW-SE structures were long-lived and postdate $\mathrm{N}-\mathrm{S}$ and NNW-SSE domains. The NW-SE domain comprises the Autlán, La Chula, and Nido del Águila faults. These faults are kinematically complex, with an essentially sinistral strike-slip motion as the latest recorded activity. The E-W structural domain occurred next; its strike length is limited by pre-existing structures. The last one is the NE-SW structural domain, which shows the highest concentration in the rosette and crosscuts all pre-existing structures. This domain recorded intermittent motion to the point that some of its structures may still be active, as suggested by the occurrence of near-surface epicenters in this region with the same strike (Garduño-Monroy et al., 1998). The NE-SW domain controlled the local horst-and-graben arrangement 
between the Peña Colorada and Arrayanes areas (Figure 8). The Peña Colorada deposit is found in an ancillary horst within the NE-SW striking Manzanillo graben, whose northeastern limit is the ancillary Minatitlán graben. East from this graben there is the Manzanillo horst, which contains the Arrayanes mineralized area (Figure 8). Both the Manzanillo horst and the Manzanillo graben are terminated to the northeast by the Las Cumbres fault zone, with no precise age but described as a basement discontinuity (Bandy et al., 2005). In the study area, the fault zone is found on the southwestern shoulder of the Manantlán range, which represents the northwestern end of this fault zone. The Las Cumbres fault zone strikes dominantly NW-SE and, besides truncating the NE-SW striking Manzanillo horst-and-graben ensemble to the south, it also truncates a N-S striking fault system to the north (Bandy et al., 2005). Another regional fault that resulted from a basement discontinuity is the long-lived, $>160 \mathrm{~km}$-long Tamazula fault zone; it is part of the NE-SW structural domain

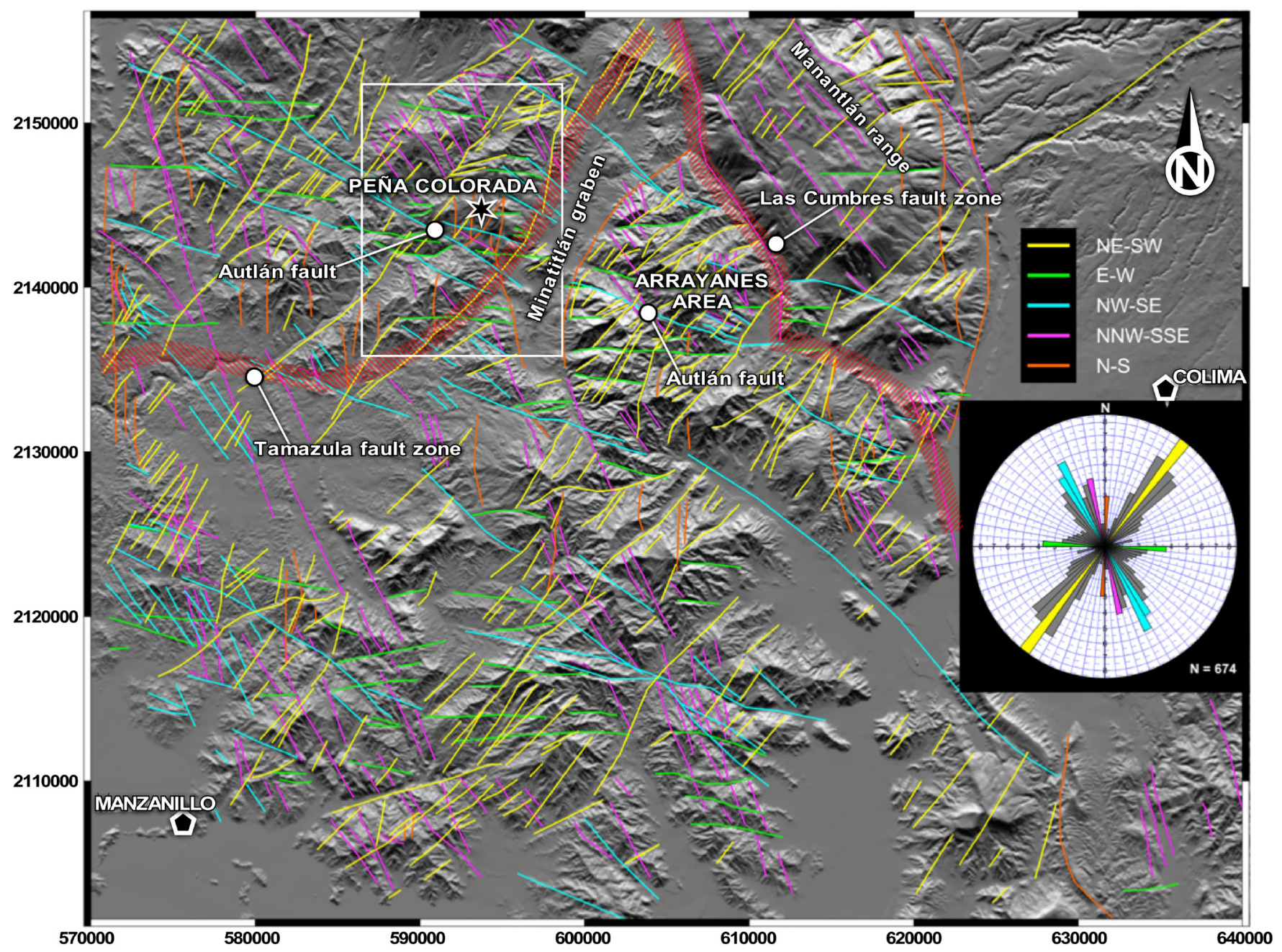

Figure 8 Digital model for the western part of the state of Colima in SW Mexico showing the main structural traits and classification by color upon their preferential strike in five domains. The structural distribution in the region is illustrated in the rosette inset, which is weighted considering the total strike lengths of each structural domain in the digital model. The white rectangle corresponds to the area analyzed in Figure 9. 
and controlled the motion of similarly striking structures in the region as well as in the Colima volcanic complex (Garduño-Monroy et al., 1998).

\subsection{LOGAL ANALYSIS}

Local structural domains are in good agreement with the regional ones (Figure 9A). First-order structures in the Peña Colorada area are the Minatitlán, Autlán (also named Jala), La Encantada, El Mamey, Nido del Águila, and La Chula faults (Figure 9B). These semi-regional to regional faults have associated second-order faults that controlled the emplacement of mineralized bodies in the Peña Colorada deposit. The ancillary Peña Colorada horst is crosscut by several second-order structures that strike WNW-ESE (e.g., Falla Nido del Águila fault) and NE-SW (e.g. , Poniente fault) and induce the displacement of the whole Mesozoic volcano-sedimentary sequence as well as the mineralized bodies. Five domains were identified in the Peña Colorada area, with the following distribution in time: (1) N-S to NNW-SSE, (2) WNW-ESE, (3) E-W, (4) WNW-ESE to NW-SE, and (5) NE-SW (Figure 9C), although some of them have experienced some reactivation (most notably, WNW-ESE structures). A relative timing of all geologic events is established by "shuffling" such structural domains with the different events of intrusion and/or mineralization in the Peña Colorada deposit by means of their crosscutting relations (Figure 9G). Such structural patterns are also found at the Arrayanes prospect. Earlier low-angle shortening structures likely formed during the Laramide orogeny and are restricted to the Mesozoic volcano-sedimentary sequence, thus predating all events of iron oxide mineralization. Such structures exerted some control on the mineralization nonetheless as they formed zones of weakness that worked as passive channelways for ore-forming hydrothermal fluids. The massive orebody, which would seem to follow stratification within the volcano-sedimentary rocks in the sequence (Figures 3A and 5), actually follows low-angle shortening structures that dip slightly steeper than the stratification. The dominant post-Laramide structural features are high-angle normal and strike-slip faults where dikes and veins were emplaced. These have three main finite maximum-extension strikes: (a) $\mathrm{N} 10^{\circ} \mathrm{E}-\mathrm{S} 10^{\circ} \mathrm{W}$, with E-striking normal faults and dikes, mostly monzonitic; (b) $\mathrm{N} 70^{\circ} \mathrm{E}-\mathrm{S} 70^{\circ} \mathrm{W}$, with $\mathrm{NNW}$-striking faults that control the emplacement of andesite dikes and calcite plus epidote veins (associated with the

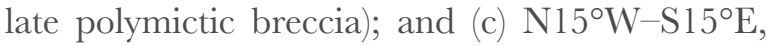
which coincides with the regional NE-SW- and ENE-WSW-striking horst-and-graben configuration. Most high-angle structures were reactivated several times; recent strike-slip faulting strikes $\mathrm{E}-\mathrm{W}, \mathrm{N} 00^{\circ} \mathrm{E}$ to $\mathrm{N} 20^{\circ} \mathrm{E}$, and $\mathrm{N} 20^{\circ} \mathrm{W}$ to $\mathrm{N} 40^{\circ} \mathrm{W}$ for dextral faults, and $\mathrm{N} 00^{\circ} \mathrm{W}$ to $\mathrm{N} 20^{\circ} \mathrm{W}, \mathrm{N} 40^{\circ} \mathrm{E}$ to $\mathrm{N} 60^{\circ} \mathrm{E}$, and $\mathrm{E}-\mathrm{W}$ for sinistral faults.

The N-S to NNW-SSE structural system in the study area, besides exerting a direct control on the emplacement of part of the mineralization, confined the eastward and westward lateral extensions of the massive iron oxide body through Laramide low-angle faults. Thus, ore-forming fluids found the most efficient channelways between the La Encantada and Poniente-La Astilla N-S faults. Therefore, these faults did not cut the ore bodies. The $\mathrm{N}-\mathrm{S}$ system is the third in structural concentration in the area (Figure 9, inset); its weighted length is low due to drastic lowering by later fault domains, although the $\mathrm{N}-\mathrm{S}$ system was largely associated with the reactivation of discontinuities in the local basement, hence the initially discrete character of its structures. Kinematically, this system has a dominant strike-slip movement that is sinistral in the western termination of the mineralized area, and dextral in the east. This generated an ancillary horst in the southernmost part of the area (La Chula). The distribution of $\mathrm{N}-\mathrm{S}$ structures in the different lithologic units in the area allows recognition of a time gap between the Tepalcatepec and Cerro de la Vieja formations (Figure 10), which implies that the N-S system is older than the Cerro de la Vieja Formation. Younger lithologic units or orebodies also show $\mathrm{N}-\mathrm{S}$ to NNW-SSE structures, which indicate 

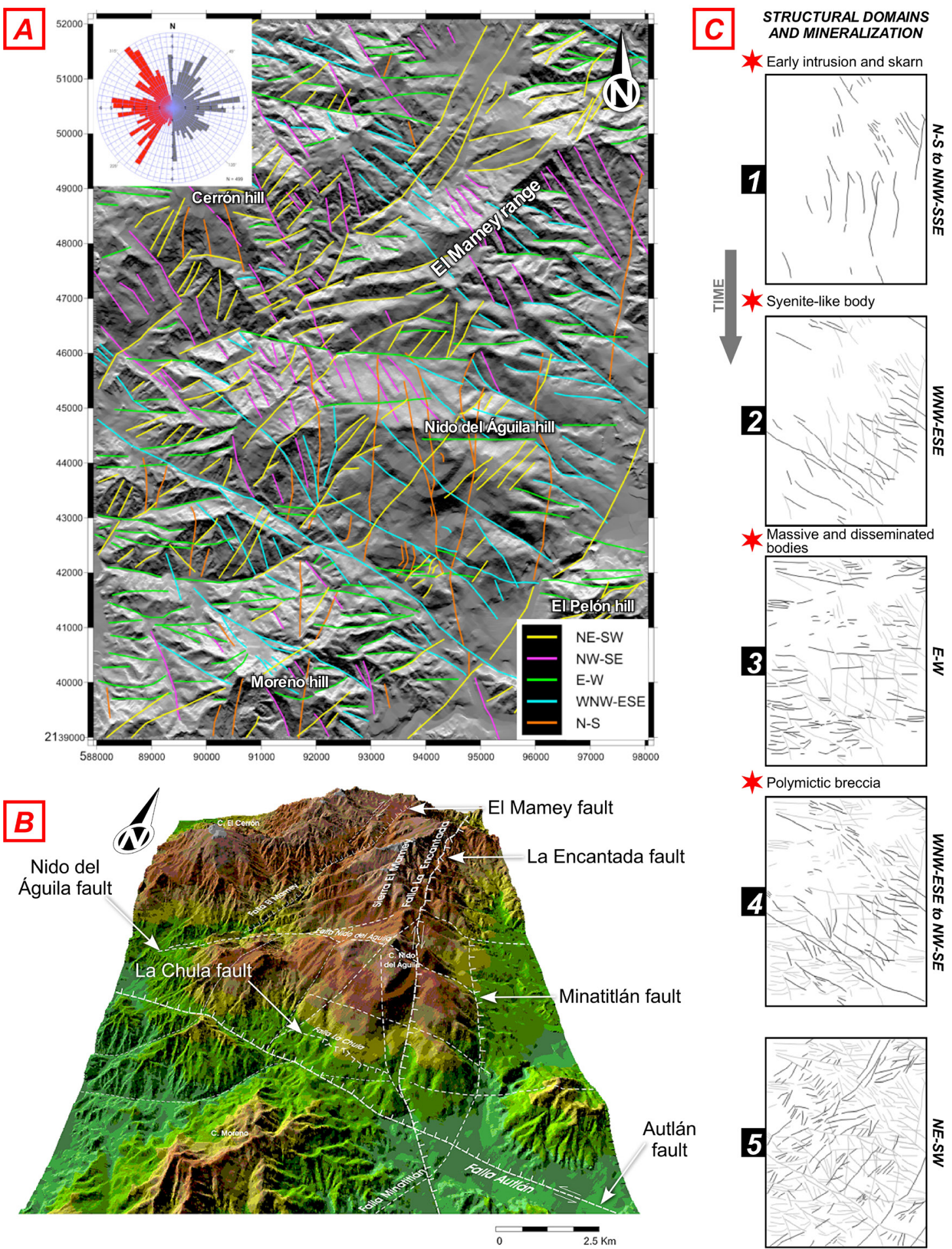

Figure 9 Local digital models for the surroundings of the Peña Colorada mine. (A) Digital model showing the five structural domains in the area, with two rosettes (upper left) for the identified structural alignments: non-weighted in gray, and weighted considering the total strike lengths of each structural domain in red. (B) 3-D digital model with the largest structural traits in the Peña Colorada deposit. The slight blurriness in the central area in (A) and (B) is due to the mining operations in the Peña Colorada mine. (C) Time sequence of the five structural domains identified in the Peña Colorada area: (1) N-S, (2) WNW-ESE, (3) E-W, (4) NW-SE, and (5) NE-SW. Red stars correspond to mineralization events in the iron oxide deposit. The NW-SE Autlán fault forms a semi-regional structural trait with which the Arrayanes mineralized area is associated as well, although it is dissected by the structures that form the Minatitlán graben (see Figure 8). 
reactivation that allowed the emplacement of andesite porphyry dikes and calcite + epidote + chlorite + apatite + magnetite veins associated with the polymictic breccia along a $\mathrm{N} 70^{\circ} \mathrm{E}-\mathrm{S} 70^{\circ}$ extension (Figure 10).

The WNW-ESE structural domain encloses the Peña Colorada mineralized area on its northern and southern limits, and consists of transtensive
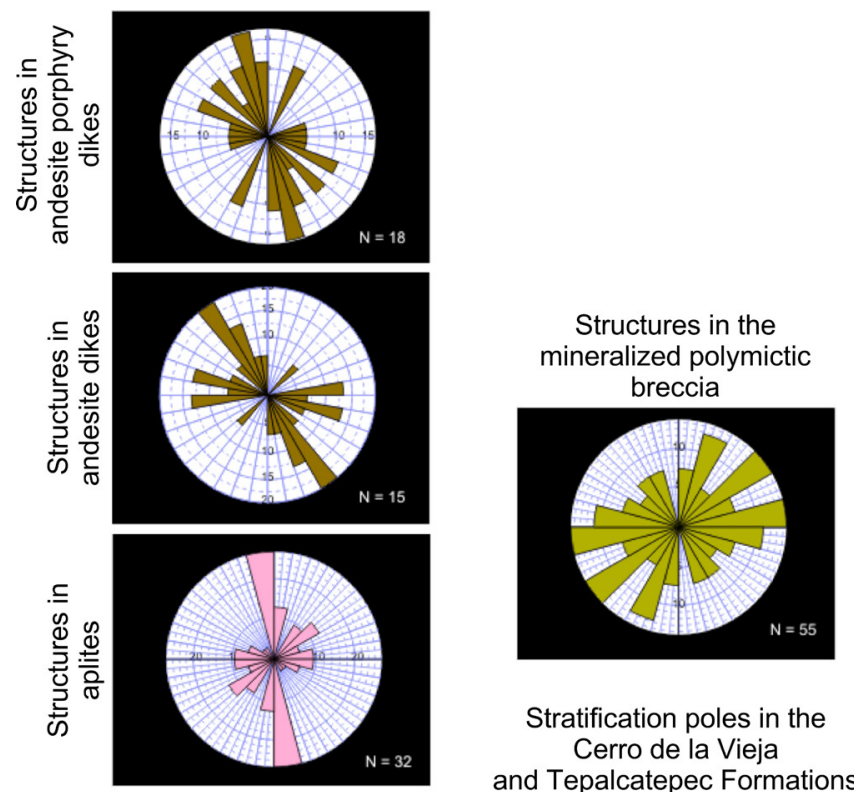

Stratification poles in the Cerro de la Vieja and Tepalcatepec Formations
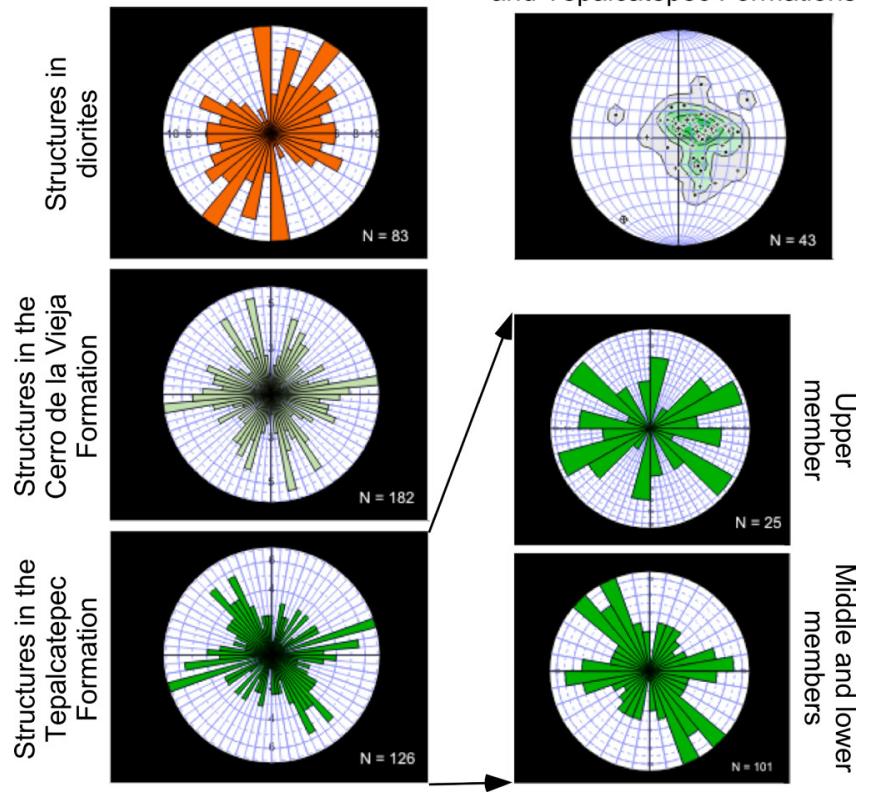

Figure 10 Distribution of structures in the analyzed lithological units in the Peña Colorada mine by means of equal area stereographic projections of stratification poles and strikes of faults or fractures. structures, either sinistral (La Chula and La Salada faults) or dextral (Autlán, Chinforinazo and Nido del Águila faults). Among these structures, the kilometer-sized Autlán strike-slip to normal fault is the most conspicuous trait of this domain and corresponds to a reactivated structure in the pre-Cretaceous basement. The WNW-ESE domain shows no less than two periods of movement. It is uncertain which type of movement was dominant during its initiation, but the deep reach of the Autlán fault and the apparent offset between rocks on either side of the fault suggest that it was initially a normal fault. The most recent activity of the Autlán fault corresponds to a transtensive movement that displaces the diorite stock (?) and aplite dikes laterally. Other faults with recent activity in this domain also displace the Cretaceous volcano-sedimentary sequence and the iron oxide bodies, and include ancillary discontinuous structures. N-S- and WNW-ESE-striking fractures host massive magnetite veins that seemingly "fed" the semi-stratabound massive body.

The $\mathrm{E}-\mathrm{W}$ structural domain includes both strikeslip (dominantly sinistral) and normal faults, and hosts late calcite veins and a massive magnetite vein, possibly associated with the late polymictic breccia, and monzonite dikes. Geometric and kinematic congruencies suggest that this domain was involved in reactivating the Autlán fault. The concentration of structures of this domain is high (Figure 9, inset), and includes evidence for at least one episode of reactivation.

The NW-SE structural domain consists of sinistral strike-slip faults that displaced monzonite dikes and controlled the emplacement of andesite dikes. Therefore, this domain is confined in time by the emplacement of the two sets of dikes (Figure 10). The high concentration of structures in this domain has to do with its late character in the structural evolution of the area. Although no clear reactivation can be deduced for structures of this domain, such possibility cannot be discarded as the contacts of andesite dikes are sheared.

The NE-SW structural domain is the most recent one in the area (Figure 9) and includes the 
Minatitlán fault and graben. First-order faults in this domain are essentially normal (with a domino geometry) with some strike-slip movement, and second-order sinistral strike-slip faults displaced monzonite dikes. The apparent offset associated with the Minatitlán fault cannot be determined in the absence of a reliable level of reference, but it is estimated to be more than $200 \mathrm{~m}$ by using the distribution of the Cerro de la Vieja Formation. Foliation with the same general strike as this domain was found in the disseminated orebody; therefore, this domain clearly postdates the formation of iron oxide bodies. As previously stated, the NE-SW domain is associated with recent structural and seismic activity.

\section{Mineral chemistry}

The composition of magnetite, apatite, and pyroxenes was determined by means of electron probe microanalysis (EPMA) in samples that are representative of all mineralization stages and mineral associations in the Peña Colorada deposit. The number of acceptable analyses for all minerals is approximately 900 . This study was carried out with the use of a Cameca CAMEBAX SX-50 equipment that was formerly available at the SCT of the Universitat de Barcelona and a JEOL JXA8900R equipment available at the Instituto de Geofísica of the Universidad Nacional Autónoma de México, with an acceleration voltage of $20 \mathrm{keV}$, a probe current of $2.0 \times 10^{-8} \mathrm{~A}$, a beam diameter of $1 \mu \mathrm{m}$, and acquisition times between 30 and 60 $\mathrm{s}(10 \mathrm{~s}$ for $\mathrm{Na}$ and $\mathrm{K})$.

Average results for EPMA are displayed in Table 1, results for acceptable individual analyses in Appendix 1 in Supplementary Material, magnetite compositions in Figure 11, apatite compositions in Figure 12, and pyroxene compositions in Figure 13. Selected back-scattered electron images that are representative for the various minerals and mineral associations selected for this study are shown in Figure 6. Oxygen fugacity $\left(\mathrm{O}_{2}\right)$ was calculated using Mn concentration of apatite and based on the linear equation proposed for silicic magmas by Miles et al. (2014). The values of log $\mathrm{fO}_{2}$ in the massive body and the upper and lower part of the polymictic breccia vary between -10.28 \pm 0.53 and $-10.26 \pm 0.53$ (Table 1), indicating that the apatites were crystallized in high oxidation conditions.

In general, little difference in composition for each analyzed mineral was detected among the selected locations for EPMA or the mineral associations to which they belong. This is true for the pyroxene compositions. Pyroxenes are diopside rich, indicating low temperatures of crystallization (less than about $300{ }^{\circ} \mathrm{C}$ ). All apatite-group mineral samples from the Peña Colorada deposit are fluorapatite (Table 1, Appendix 1 in Supplementary Material). The sole exceptions to such relative homogeneity are the higher contents in La and Ce of fluorapatite in the upper part of the polymictic breccia. Ce contents in fluorapatite, though, are significantly higher in this deposit than in other magmatic-hydrothermal iron oxide deposits and any other type of deposits (see Mao et al., 2016; Mukherjee et al., 2017). Among minor cations in magnetite, Ti shows the highest values (up to 10.355 wt.\%; Appendix 1 in Supplementary Material); interestingly, the $\mathrm{Ti}$ content in magnetite decreases with height in the late polymictic breccia, with average $\mathrm{TiO}_{2}$ contents of $1.362,0.770$, and $0.408 \mathrm{wt} . \%$ in the lower, middle, and upper part of the breccia, respectively. $\mathrm{Mg}$, an element that is commonly used as a petrogenetic indicator in magnetite, is between 35 and 1431 ppm.

The contents of minor metals in apatite (Figure 12) plot in the area of overlap of the low temperature hydrothermal system, the mafic system, and the system unrelated to intermediate-mafic rocks, as defined by Piccoli and Candela (2002), with outliers in the latter and the hydrothermal systems. However, almost all concentrations plot in the low-temperature hydrothermal system. The content of minor metals in magnetite (Figure 11) plots astride the fields of magmatic and hydrothermal magnetite and, rather inconclusively, is widely spread across the compositional fields of porphyry, 


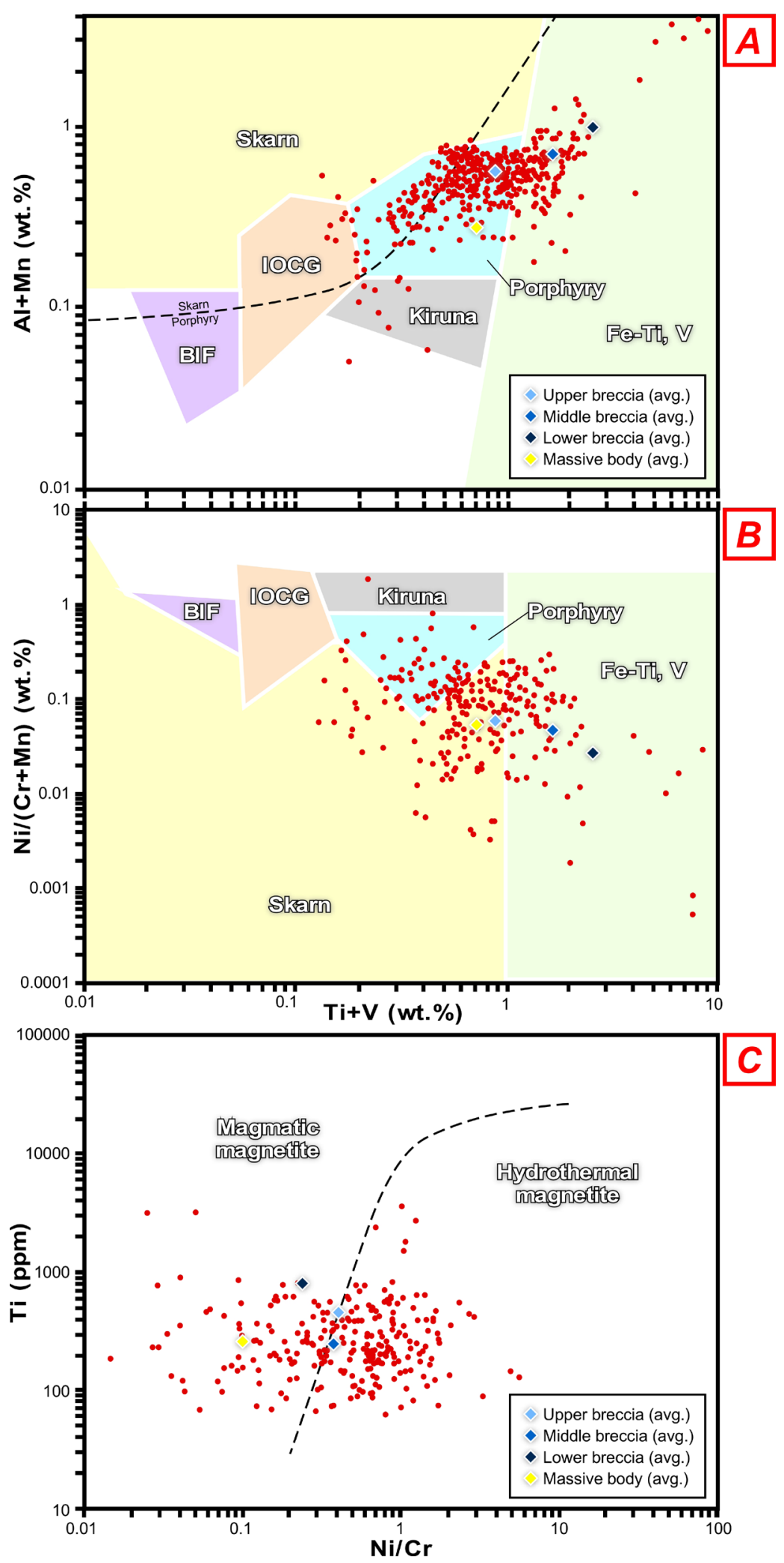

Figure 11 Discrimination diagrams for the possible origins of magnetite based upon its chemical composition in the Peña Colorada deposit. (A) Ti+V vs. Al+Mn (Nadoll et al., 2014). (B) Ti+V vs. Ni/(Cr+Mn) (Dupuis and Beaudoin, 2011). (C) Ni/Cr vs. Ti (Dare et al., 2012). Red dots correspond to individual EPMA analyses, whereas diamonds correspond to average values of the analyzed mineral associations. 
Table 1. Average compositions of pyroxene, apatite, and magnetite in different mineral associations of the Peña Colorada deposit, from EPMA analyses. Values of $\log f\left(\mathrm{O}_{2}\right)$ calculated by using Mn contents in apatite and the equation by Miles et al. (2014). See all analyses in Appendix 1 in Supplementary Material.

\begin{tabular}{|c|c|c|c|c|c|c|c|c|c|c|c|c|}
\hline PYROXENE & $\mathrm{SiO}_{2}$ & $\mathbf{K}_{2} \mathbf{O}$ & $\mathrm{Na}_{2} \mathrm{O}$ & $\mathrm{TiO}_{2}$ & $\mathrm{Al}_{2} \mathbf{O}_{3}$ & $\mathrm{Cr}_{2} \mathrm{O}_{3}$ & FeO & MgO & NiO & $\mathrm{CaO}$ & MnO & \\
\hline Massive body & 54.060 & 0.008 & 0.614 & 0.086 & 0.759 & 0.001 & 6.228 & 14.390 & 0.005 & 23.423 & 0.111 & \\
\hline Disseminated body & 53.614 & 0.008 & 0.778 & 0.034 & 0.350 & 0.007 & 8.706 & 12.853 & 0.006 & 22.885 & 0.159 & \\
\hline \multirow[t]{6}{*}{ Lower breccia } & 52.701 & 0.004 & 0.436 & 0.073 & 0.382 & 0.002 & 9.878 & 12.237 & 0.006 & 23.597 & 0.801 & \\
\hline & apfu & & & & & & & & & & & total \\
\hline & $\mathrm{Si}$ & $\mathbf{K}$ & $\mathrm{Na}$ & $\mathrm{Ti}$ & Al & $\mathrm{Cr}$ & $\mathrm{Fe}$ & Mg & $\mathbf{N i}$ & $\mathrm{Ca}$ & Mn & cations \\
\hline & 1.998 & 0.000 & 0.022 & 0.002 & 0.000 & 0.000 & 0.193 & 0.792 & 0.000 & 0.928 & 0.003 & 3.940 \\
\hline & 2.009 & 0.000 & 0.028 & 0.001 & 0.000 & 0.000 & 0.273 & 0.717 & 0.000 & 0.919 & 0.005 & 3.954 \\
\hline & 1.983 & 0.000 & 0.016 & 0.002 & 0.000 & 0.000 & 0.311 & 0.687 & 0.000 & 0.952 & 0.026 & 3.977 \\
\hline
\end{tabular}

\begin{tabular}{|r|c|c|c|c|c|c|c|c|c|c|c|c|c|}
\hline APATITE & $\mathbf{P}_{\mathbf{2}} \mathbf{O}_{\mathbf{5}}$ & $\mathbf{L a}_{\mathbf{2}} \mathbf{O}_{\mathbf{3}}$ & $\mathrm{Ce}_{\mathbf{2}} \mathbf{O}_{\mathbf{3}}$ & $\mathbf{M g O}$ & $\mathbf{C a O}$ & $\mathbf{M n O}$ & $\mathbf{F e O}$ & $\mathbf{S r O}$ & $\mathbf{N a}_{\mathbf{2}} \mathbf{O}$ & $\mathbf{K}_{\mathbf{2}} \mathbf{O}$ & $\mathbf{H}_{2} \mathbf{O}$ & $\mathbf{F}$ & $\mathbf{C l}$ \\
\hline Upper breccia & 40.645 & 0.140 & 0.280 & 0.006 & 55.292 & 0.023 & 0.211 & 0.001 & 0.083 & 0.003 & 0.000 & 3.663 & 0.804 \\
\hline Lower breccia & 40.294 & 0.078 & 0.147 & 0.017 & 55.967 & 0.024 & 0.066 & 0.001 & 0.233 & 0.003 & 0.000 & 3.701 & 0.971 \\
Massive body & 40.967 & 0.062 & 0.138 & 0.011 & 55.726 & 0.025 & 0.084 & 0.001 & 0.133 & 0.036 & 0.000 & 3.739 & 0.411 \\
\hline
\end{tabular}

\begin{tabular}{|c|c|c|c|c|c|c|c|c|c|c|c|c|c|c|}
\hline apfu & & & & & & & & & & & & & total & \\
\hline $\mathbf{P}$ & La & $\mathrm{Ce}$ & $\mathbf{M g}$ & $\mathrm{Ca}$ & Mn & $\mathrm{Fe}$ & $\mathrm{Sr}$ & $\mathrm{Na}$ & K & $\mathrm{H}_{2} \mathrm{O}$ & F & $\mathrm{Cl}$ & cations & $\log f\left(\mathrm{O}_{2}\right)$ \\
\hline 2.830 & 0.004 & 0.009 & 0.001 & 4.883 & 0.002 & 0.013 & 0.000 & 0.013 & 0.000 & 0.000 & 0.952 & 0.114 & 8.821 & $-10.26 \pm 0.53$ \\
\hline 2.809 & 0.002 & 0.004 & 0.002 & 4.939 & 0.002 & 0.005 & 0.000 & 0.037 & 0.000 & 0.000 & 0.964 & 0.136 & 8.901 & $-10.27 \pm 0.53$ \\
\hline 2.836 & 0.002 & 0.004 & 0.001 & 4.881 & 0.002 & 0.006 & 0.000 & 0.021 & 0.004 & 0.000 & 0.967 & 0.057 & 8.780 & $-10.28 \pm 0.53$ \\
\hline
\end{tabular}

\begin{tabular}{|c|c|c|c|c|c|c|c|c|c|c|}
\hline MAGNETITE & $\mathbf{T i O}_{\mathbf{2}}$ & $\mathbf{A l}_{\mathbf{2}} \mathbf{O}_{\mathbf{3}}$ & $\mathbf{V}_{\mathbf{2}} \mathbf{O}_{\mathbf{3}}$ & $\mathbf{C r}_{\mathbf{2}} \mathbf{O}_{\mathbf{3}}$ & $\mathbf{F e O}$ & $\mathbf{F e}_{\mathbf{2}} \mathbf{O}_{\mathbf{3}}$ & $\mathbf{M g O}$ & $\mathbf{M n O}$ & $\mathbf{N i O}$ & $\mathbf{Z n O}$ \\
\hline Upper breccia & 0.408 & 0.405 & 0.154 & 0.018 & 31.410 & 66.960 & 0.323 & 0.182 & 0.013 & 0.032 \\
\hline Middle breccia & 0.770 & 0.469 & 0.148 & 0.019 & 30.515 & 66.254 & 0.432 & 0.244 & 0.013 & 0.030 \\
Lower breccia & 1.362 & 0.541 & 0.214 & 0.021 & 30.989 & 65.298 & 0.467 & 0.391 & 0.011 & 0.054 \\
Massive body & 0.425 & 0.058 & 0.649 & 0.302 & 31.354 & 67.827 & 0.232 & 0.130 & 0.014 & 0.009 \\
\hline
\end{tabular}

\begin{tabular}{|c|c|c|c|c|c|c|c|c|c|}
\hline pfu & & & & & & & & & \\
\hline $\mathbf{T i}$ & Al & V & $\mathrm{Cr}$ & $\mathrm{Fe}^{2+}$ & $\mathrm{Fe}^{3+}$ & $\mathbf{M g}$ & Mn & $\mathrm{Ni}$ & $\mathrm{Zn}$ \\
\hline 0.012 & 0.019 & 0.005 & 0.001 & 0.922 & 2.014 & 0.019 & 0.006 & 0.000 & 0.001 \\
\hline 0.023 & 0.022 & 0.005 & 0.001 & 0.919 & 1.995 & 0.026 & 0.008 & 0.000 & 0.001 \\
\hline 0.041 & 0.025 & 0.007 & 0.001 & 0.928 & 1.956 & 0.028 & 0.013 & 0.000 & 0.002 \\
\hline 0.017 & 0.002 & 0.019 & 0.014 & 0.926 & 2.003 & 0.425 & 0.004 & 0.000 & 0.000 \\
\hline
\end{tabular}

Key: apfu = atoms per formula unit.

skarn, Fe-Ti-V, Kiruna-type, and IOCG deposits (as of Dupuis and Beaudoin, 2011; Dare et al., 2012; Nadoll et al., 2014).

\section{Geochronology and geochemistry}

\subsection{APATITE FISSION TRAGK DATING AND REE GEOCHEMISTRY}

Heavy minerals were concentrated using conventional techniques and instruments such as crushing, sieving, Wilfley table, Frantz separator, and heavy liquids. Approximately 100 apatites, picked from each rock sample under a binocular microscope, were mounted with epoxy resin in a $2.5 \mathrm{~cm}$ diameter plastic ring, and then polished. Polished apatites were etched in $5.5 \mathrm{M} \mathrm{HNO}_{3}$ at $21{ }^{\circ} \mathrm{C}$ for
20 s (e.g., Donelick et al., 2005) to reveal ${ }^{238} \mathrm{U}$ spontaneous fission tracks. Spontaneous fission track counting and confined (horizontal) track length measurements were performed using an Olympus BX51 microscope with a $100 \times$ dry objective at a total magnification of $1500 \times$. Sample preparation, chemical etching, and optical studies were carried out at the Instituto de Geología (UNAM). The trace element (Mn, Sr, Y, U, and Th) and REE (from $\mathrm{La}$ to $\mathrm{Lu}$, except $\mathrm{Pm}$ and $\mathrm{Tm}$ ) measurements in apatites were performed at the Laboratorio de Estudios Isotópicos of the Centro de Geociencias (UNAM), using a Resonetics M050 $193 \mathrm{~nm}$ ArF excimer laser ablation system coupled to a Thermo iCAP-Qc quadrupole ICP-MS. Details of the methodology used in this study are presented in Abdullin et al. (2014). Apatite fission track (AFT) ages and absolute errors were calcu- 


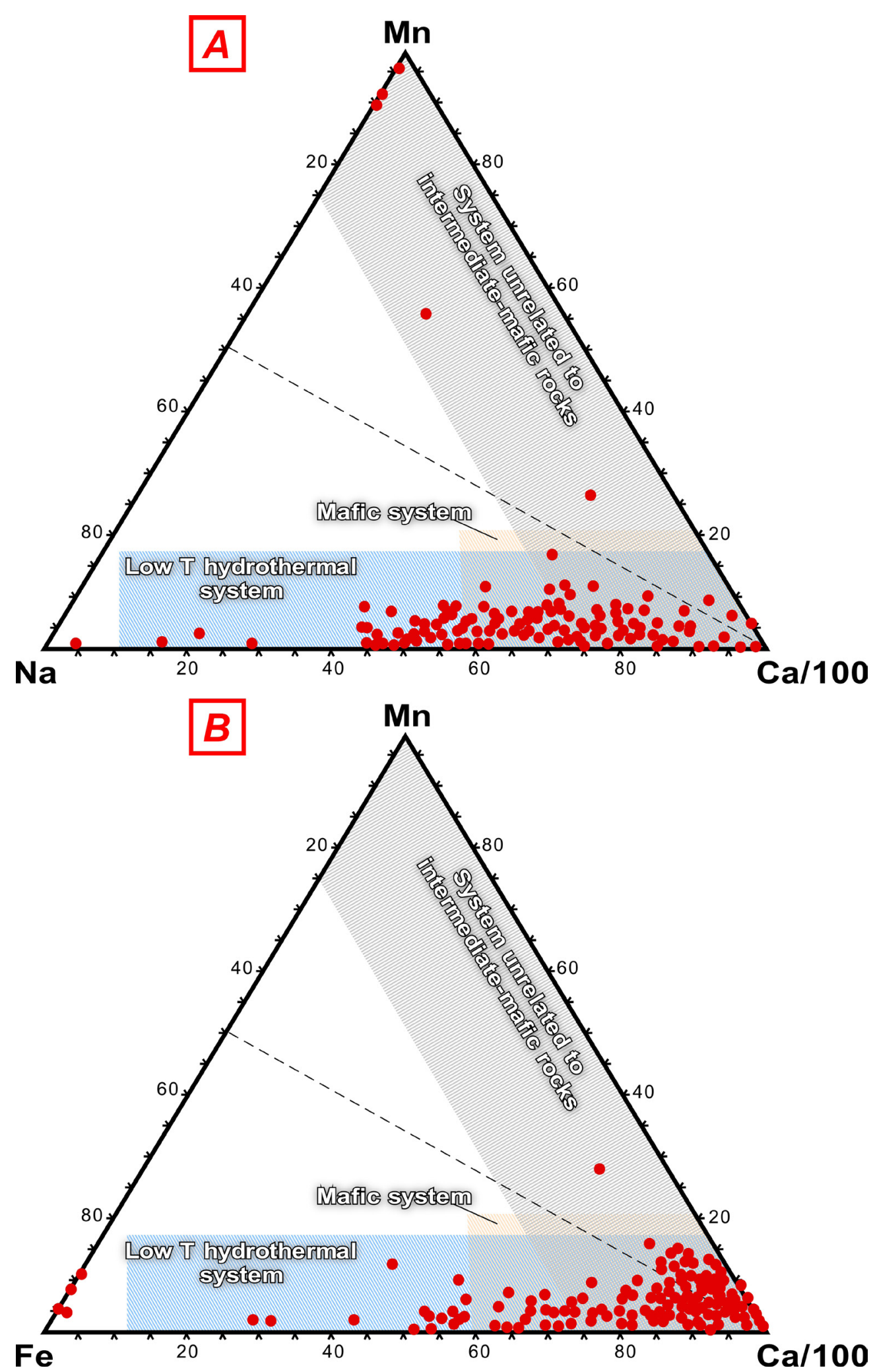

Figure 12 Discrimination diagrams for the possible origins of apatite in magmatic systems based upon the chemical composition of this mineral (as of Piccoli and Candela, 2002) and plotted compositions for apatite (red dots) in the massive and disseminated bodies, and as fragments of pegmatoid magnetite + apatite + pyroxene rock in the lower part of the breccia in the Peña Colorada deposit. (A) $\mathrm{Na}-\mathrm{Ca}-\mathrm{Mn}$. (B) Fe-Ca-Mn. Scales are in wt.\%.. 
lated following Hasebe et al. (2004) and Abdullin et al. (2014), respectively. Additionally, REE in whole apatite crystals from the same mineral associations that were analyzed by means of LA-ICP-MS were also analyzed by means of an Agilent 7500 ce quadrupole ICP-MS available at the Instituto de Geología (UNAM). An apatite sample from the Cerro de Mercado deposit in Durango was included in the analysis for comparison.

AFT dating results are listed in Table 2 and Appendix 2 in Supplementary Material, and displayed in Figure 14. Both samples M1 and M2 passed the chi-squared probability test (Table 2 ), which indicates that all the analyzed apatites belong to a single population of ages (Galbraith, 1981). Sample M1 yielded the pooled age of 53 $\pm 2(1 \sigma) \mathrm{Ma}$ (Arrayanes magnetite plus apatite veins) (Table 2, Figure 14). Sample M2 yielded the pooled age of $59 \pm 2(1 \sigma) \mathrm{Ma}$ (Peña Colorada magnetite plus apatite plus pyroxene veins) (Table 2, Figure 14). Apatites from the studied rocks have the Dpar values (Donelick et al., 2005) from $1.7 \pm$ $0.1(1 \sigma) \mu \mathrm{m}$ to $1.9 \pm 0.1(1 \sigma) \mu \mathrm{m}$ (Table 2). Thus, the effective closure temperature for these apatites can be taken as 110 to $120^{\circ} \mathrm{C}$. Apatites from two samples give approximately similar mean confined track lengths of $14.5 \pm 0.7(1 \sigma) \mu \mathrm{m}$ and $14.3 \pm 0.6$ $(1 \sigma) \mu \mathrm{m}$, which closely correspond to volcanic-type cooling (Gleadow et al., 1986). This suggests that the samples were cooled rapidly through the partial annealing zone of approximately $60^{\circ}$ to 120 ${ }^{\circ} \mathrm{C}$.

Average REE concentrations in fluorapatite are displayed in Table 3 and Figure 14, and individual analyses in Appendix 3 in Supplementary Material. Oxygen fugacity $\left(\mathrm{O}_{2}\right)$ was calculated using Mn concentration of apatite and based on the linear equation proposed for silicic magmas by Miles et al. (2014). The values of $\log f \mathrm{O}_{2}$ vary between $-10.9 \pm 0.6$ and $-10.1 \pm 0.5$ (Table 3), indicating that the apatites crystallized in high oxidation conditions, in close agreement with EPMA results. SLREE (La, Ce, Pr, Nd, Sm, and Eu) values in the analyzed samples range between 2407 and 10761 ppm and SHREE (Gd, Tb, Dy, Ho, Er, Tm, Yb, and $\mathrm{Lu}$ ) values range between 303 an 975 ppm. Both SLREE and SHREE values are found within the compositional range determined by Mao et al. (2016) as characteristic for IOCG and Kiruna-type deposits. Similar to EPMA analyses (see above), the Ge contents in fluorapatite obtained by LA-ICP-MS are significantly higher in this deposit than in other magmatic-hydrothermal iron oxide deposits (and several other types of deposits ): Ce/ Ce* values (Lodders, 2010, in Mao et al., 2016) in the Peña Colorada deposit and the Arrayanes pros-

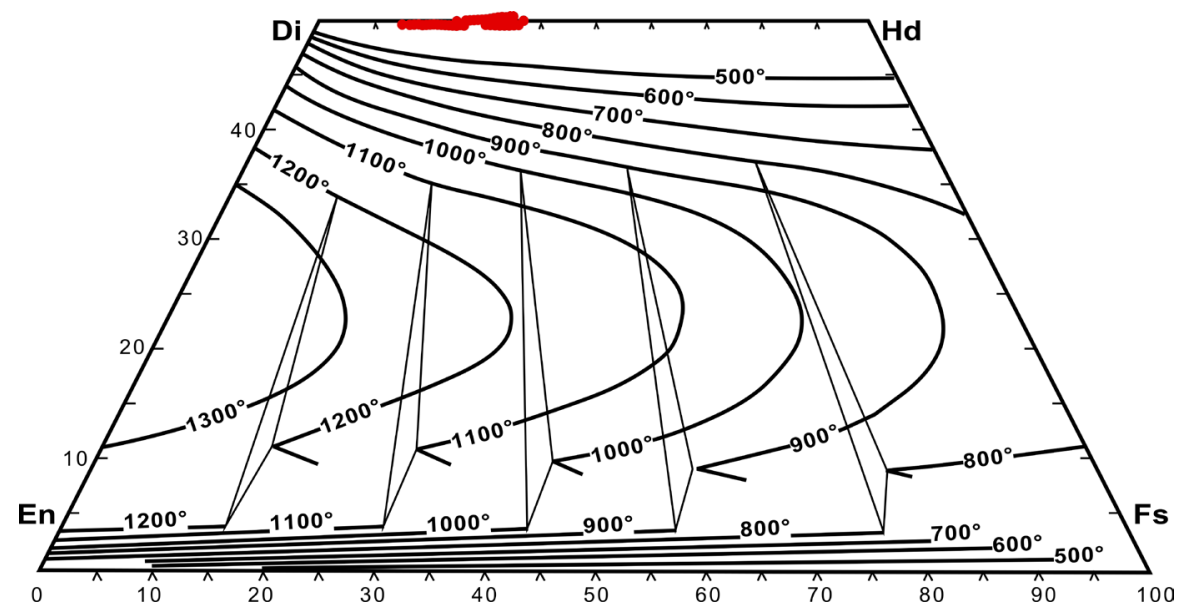

Figure 13 Pyroxene thermometry diagram in ${ }^{\circ} \mathrm{C}$ by Lindsley (1983) with the plotted compositions of pyroxenes in the massive and disseminated bodies, and as fragments of pegmatoid magnetite + apatite + pyroxene rock in the lower part of the breccia in the Peña Colorada deposit (red dots). All analyses in this study correspond to low-temperature diopside (possibly $\leq 300{ }^{\circ} \mathrm{C}$ ). $\mathrm{Key}$ : $\mathrm{Di}=$ diopside; En = enstatite; Fs = ferrosilite; $\mathrm{Hd}$ = hedenbergite. 
Table 2. Average results of the LA-ICP-MS-based apatite fission track dating for samples from the Peña Colorada and Arrayanes deposits.

\begin{tabular}{|c|c|c|c|c|c|c|c|c|c|}
\hline Sample & $\mathbf{N}_{\mathrm{GR}}$ & $\mathrm{N}_{\mathrm{s}}$ tot & $\begin{array}{l}p_{S}\left(\times 10^{5} \mathrm{~cm}^{-2}\right) \\
\mathrm{min} / \mathrm{mean} / \mathrm{max}\end{array}$ & $\begin{array}{c}{ }^{238} \mathrm{U}(\mathrm{ppm}) \\
\mathrm{min} / \mathrm{mean} / \mathrm{max}\end{array}$ & $\begin{array}{c}\text { AFT age } \pm 1 \sigma \\
\text { (Ma) } \\
\text { min } / \text { mean } / \max \end{array}$ & $P\left(\chi^{2}\right)$ & $\mathbf{N}_{\mathrm{CT}}$ & MTL \pm SD $(\mu \mathrm{m})$ & Dpar \pm SD $(\mu \mathrm{m})$ \\
\hline M1, Arrayanes & 10 & 130 & $\begin{array}{c}0.8333 / \mathbf{1 . 2 0 0 0} / \\
1.8333\end{array}$ & $3.2 / 4.5 / 6.8$ & $\begin{array}{c}50.3 \pm 6.0 / \mathbf{5 3} \pm \\
\mathbf{2} / 54.9 \pm 6.4\end{array}$ & $100 \%$ & 4 & $14.5 \pm 0.7$ & $1.7 \pm 0.1$ \\
\hline $\begin{array}{l}\text { M2, Peña } \\
\text { Colorada }\end{array}$ & 9 & 135 & $\begin{array}{c}0.9000 / \mathbf{2 . 8 1 5 0} / \\
5.8333\end{array}$ & $2.9 / \mathbf{9 . 3} / 19.1$ & $\begin{array}{c}53.3 \pm 7.5 / 59 \pm \\
\mathbf{2} / 65.1 \pm 9.4\end{array}$ & $100 \%$ & 7 & $14.3 \pm 0.6$ & $1.9 \pm 0.1$ \\
\hline
\end{tabular}

Key: $\mathrm{N}_{\mathrm{GR}}=$ number of dated apatite crystals; $\mathrm{NS}$ tot = sum of the ${ }^{238} \mathrm{U}$ spontaneous fission tracks registered for all apatites; $p S=$ spontaneous track density; ${ }^{238} \mathrm{U}=$ uranium-238 concentration in ppm measured by LA-ICP-MS; AFT age = apatite fission track age in Ma with its absolute $\pm 1 \sigma$ error; $P\left(x^{2}\right)=$ chi-squared probability; $\mathrm{N}_{\mathrm{CT}}=$ number of measured confined (horizontal) tracks; $M$ TL $=$ mean track length in $\mu \mathrm{m}$ with its standard deviation; Dpar = mean etch-pit length (Donelick et al., 2005); SD = standard deviation (1 $\sigma$ ).

pect are between 4 and 5. Conversely, Eu contents in fluorapatite in this study are lower than in other magmatic-hydrothermal deposits of either type: $\mathrm{Eu} / \mathrm{Eu}^{*}$ values (Lodders, 2010, in Mao et al., 2016) in the Peña Colorada deposit and the Arrayanes prospect are between 0.03 and 0.09 . Mn versus $\mathrm{Sr}$ and $\mathrm{Y}$ versus Sr contents in fluorapatites agree very well with those of other iron ores (compare data in Appendix 3 in Supplementary Material with figures $4 \mathrm{a}-\mathrm{b}$ in Belousova et al., 2002), which is not the case for $\mathrm{Y}$ versus $\mathrm{Eu} / \mathrm{Eu}^{*}$ values due to the low Eu content in the fluorapatites.

\section{2. ${ }^{40} \mathrm{Ar} /{ }^{39} \mathrm{Ar}$ DATING}

Ten K-feldspar separates were obtained for ${ }^{40} \mathrm{Ar} /{ }^{39} \mathrm{Ar}$ dating from disseminated, massive, and breccia bodies; from part of the barren potassic alteration; and from an andesite dike at Peña Colorada. Each of the ten samples were from different single-mineral associations. K-feldspar separates from the selected samples were dated with ${ }^{40} \mathrm{Ar} /{ }^{39} \mathrm{Ar}$ geochronology (Figure 8, Appendices 4 and 5 in Supplementary Material). The mineral separates ranged in size between 180 and $250 \mu \mathrm{m}$ and were produced using heavy liquids and hand picking techniques to a purity of $>99 \%$. Samples were washed in acetone, alcohol, and deionized water in an ultrasonic cleaner to remove dust and then re-sieved by hand using a $180 \mu \mathrm{m}$ sieve. Aliquots of the samples $(8.8 \mathrm{mg})$ were packaged in copper capsules and sealed under vacuum in quartz tubes. The sample was then irradiated for 20 hours in the central thimble facility at the
TRIGA reactor (GSTR) at the U.S. Geological Survey in Denver, Colorado. The monitor mineral used in the package was Fish Canyon Tuff sanidine (FCT-3) with an age of 27.79 Ma (Kunk et al., 1985; Cebula et al., 1986) relative to MMhb-1 with an age of 519.4 $\pm 2.5 \mathrm{Ma}$ (Alexander et al., 1978; Dalrymple et al., 1981). The type of container and the geometry of sample and standards is similar to that described by Snee et al. (1988). The sample was analyzed at the U.S. Geological Survey Thermochronology lab in Denver, Colorado, using the ${ }^{40} \mathrm{Ar} /{ }^{39} \mathrm{Ar}$ step-heating method of dating with a VG Isotopes 1200B mass spectrometer fitted with an electron multiplier. For additional information on the analytical procedure see Kunk et al. (2001). The argon isotopic data were reduced using the computer program Ar/Ar* (Haugerud and Kunk, 1988). We used the decay constants recommended by Steiger and Jäger (1977).

Table 2 shows ${ }^{40} \mathrm{Ar} /{ }^{39} \mathrm{Ar}$ step-heating data and includes the identification of individual step, plateau, average, and total gas ages. An individual step age represents the apparent age obtained for a single temperature step analysis. A plateau age is identified when three or more contiguous steps in the age spectrum agree in age, within the limits of analytical precision, and contain more than 50\% of the ${ }^{39} \mathrm{Ar}_{\mathrm{K}}$ released from the sample. The average age is calculated from contiguous steps forming no plateau but containing more than $50 \%$ of the gas with the intention of obtaining the best age approximation for the sample. The total gas age represents the age calculated from the addition of all of the measured argon peaks for all steps in a 


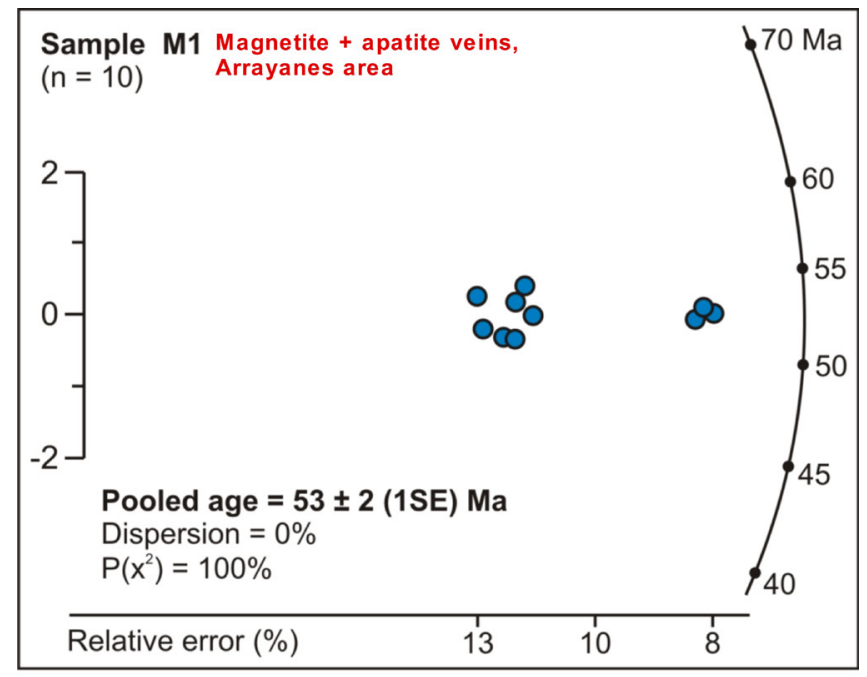

Sample M2 Magnetite + apatite + pyroxene "xenoliths" \70 Ma $(n=9) \quad$ in polymictic breccia, Peña Colorada

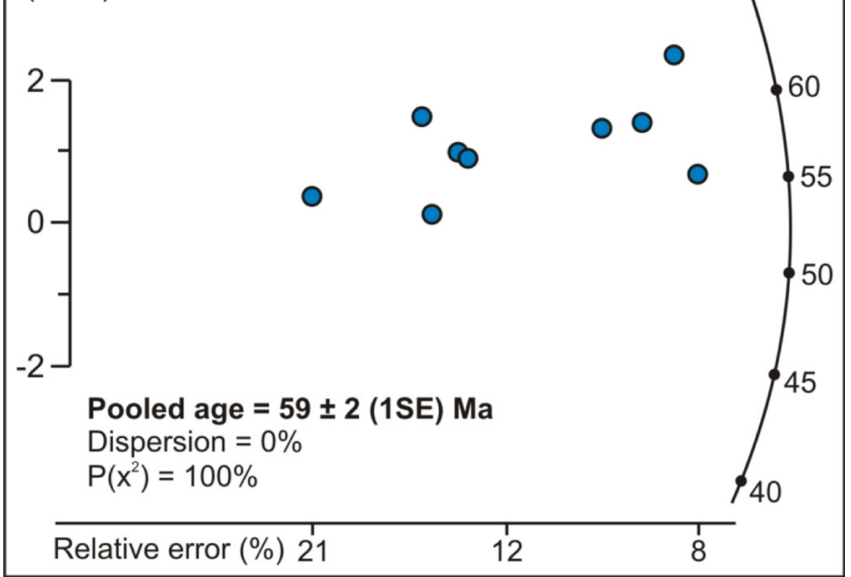

Figure 14 Radial plots of fission tracks in apatite for samples from magnetite + apatite + pyroxene "xenoliths" in the polymictic breccia at Peña Colorada and the magnetite + apatite veins in the Arrayanes area. Key: $\mathbf{n}=$ number of dated apatites.

single sample. The total gas age is roughly equivalent to conventional K-Ar ages. No analytical precision is calculated for the total gas age.

We have also calculated isochron ages using an inverse-isotope correlation diagram that plots ${ }^{39} \mathrm{Ar} /{ }^{40} \mathrm{Ar}$ against ${ }^{36} \mathrm{Ar} /{ }^{40} \mathrm{Ar}$ (Figure 16, Appendices 4 and 5 in Supplementary Material). When reporting the isochron age we include the isochron age of the sample (calculated from the inverse of the x-axis intercept), the calculated initial ${ }^{40} \mathrm{Ar} /{ }^{36} \mathrm{Ar}$ ratio of the sample (the inverse of the y-axis intercept), the MSWD a goodness of fit indicator of the data (Mean Standard of Weighted Deviates), the number of steps used in the age regression, and the percentage of ${ }^{39} \mathrm{Ar}_{\mathrm{K}}$ that they represent. Most runs yielded good isochron ages. ${ }^{40} \mathrm{Ar} /{ }^{39} \mathrm{Ar}$ dating in K-feldspar from different mineral associations at the Peña Colorada deposit yielded the following ages:

1. $63.26 \pm 0.85$ and $63.26 \pm 0.52 \mathrm{Ma}$ for a magnetite-rich piece of deep potassic alteration upthrown by faulting into the disseminations below the massive body,

2. $59.39 \pm 0.21 \mathrm{Ma}$ for an andesite dike with trace magnetite,

3. $\quad 55.72 \pm 0.75,55.53 \pm 0.45,54.90 \pm 1.1,54.84$ $\pm 2.83 \mathrm{Ma}$ for garnetites in the massive body that were completely replaced by potassic alteration, and pervasive potassic alteration within the disseminations below the massive body, and

4. $50.70 \pm 0.40,48.30 \pm 0.30$ and $48.18 \pm 0.16$ Ma for the polymictic breccia and the adjacent potassic alteration that was developed on Gretaceous volcano-sedimentary rocks (barren, unlike potassic alteration assemblages associated with the disseminated body).

All the available ages for events of mineralization and associated intrusive rocks in the study area are summarized in Figure 17 and Table 4.

\section{Discussion}

\subsection{IOA MINERALIZATION EVENTS IN THE PEÑA COLORADA AND ARRAYANES DEPOSITS}

The sequence of mineralization events in the Peña Colorada iron oxide-apatite (IOA) deposit is the result of several intrusion and hydrothermal mine ralization events: (1) intrusion of the Peña Colorada diorite, formation of garnetites as skarns or skarnoids, and formation of the syenite-like disseminated body; (2) intrusion of monzogranite and andesite dikes and of the neighboring El Mixcuate diorite, and formation of the main disseminated and massive iron oxide bodies (both 
Table 3. Average concentrations (in ppm) of trace elements measured in apatites from the Peña Colorada and Arrayanes deposits using LA-ICP-MS (samples M1 and M2) and ICP-MS.

\begin{tabular}{|c|c|c|c|c|c|c|c|c|c|c|c|c|c|c|c|c|c|c|c|c|}
\hline Sample & $\mathbf{N}_{\mathrm{GR}}$ & Mn & $\mathrm{Sr}$ & $\mathbf{Y}$ & $\mathrm{La}$ & $\mathrm{Ce}$ & $\operatorname{Pr}$ & Nd & $\mathrm{Sm}$ & Eu & Gd & Tb & Dy & Ho & Er & $\mathbf{T m}$ & $\mathbf{Y b}$ & Lu & Th & U \\
\hline M1* & 17 & 528 & 423 & 942 & 883 & 2254 & 297 & 1323 & 281 & 12.3 & 265 & 34 & 192 & 34.7 & 84.4 & & 51.2 & 6.4 & 12.4 & 4.7 \\
\hline $\mathrm{M} 2 * *$ & 14 & 143 & 430 & 780 & 866 & 1730 & 201 & 852 & 173 & 12.3 & 172 & 22 & 131 & 25.9 & 68.6 & & 44.9 & 5 & 50.8 & 7.9 \\
\hline $\mathrm{PC} 1 * *$ & 1 & & 382 & 499 & 594 & 1039 & 129 & 524 & 108 & 13 & 107 & 16 & 79 & 15 & 42 & 6 & 34 & 4 & 31 & \\
\hline $\mathrm{PC} 2 * *$ & 1 & & 396 & 500 & 602 & 1061 & 130 & 524 & 104 & 10 & 108 & 15 & 80 & 15 & 43 & 6 & 34 & 4 & 34 & \\
\hline $\mathrm{AR}^{*}$ & 1 & & 610 & 1410 & 2480 & 4640 & 652 & 2502 & 433 & 54 & 388 & 51 & 247 & 46 & 124 & 16 & 91 & 12 & 306 & \\
\hline $\mathrm{CM}_{\dagger}^{+}$ & 1 & & 497 & 839 & 3956 & 2791 & 434 & 1408 & 206 & 22 & 214 & 27 & 135 & 26 & 74 & 10 & 54 & 6 & 250 & \\
\hline Sample & ¿LREE & IHREE & IREE & $\log f \mathrm{O}_{2}$ & & & & & & & & & & & & & & & & \\
\hline M1* & 5038 & 457 & 5717 & $-10.9 \pm 0.6$ & & & & & & & & & & & & & & & & \\
\hline $\mathrm{M} 2^{* *}$ & 3822 & 303 & 4304 & $-10.1 \pm 0.5$ & & & & & & & & & & & & & & & & \\
\hline $\mathrm{PC} 1 * *$ & 2407 & 303 & 2710 & & & & & & & & & & & & & & & & & \\
\hline $\mathrm{PC} 2^{* *}$ & 2431 & 305 & 2736 & & & & & & & & & & & & & & & & & \\
\hline $\mathrm{AR}^{*}$ & 10761 & 975 & 11736 & & & & & & & & & & & & & & & & & \\
\hline $\mathrm{CM}^{\dagger}$ & 8817 & 546 & 9363 & & & & & & & & & & & & & & & & & \\
\hline
\end{tabular}

Key: $\mathrm{N}_{\mathrm{GR}}=$ number of analyzed apatite grains; $\mathrm{fO}_{2}=$ oxygen fugacity that was calculated on the basis of $\mathrm{Mn}$ content in apatite (Miles et al., 2014). "Arrayanes, **Peña Colorada, †Cerro de Mercado, Durango (for comparison).

semi-stratabound bodies and veins); and (3) intrusion of the neighboring magnetite-rich Llanitos gabbro and the associated diorite and microgranodiorite, and formation of the polymictic breccia. All the IOA ore bodies in the neighboring Arrayanes prospect appear to be associated with the sole intrusion event that comprises the Llanitos gabbro and its associated rocks. Such intrusive rocks have complex relations among them that can be associated with mixing or mingling processes. These intrusive rocks carried magmatic magnetite, which is visibly widespread as disseminations in the entire Arrayanes prospect, though significantly concentrated along mingling zones between gabbros and diorites. The occurrence of magnetite as a magmatic mineral within similar rocks was already noticed by González-Reyna (1956) in the diorite hypabyssal body in the southern part of the Peña Colorada area, now mostly concealed by mining activities in the area.

In the light of this study, we conclude that the formation of the main mineralized bodies in the Peña Colorada deposit (the massive and disseminated semi-stratabound ore bodies) is directly controlled by structural and stratigraphic features (Figure 18). Hydrothermal fluids would have found good channelways through volcanic or volcano-sedi- mentary rocks, whereas carbonate rocks would have played the role of impervious barriers that further promoted mineralization elsewhere. Such stratigraphic configuration established a sort of "horizontal sandwich" of volcano-sedimentary rocks between carbonate rocks. Such mechanism would have been enhanced by Laramide low-angle faults through the entire Cretaceous volcano-sedimentary sequence, which are the structures that truly host the massive semi-stratabound mineralization (Figure 18). Further, the lateral extension of volcano-sedimentary rocks is limited to the east and west of the mineralized area by $\mathrm{N}-\mathrm{S}$ strike-slip faults (due to structural domain 1 in this study), thus establishing a sort of "vertical sandwich" of volcano-sedimentary rocks between carbonate rocks in the central blocks and more carbonate rocks on either side of the central blocks (Figure 18). Such strike-slip faults are sinistral on the eastern side of the central blocks and dextral on the western side (Figure 5) and have been reactivated thereafter. The formation of the massive and disseminated bodies is associated with structural domain 2, which strikes WNW-ESE, as suggested by $\mathrm{N}-\mathrm{S}$ and $\mathrm{WNW}-\mathrm{ESE}$ massive magnetite veins that are interpreted here as likely feeder structures for hydrothermal fluids into the main mineralized 


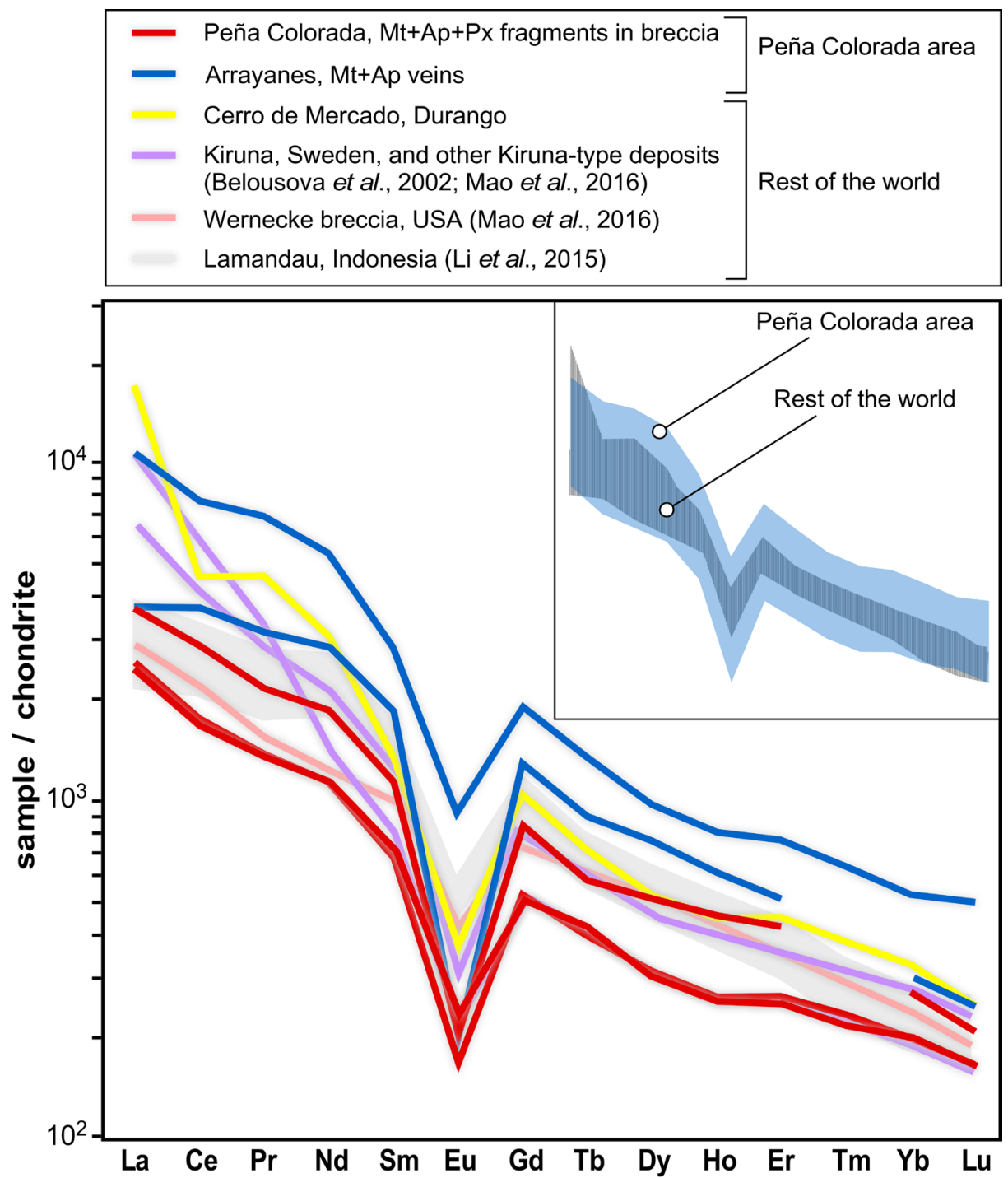

Figure 15 REE patterns for the apatite samples analyzed in this study (Peña Colorada, Arrayanes and Cerro de Mercado) normalized to chondrite values (McDonough and Sun, 1995), compared to those in other selected IOCG "clan" deposits.

zone.

IOA ore bodies are similar in the Peña Colorada and Arrayanes deposits, as both contain subhorizontal massive and disseminated magnetite bodies, massive magnetite veins, "pegmatoid" magnetite + fluorapatite \pm diopside veins, and breccias. "Pegmatoid" magnetite + fluorapatite \pm diopside associations are common in IOCG "clan" deposits and are associated with relatively high temperatures (e.g., El Laco in Chile; Naslund et al., 2002), although the analyzed diopsides in Peña Colorada would not yield temperatures greater than aproxi- mately $300^{\circ} \mathrm{C}$ (Figure 13). As discussed in sections 6.3 and 6.4, all the events of mineralization in the Arrayanes prospect may correspond genetically and temporally to the main event of mineralization in the Peña Colorada deposit, based upon structural, mineralogical, and geochronological criteria.

Despite the similarities in styles of mineralization between the Peña Colorada and Arrayanes IOA deposits, their differences in the pervasiveness and abundance of potassic, sodic, and propylitic alteration assemblages suggest drastic differences 
in their depth of formation. All mineralization events in the Peña Colorada deposit (and the La Fundición prospect) are associated with potassic (see Figure 6) or with propylitic alteration, which is particularly conspicuous in the upper part of the deposit. In contrast, sodic alteration assemblages are starkly subordinate in this deposit. Conversely, sodic alteration is widespread in the
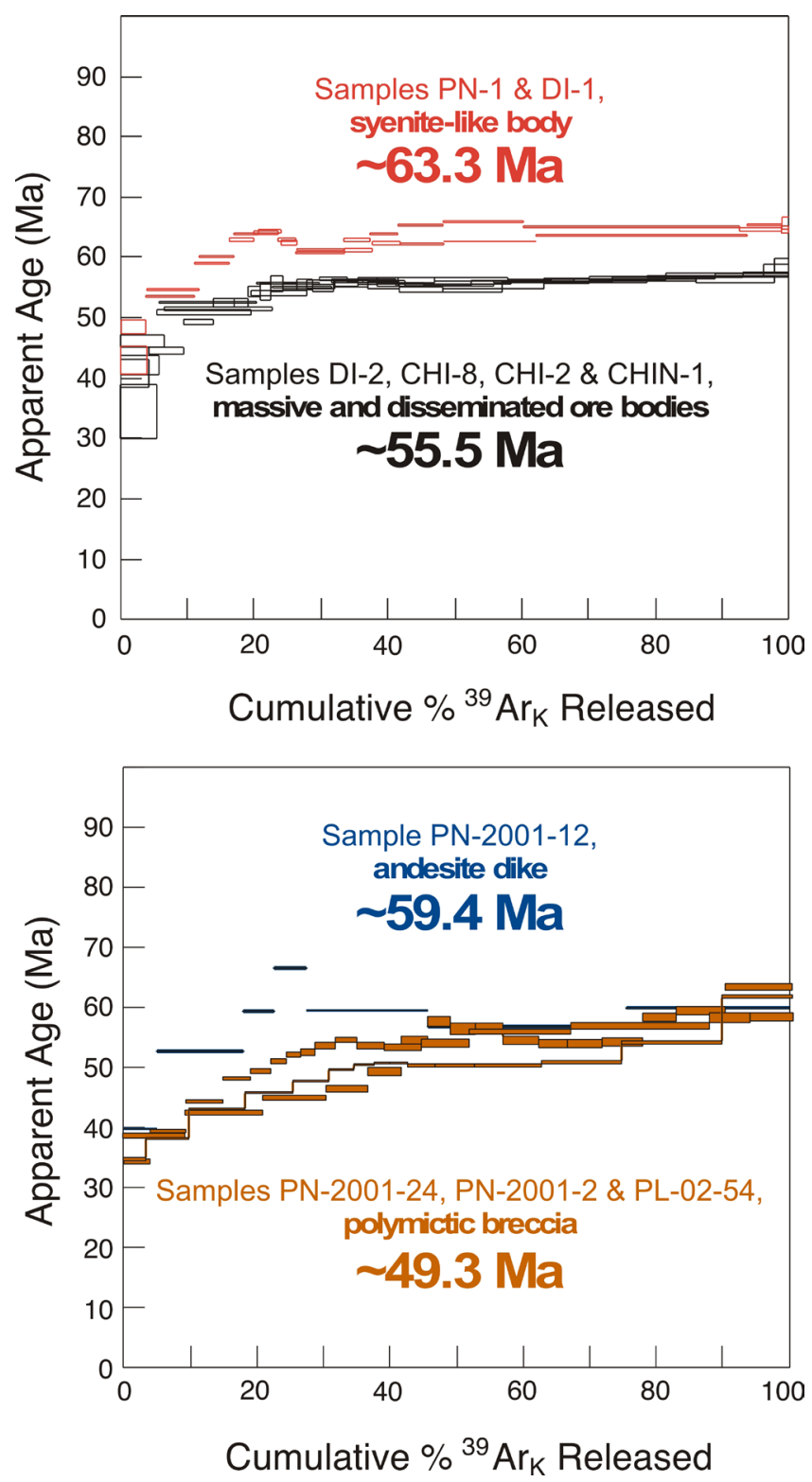

Figure 16 Compilation of the ${ }^{40} \mathrm{Ar} /{ }^{39} \mathrm{Ar}$ plateau age spectra for the potassium feldspar separates from dated associations in the Peña Colorada deposit in this paper. See data and individual plateau and isochron diagrams in Appendices 4 and 5 in Supplementary Material.
Arrayanes prospect, where potassic and propylitic assemblages are subordinate. All general models for IOCG "clan" deposits (e.g., Hitzman et al., 1992; Pollard, 2006; Richards and Mumin, 2013 describe a deeper occurrence for sodic-alteration-dominated rocks than those dominated by potassic alteration (and its low-temperature relative, propylitic alteration; e.g., Corbett and Leach, 1998). Therefore, it is most likely that the deposits at Arrayanes represent a deeper albeit smaller "version" of the Peña Colorada deposit, thus limiting the prospectivenes of the Arrayanes deposit at depth but at the same time favoring the prospectivenes of the Peña Colorada deposit at depth. This would mean that shallower mineraization in the Arrayanes prospect has been eroded. Further, if we accept that "pegmatoid" magnetite + fluorapatite \pm diopside associations were formed as veins in both deposits, their occurrence at Peña Colorada (only visible as sampled fragments that were carried upwards during the formation of the polymictic breccia) implies that a great portion of the original body may still lie deep and concealed (see section 6.3 for a discussion of AFT ages in this association).

\subsection{MINERALOGY AND MINERAL GHEMISTRY: MODEL FOR THE FORMATION OF THE DEPOSITS}

A close temporal and genetic association between gabbro-diorite intrusions and iron oxide-apatite (IOA) mineralization in the area is suggested by the occurrence of magmatic magnetite in such intrusions and the nearly coincidental age between gabbro and magnetite + fluorapatite veins at Arrayanes, whose ages are bracketed by those of the main mineralization event at Peña Colorada (see section 6.3). Such disseminated magnetite is considered to be magmatic in origin because it occurs in such intrusions even in the absence of hydrothermal alteration. Also, relatively high concentrations of $\mathrm{F}$ in apatite (fluorapatite or F-rich chlorapatite or hydroxilapatite) can be associated with the involvement of magmatic-hydrothermal activity in the studied deposits (Zhu and Sverjensky, 1991; Mukherjee et al., 2017). Such a feature 
is further suggested by the correlation between $\mathrm{Ni} / \mathrm{Cr}$ vs. Ti values in magnetite (Dare et al., 2012; Figure 11G). Mg contents in magnetite (between 35 and $1431 \mathrm{ppm}$ ) also suggest a hydrothermal origin, according to Nadoll et al. (2014) . These characteristics agree with several other features that suggesting that the Peña Colorada deposit formed by means of replacement of earlier rocks such as the hosting volcano-sedimentary rocks or garnetites (Tritlla et al., 2003; Camprubí and Canet, 2009; Camprubí and González-Partida, 2017), which would be easily attained by hydrothermal fluids. Pyroxene thermometry in this paper did not permit determination of precise temperatures (possibly less than approximately 300 ${ }^{\circ} \mathrm{C}$ ), but Zürcher et al. (2001) determined temperatures above $400{ }^{\circ} \mathrm{C}$ and up to approximately 500 ${ }^{\circ} \mathrm{C}$, which suggest that the formation of the Peña Colorada deposit was indeed associated with magmatic-hydrothermal processes. The ore-forming fluids in all analyzed associations have high oxygen fugacities (full span of $\log f \mathrm{O}_{2}$ ) calculated from Mn contents in fluorapatite ranges between -10.9 \pm 0.6 and $-10.1 \pm 0.5)$. The magmatic processes that triggered the formation of this deposit also formed skarn (Zürcher et al., 2001) and skarnoid associ-
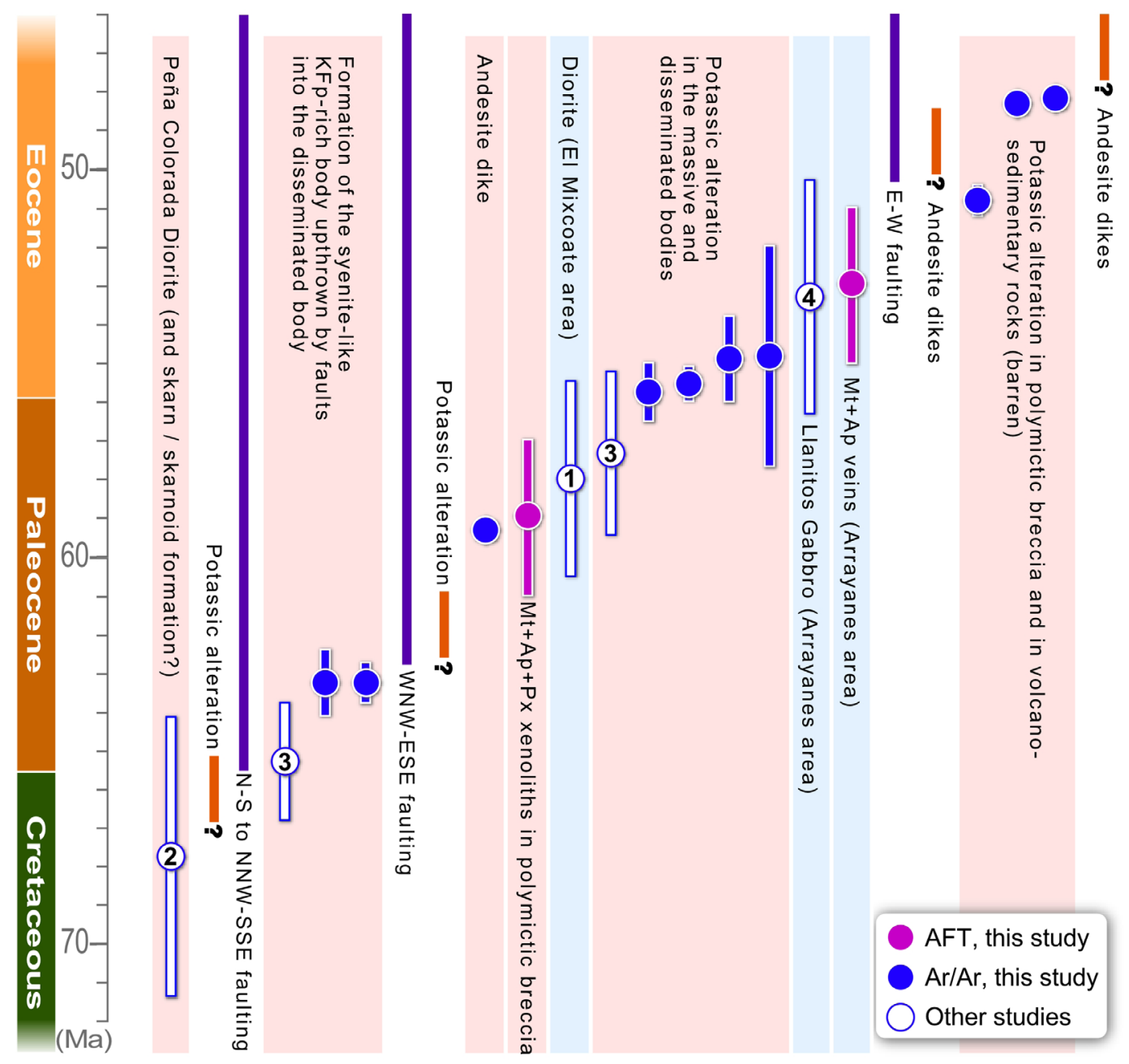

Figure 17 Compilation of available ages in the Peña Colorada mineralized region, and relative position in time of other geological events, such as faulting and undated hypabyssal intrusions. Pink shades denote ages from associations in the Peña Colorada deposit and blue shades denote those of other localities in this region. Circles denote average ages, and the lengths of bars denote standard deviations. Numbers correspond to the following references: (1) Murillo and Torres (1987), (2) Sánchez-Quiroz and Juárez (1988), (3) Tritlla et al. (2003), (4) Solé et al. (2007), all of them K-Ar ages. Key: AFT = fission tracks in apatite. 
Table 4. Summary of ${ }^{40} \mathrm{Ar} /{ }^{39} \mathrm{Ar}$ and apatite fission track (AFT) ages obtained in this study and other relevant ages in the literature for the Peña Colorada and Arrayanes iron oxide deposits and neighboring areas.

\begin{tabular}{|c|c|c|c|c|}
\hline Sample & Mineral & Dating method & Age (Ma) & Mineral association / stage of mineralization \\
\hline$?$ & w.r. & $\mathrm{K}-\mathrm{Ar}$ & $67.6 \pm 3.5$ & Deep-seated diorite in the Peña Colorada area, by Sánchez-Quiroz and Juárez (1988). \\
\hline PN18 & $\mathrm{KF}$ & $\mathrm{K}-\mathrm{Ar}$ & $65.3 \pm 1.5$ & $\begin{array}{l}\text { Syenite-like potassic alteration (of a non-identified intrusive rock) upthrown by faulting into the disseminated body. } \\
\text { Central part of the Peña Colorada deposit (Chinforinazo centro-sur), by Tritlla et al. (2003). }\end{array}$ \\
\hline PN-1 & $\mathrm{KF}$ & ${ }^{40} \mathrm{Ar} /{ }^{39} \mathrm{Ar}$ isochron & $63.26 \pm 0.85$ & $\begin{array}{l}\text { Syenite-like potassic alteration (of a non-identified intrusive rock) upthrown by faulting into the disseminated body. } \\
\text { Central part of the Peña Colorada deposit (Chinforinazo centro-sur). }\end{array}$ \\
\hline DI-1 & $\mathrm{KF}$ & ${ }^{40} \mathrm{Ar} /{ }^{39} \mathrm{Ar}$ isochron & $63.26 \pm 0.52$ & $\begin{array}{l}\text { Potassic alteration patch in the disseminated body. Central part of the Peña Colorada deposit (Chinforinazo centro- } \\
\text { sur). }\end{array}$ \\
\hline ? & $\mathrm{Hb}$ & $\mathrm{K}-\mathrm{Ar}$ & $62.0 \pm 2.5$ & Diorite in the El Mixcuate area, by Murillo and Torres (1987). \\
\hline PN2001-12 & w.r. & ${ }^{40} \mathrm{Ar} /{ }^{39} \mathrm{Ar}$ plateau & $59.39 \pm 0.21$ & Andesite dike. La Encantada area, Peña Colorada. \\
\hline M2 & Ap & $\mathrm{AFT}$ & $59 \pm 2$ & Pegmatoid magnetite + fluorapatite + diopside fragments within the polymictic breccia. La Chula area, Peña Colorada. \\
\hline CHIN & $\mathrm{KF}$ & $\mathrm{K}-\mathrm{Ar}$ & $57.3 \pm 2.1$ & $\begin{array}{l}\text { Fragment of garnetite replaced by potassic alteration within the massive body. Central part of the Peña Colorada } \\
\text { deposit (Chinforinazo centro-sur), by Tritlla et al . (2003). }\end{array}$ \\
\hline CHI-2 & $\mathrm{KF}$ & ${ }^{40} \mathrm{Ar} /{ }^{39} \mathrm{Ar}$ isochron & $55.72 \pm 0.75$ & $\begin{array}{l}\text { Fragment of garnetite replaced by potassic alteration within the massive body. Central part of the Peña Colorada } \\
\text { deposit (Chinforinazo centro-sur). }\end{array}$ \\
\hline CHI-8 & $\mathrm{KF}$ & ${ }^{40} \mathrm{Ar} /{ }^{39} \mathrm{Ar}$ isochron & $55.53 \pm 0.45$ & $\begin{array}{l}\text { Fragment of garnetite replaced by potassic alteration within the massive body. Central part of the Peña Colorada } \\
\text { deposit (Chinforinazo centro-sur). }\end{array}$ \\
\hline DI-2 & $\mathrm{KF}$ & ${ }^{40} \mathrm{Ar} /{ }^{39} \mathrm{Ar}$ isochron & $54.90 \pm 1.1$ & $\begin{array}{l}\text { Fragment of garnetite replaced by potassic alteration within the massive body. Central part of the Peña Colorada } \\
\text { deposit (Chinforinazo centro-sur). }\end{array}$ \\
\hline CHIN-1 & $\mathrm{KF}$ & ${ }^{40} \mathrm{Ar} /{ }^{39} \mathrm{Ar}$ isochron & $54.84 \pm 2.83$ & $\begin{array}{l}\text { Fragment of garnetite replaced by potassic alteration within the massive body. Central part of the Peña Colorada } \\
\text { deposit (Chinforinazo centro-sur). }\end{array}$ \\
\hline ? & $\mathrm{Pl}$ & $\mathrm{K}-\mathrm{Ar}$ & $53.3 \pm 3.0$ & Llanitos gabbro in the Arrayanes area, by Solé et al. (2007). \\
\hline M1 & Ap & $\mathrm{AFT}$ & $53 \pm 2$ & Pegmatoid magnetite + fluorapatite vein. Central part of the Arrayanes area. \\
\hline PN2001-24 & $\mathrm{KF}$ & ${ }^{40} \mathrm{Ar} /{ }^{39} \mathrm{Ar}$ isochron & $50.70 \pm 0.40$ & $\begin{array}{l}\text { Aplite fragment affected by potassic alteration within the polymictic breccia (middle part of the breccia). Central part } \\
\text { of the Peña Colorada deposit (Chinforinazo). }\end{array}$ \\
\hline PN02-54 & $\mathrm{KF}$ & ${ }^{40} \mathrm{Ar} /{ }^{39} \mathrm{Ar}$ isochron & $48.30 \pm 0.30$ & $\begin{array}{l}\text { Barren skarnoid replaced by potassic alteration adjacent to the disseminated body. Outcrop by the side of the road } \\
\text { before the entrance to the Peña Colorada mine premises. }\end{array}$ \\
\hline PN2001-2 & $\mathrm{KF}$ & ${ }^{40} \mathrm{Ar} /{ }^{39} \mathrm{Ar}$ isochron & $48.18 \pm 0.16$ & $\begin{array}{l}\text { Aplite fragment affected by potassic alteration within the polymictic breccia (lower part of the breccia). La Chula } \\
\text { area, Peña Colorada. }\end{array}$ \\
\hline
\end{tabular}

Key: $\mathrm{Ap}=$ fluorapatite; $\mathrm{Hb}=$ hornblende; $\mathrm{KF}$ = potassium feldspar; $\mathrm{PI}=$ plagioclase; $\mathbf{w} . \mathrm{r}$. = whole rock.

ations (Figure 18). Therefore, these deposits can be ascribed as proximal-to-source types (iron skarn and Kiruna types) in association with calc-alkaline magmas in the classification of Corriveau (2007). Based upon the geological characteristics of the Peña Colorada deposit, recent papers have acknowledged its inclusion in the IOCG "clan" of deposits (e.g., Tritlla et al., 2003; Camprubí and Canet, 2009; Camprubí and González-Partida, 2017), thus ruling out previous genetic models. Therefore, it was expected that the chemistry of magnetite in this deposit would have been in accordance with the compositional fields that correspond to IOCG and Kiruna-type deposits in conventional discrimination diagrams, which is not the case (Figures $11 \mathrm{~A}$ and $\mathrm{B}$ ). $\mathrm{TiO}_{2}$ contents in magnetite (up to $10.355 \mathrm{wt} . \%$ ) are much higher in the Peña Colorada deposit than in the existing wealth of data from IOCG and Kiruna-type deposits (Dupuis and Beaudoin, 2011; Nadoll et al., 2014). The relatively high $\mathrm{Ti}$ content in the Peña Colorada and Arrayanes deposits is further manifested by the occurrence of titanite in their mineral associations (Figures 4 and 7). Such endowment in $\mathrm{Ti}$ is the main factor that pushes the magnetite composition in this deposit into the recognized compositional fields for several types of deposits, namely metalliferous porphyries and skarns, IOCG and Kiruna-type deposits, and even into the field for Fe-Ti-V deposits in the discrimination diagrams. The burden of present knowledge it not in agreement with Peña Colorada (and its age) to share much affinity with Fe-Ti-V deposits. In addition, the parental magmatism to the Peña Colorada and Arrayanes deposits can be characterized (along with the data by Zürcher et al., 2001; Corona-Esquivel and Henríquez, 2004) as gabbro-dioritic, tholeiitic, oxidized, and 
1) Before $\sim 67.6 \mathrm{Ma}$

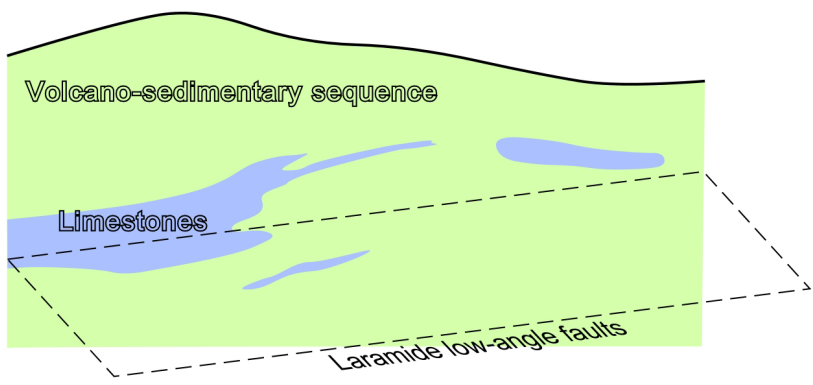

2) $\sim 67.6 \mathrm{Ma}$

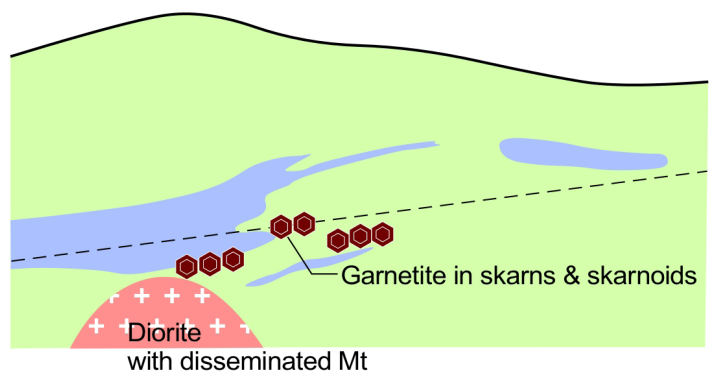

5) $\sim 59.39 \mathrm{Ma}$

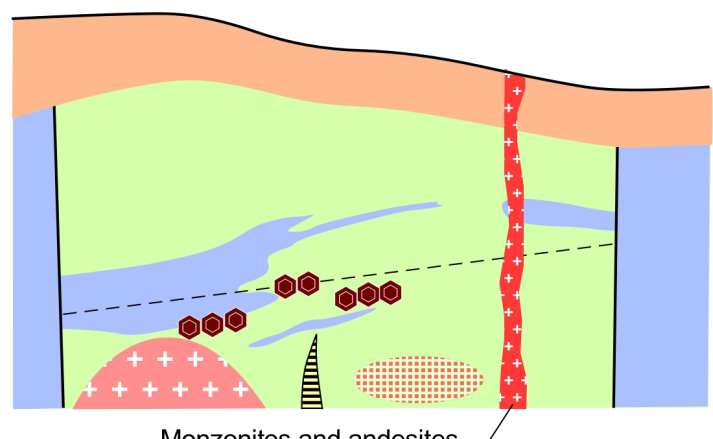

Monzonites and andesites

NW-SE

3) Between $\sim 67.6$ and $\sim 63.26 \mathrm{Ma}$

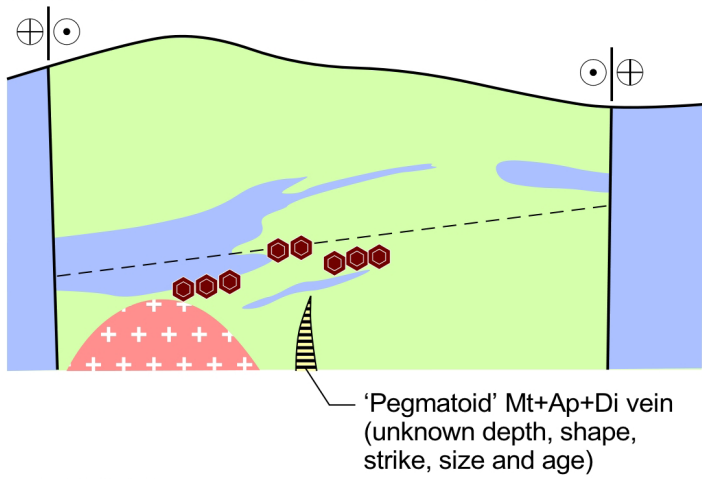

6) Between $\sim 55.72$ and $\sim 54.84 \mathrm{Ma}$

4) $\sim 63.26 \mathrm{Ma}$

nn depth, shape
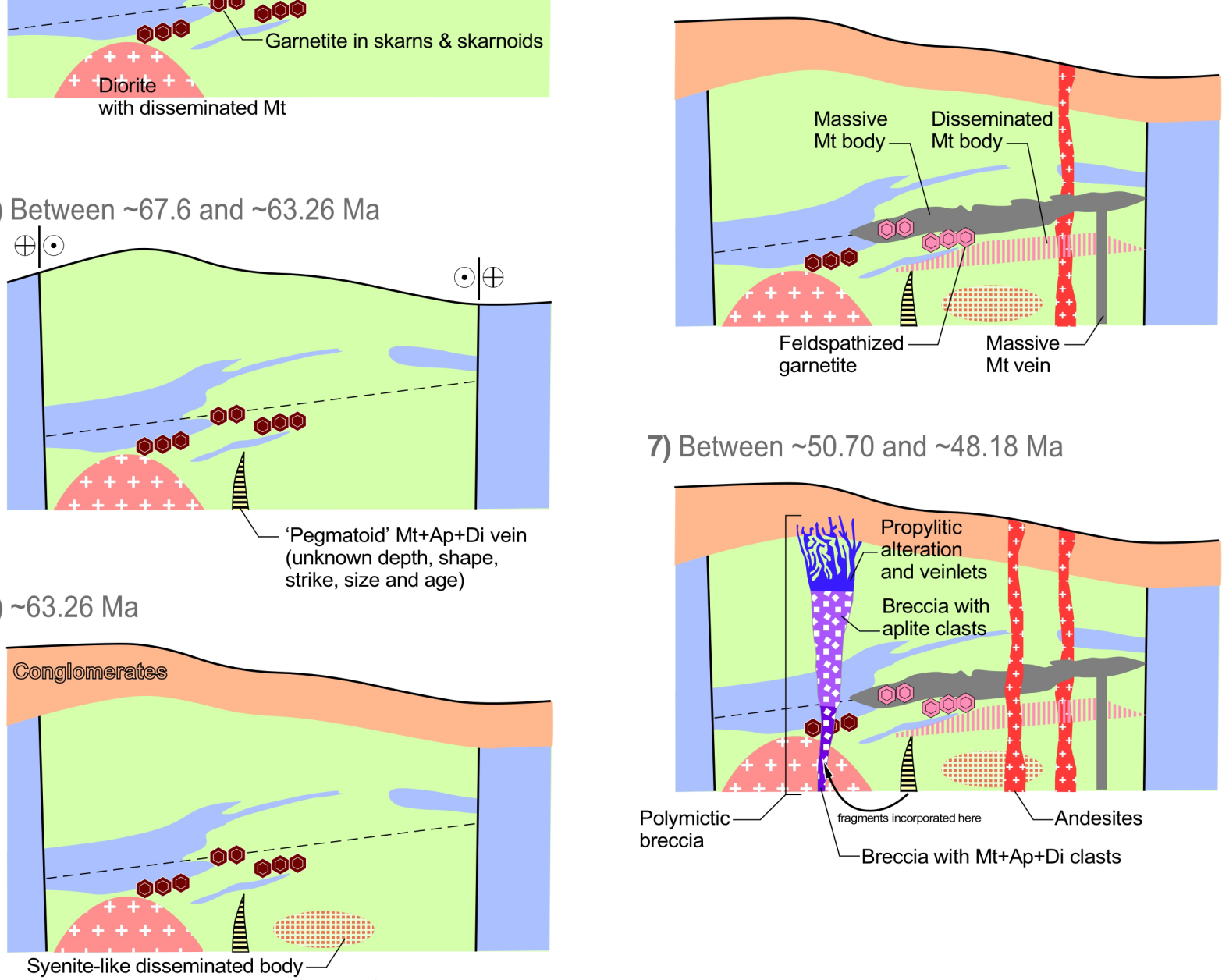

7) Between $\sim 50.70$ and $\sim 48.18 \mathrm{Ma}$

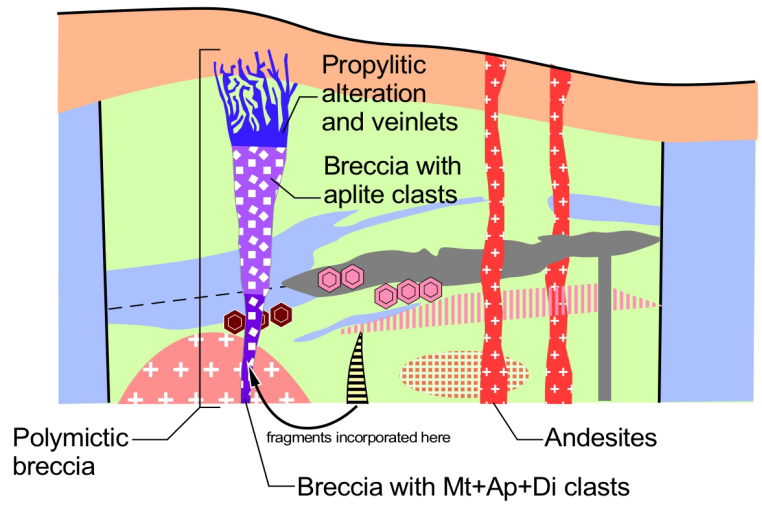

Syenite-like disseminated body

(unknown depth, shape, strike and size)

Figure 18 Schematic representation (not to scale) of the history of the Peña Colorada deposit in a NW-SE cross-section located between the yellow arrows in Figure 2. The occurrence of most structural domains is omitted for the sake of clarity. Key: Ap = fluorapatite, Di = diopside, $\mathrm{Mt}=$ magnetite . 
primitive, although it also includes felsic petrologic terms. Such character is in stark contrast with that expected for sulfide-rich porphyries and skarns, which would be neatly monzonitic-granodioritic, calc-alkaline to alkaline, relatively reduced, and evolved. Therefore, discrimination diagrams in Figure $11 \mathrm{~A}$ and B may benefit from some refining once systematic efforts in determining representative chemical compositions of magnetite are undertaken in different types of magnetite-bearing deposits elsewhere.

REE patterns in fluorapatite samples of the study area are similar to those from Cerro de Mercado and Kiruna-type deposits (Belousova et al., 2002; Mao et al., 2016) and whole-rock patterns in other IOCG "clan" deposits (e.g., Nold et al., 2014). The obtained SLREE and SHREE contents in fluorapatite from the Peña Colorada and Arrayanes deposits (LLREE range between 2058 and 6066 ppm, and $\Sigma$ HREE range between 268 and 776 ppm; Table 3 and Appendix 3 in Supplementary Material) also correspond to "typical" ranges for IOCG and Kiruna-type deposits (Belousova et al., 2002; Mao et al., 2016). These characteristics allows us to soundly place the magmatic-hydrothermal iron oxide deposits of the Peña Colorada area among the IOCG "clan," despite past controversies (see Camprubí and Canet, 2009; Camprubí and González-Partida, 2017). However, high Ce contents in fluorapatite in the Peña Colorada and Arrayanes deposits (up to 4640 ppm) are uncommon in other IOCG and Kiruna-type deposits and, for that matter, in other types of deposits (see Figure 6 in Mao et al., 2016; Mukherjee et al., 2017). Ce/Ce* values in the Peña Colorada deposit and the Arrayanes prospect range between 4 and 5, whereas they are commonly $<1$ in IOCG and Kiruna-type deposits, and $<2$ in other magmatic-hydrothermal types of deposits, including carbonatites (see Mao et al., 2016; Mukherjee et al., 2017). High Ce contents in IOCG "clan" deposits are normally associated with the occurrence of Ce-rich minerals like allanite, monazite, or xenotime rather than apatite alone (e.g., Harlov et al., 2016; Jonsson et al., 2016). Conversely, Eu con- tents in fluorapatite in this study are much lower than in other magmatic-hydrothermal deposits of either type: $\mathrm{Eu} / \mathrm{Eu}^{*}$ values in the Peña Colorada deposit and the Arrayanes prospect range between 0.03 and 0.09 , whereas they range between 0.9 and 1.3 in IOCG and Kiruna-type deposits, are up to 1.7 in other magmatic-hydrothermal types of deposits, and are significantly elevated in carbonatites (see Mao et al., 2016; Mukherjee et al., 2017). Consequently, high Ce and low Eu contents in fluorapatite deserve further attention both in this mineralized region and in general for IOCG "clan" deposits, in particular with regard to their petrogenetic significance.

\subsection{AGES OF MINERALIZATION EVENTS}

The events that led to the formation of the multistage Peña Colorada and Arrayanes magmatichydrothermal iron oxide (MHIO) deposits began in the latest Cretaceous (Maastrichtian) and ended in the earliest Eocene (Ypresian). These deposits are bracketed by the age of their purported initial "parental" diorite intrusive at 67.6 $\pm 3.5 \mathrm{Ma}$ and the youngest age of potassic alteration associated with the polymictic breccia at $48.18 \pm 0.16 \mathrm{Ma}$ (Figure 17 and Table 4). All the major mineralization events were apparently predated by neighboring magmatic events that include diorites or gabbros, and also by changes in strike of structural styles (Figures 8 and 9), or changes in the dominant stress fields regionally. The ages of such structural, magmatic, and mineralizing events overlap within the ranges of uncertainty of the available ages (Figure 17 and Table 4), and thus they can be grouped into the following episodes:

1. the intrusion of the $67.6 \pm 3.5 \mathrm{Ma}$ Peña Colorada diorite triggered the formation of garnetites in skarn or skarnoid associations and partially overlaps the ages obtained for the syenite-like body, and could be coeval or predate the N-S to NNW-SSE faulting;

2. the N-S to NNW-SSE faulting predates the formation of the $\sim 63.26 \mathrm{Ma}$ syenite-like potassic alteration of a non-identified intru- 
sive rock (diorite?) that was later upthrown by faulting into the disseminated body, which is postdated by WNW-ESE faulting;

3. the $62.0 \pm 2.5 \mathrm{Ma} \mathrm{El}$ Mixcuate diorite is predated by WNW-ESE faulting and is essentially the same age as the $59.39 \pm 0.21 \mathrm{Ma}$ andesite dikes in Peña Colorada; the diorite predates the 55.72 - 54.84 Ma main mineralization event, which consists of stratabound massive and disseminated bodies that are hosted by volcano-sedimentary rocks;

4. the latter assemblage of ages, in turn, overlaps with the $53.3 \pm 3.0 \mathrm{Ma}$ Llanitos gabbro in the Arrayanes area, and this gabbro overlaps with the $53 \pm 2$ Ma pegmatoid magnetite + fluorapatite veins at Arrayanes and with part of the $50.70-48.18 \mathrm{Ma}$ potassic alteration confined to the rock fragments in the polymictic breccia;

5. the polymictic breccia was predated by a new change in strike of faulting $(\mathrm{E}-\mathrm{W})$; a $48.30 \pm$ $0.30 \mathrm{Ma}$ section of barren potassic alteration outside the polymictic breccia is essentially the same age as the youngest age that was obtained for the breccia; therefore, the potassic alteration assemblage is associated with the breccia as well;

6. reactivation of WNW-ESE faults and later NE-SW faults affect all the mineralized bodies; the NE-SW faults originated the Minatitlán graben, thus obscuring the structural continuity between the Peña Colorada and Arrayanes areas through the Aztlán fault.

Figure 18 illustrates a simplified graphic representation of these episodes of structural, magmatic, and mineralizing events and other key events.

The $59 \pm 2 \mathrm{Ma}$ apatite fission track (AFT) age obtained in a fragment of "pegmatoid" magnetite plus fluorapatite plus diopside mineralization within the polymictic breccia also overlaps with group of ages number 3, although the breccia in which these occur is interpreted to be a part of the polymictic breccia, which is approximately $9 \mathrm{Myr}$ younger. Any explanation must account for a possible thermal resetting during the emplacement of the polymictic breccia or another hydrothermal event. The latter could reasonably be associated with the hypabyssal activity represented by 59.39 $\pm 0.21 \mathrm{Ma}$ andesite dikes. A plausible explanation for the age disagreement between the pegmatoid fragments and the potassic alteration in the polymictic breccia would be that there are not one but two different breccias (or a very long-lived one with several reactivation periods), with similar strike albeit different ages. If this were the case, the older part of the breccia with the pegmatoid fragments would then be older than the obtained $59 \pm$ 2 Ma AFT age, due to thermal resetting. Following this rationale, the original pegmatoid body from which the fragments originally came (similar to the magnetite plus fluorapatite veins in the Arrayanes prospect) would then be even older, perhaps to be protracted to the earliest stages of formation of the Peña Colorada deposit at approximately 67.7 or 63.26 Ma (Figure 18).

The various styles of iron oxide-apatite (IOA) mineralization in the Arrayanes prospect are closely associated with the local gabbro (Llanitos gabbro), diorite, and microgranodiorite hypabyssal bodies. The Llanitos gabbro was dated at $53.3 \pm 3.0 \mathrm{Ma}$ (Solé et al., 2007) whereas fluorapatite in "pegmatoid" magnetite plus fluorapatite veins was dated by AFT at $53 \pm 2 \mathrm{Ma}$ (Figure 14). Both ages are consistent and suggest a close association between magmatism and IOA mineralization. As both magmatism and mineralization are associated with WNW-ESE faulting alone and predate the $\mathrm{E}-\mathrm{W}$ structural domain, it is likely that the entirety of IOA mineralization events in the Arrayanes prospect are bracketed by a period that ranges between 54.84 and $50.70 \mathrm{Ma}$ (see section 6.4), which is the period in which the main mineralized bodies at Peña Colorada were formed (Figure 17). Therefore, the 54.84 to $50.70 \mathrm{Ma}$ period would represent the peak event for ore formation in the region. Also, despite the difficulty in associating mineralization events with parental hypabyssal bodies at Peña Colorada, the close association in time between IOA mineralization and the Llanitos gabbro at Arrayanes, which are essentially coeval 
with the most productive mineralization events at Peña Colorada (Figure 17), allow us to conclude that (1) both the Peña Colorada and Arrayanes IOA deposits are genetically and temporally associated, (2) IOA deposits in the region are associated with the emplacement of iron oxide-bearing tholeiitic (primitive) magmas, and (3) such processes peaked between the end of the Paleocene and the beginning of the Eocene.

The ${ }^{40} \mathrm{Ar} /{ }^{39} \mathrm{Ar}$ and apatite fission track ages obtained in this study for the Peña Colorada and Arrayanes deposits (Figure 17 and Table 4 ), along with previously existing data, imply an approximately $19 \mathrm{Myr}$ (with regard to average ages only) to approximately $23 \mathrm{Myr}$ (with regard to the full span of standard deviations) period of mineralization. Therefore, Peña Colorada had the longest-lasting formation of any $\mathrm{MHIO}$ deposit in Mexico (and for that matter, of any other type of deposit) in the present reckoning by means of high-resolution age determinations. However, such period is dwarfed by the approximately 80 Myr period that was determined for the episodic MHIO mineralization in the giant Marcona-Mina Justa district in Perú (Chen et al., 2010, and references therein ). High-resolution systematic dating endeavors in the full panoply of MHIO deposits (with variable styles and sizes of mineralization, geodynamic settings, and ages) show that their formation spanned highly variable periods of time. Periods of formation of MHIO deposits wider than in Peña Colorada were found in deposits like Olympic Dam, Prominent Hill (appoximately 35 to 30 Myr; Apukhtina et al., 2017; Bowden et al., 2017) and Cloncurry in Australia (approximately 30 Myr; Babo et al., 2017), Mantoverde in Chile (approximately 33 Myr; Barra et al., 2017), and Kiruna in Sweden (approximately $30 \mathrm{Myr}$; Smith et al., 2009; Martinsson et al., 2016; Westhues et al., 2016). Narrower periods of formation were found in deposits like Candelaria in Chile (approximately 15 Myr; Barra et al., 2017), Rakkurijärvi in Sweden (approximately $10 \mathrm{Myr}$; Smith et al., 2007), Salobo in Brazil (approximately 12? Myr; deMelo et al., 2017), Bafq in Iran (approximately
12 Myr; Stosch et al., 2011), or the Turgai belt in Kazakhstan (approximately 10 Myr; Hawkins et al., 2017). Special cases are presented by the Lala deposit in China (Chen and Zhou, 2014; Zhu et al., 2018) and Sossego in Brazil (Moreto et al., 2015), with several mineralization events that span nearly approximately 100 to hundreds of Myr All in all, the Peña Colorada deposit is part of the global trend for MHIO deposits to be significantly longer lived than other magmatic-hydrothermal deposit types. This persistence through time in MHIO-triggering magmatism in a given region or set of structures is still in need of specific tectonomagmatic research on a global scale.

At a semi-regional perspective (Colima-Jalisco-Michoacán region), deposits similar to the Peña Colorada that were formed at about the same time are El Encino and Agua Dulce. The intrusive rocks at El Encino yielded K-Ar (whole rock) ages at $65.0 \pm 3.3 \mathrm{Ma}$, although magnetite-bearing gabbros were dated at $93.1 \pm$ 4.7 Ma (referred by Corona-Esquivel and Henríquez, 2004), and it remains uncertain which intrusive is most likely to have produced the iron oxide orebodies. A similar case to the El Encino deposit is Aquila in Michoacán (Figure 1). The "parental" diorite intrusions to the Aquila deposit (Mapes-Vázquez, 1956) were dated at $98.6 \pm 4.8$ Ma (K-Ar, whole rock; Ruvalcaba-Ruiz, 1983) although Camprubí (2009, 2013) reported ages of 63.0-61.24 Ma for intrusions that might also be associated with iron deposition; it would then be desirable to reassess the ages of country rocks. Tritlla et al. (2003) reviewed the ages of intrusive rocks in the Colima-Jalisco-Michoacán region and reported a range of ages between about 100 to 55 Ma for the intrusion of granites, granodiorites, monzogranites, gabbros, diorites, and tonalities. These episodes of intrusion indicate an ill-defined complex tectonomagmatic scenario that requires further attention (Camprubí, 2017) but that is similar to the evolution of the Andean Coastal Ranges, where an attenuated crust and intra-arc extension favored the formation of IOCG "clan" deposits until crustal buildup during compression 
terminated magmatic-hydrothermal activity (e.g, Sillitoe, 2003; Sillitoe and Perelló, 2005). The descriptions of iron oxide mineralization in SW Mexico include the presence of gabbroic, dioritic, alaskitic, and/or monzonitic intrusions (GonzálezReyna, 1956; Mapes-Vázquez, 1956; Vélez-López et al., 1977; Ruvalcaba-Ruiz, 1983; Corona-Esquivel and Henríquez, 2004; Arroyo-Domínguez, 2009; Camprubí, 2009, 2013; Camprubí and González-Partida, 2017). Such features are shared with MHIO deposits elsewhere in similar magmatic calc-alkaline contexts along the western cordilleras of the Americas (e.g, Camprubí, 2017). Despite the likely association of gabbros and diorites with $\mathrm{MHIO}$ deposits, ages > $90 \mathrm{Ma}$ for such rocks do not agree well with the age distribution of MHIO deposits in SW Mexico (see Camprubí, 2013, 2017; Camprubí and González-Partida, 2017) unless they represent a new metallogenic province or epoch. As suggested by this geochronological study of the Peña Colorada deposit and the regional distribution of similar deposits, the likeliest age for MHIO deposits in SW Mexico is Paleocene.

\subsection{AGES OF STRUGTURAL DOMAINS}

Due to the excellent correlation between the regional and Peña Colorada structural domains (Figures 8 and 9), the chronology of mineralization and structural events in the study area (Figure 17) can be extended from a local to a regional scale, at least for the initiation of structural domains. Reactivation of structural domains, detected locally, has yet to be documented at a regional scale. The initiation of structural domain 1 (N-S to NNW-SSE) postdates the intrusion of the Peña Colorada diorite and predates the formation of the oldest mineralization event, and thus it can be bracketed between 67.6 and $63.26 \mathrm{Ma}$ (Figure 18). Also, since the $\mathrm{N}-\mathrm{S}$ system is older than the conglomerates of the Cerro de la Vieja Formation, this formation would not be older than 67.6 Ma. Otherwise, those rocks would not belong to that formation, a possibility that needs further assessment. A possible Maastrichtian age for the conglomerates disagrees with previous correlations that suggested a Cenomanian age (see Tritlla et al., 2003). Therefore, the deposition of the conglomerates formerly attributed to the Cerro de la Vieja Formation would be nearly contemporaneous with the formation of the earliest stage of mineralization in the Peña Colorada deposit (Figure 18). In addition, such a scenario implies that at least the massive and disseminated ore bodies and the polymictic breccia were formed at relatively shallow depths, probably only a few hundreds of meters (see Figure 5). The initiation of structural domain 2 (WNW-ESE) postdates the oldest mineralization event and predates the dated andesite dike, and thus it can be bracketed between 63.26 and $59.39 \mathrm{Ma}$. The initiation of structural domain $3(\mathrm{E}-\mathrm{W})$ postdates the formation of the massive and disseminated ore bodies and predates the polymictic breccia, and thus it can be bracketed between 54.84 and 50.70 Ma. The initiation of structural domain 4 (WNWESE to NW-SE), to which the basement-derived Tamazula fault zone belongs (Figure 8), postdates the formation of the polymictic breccia, and thus it would be younger than $48.18 \mathrm{Ma}$. The age of the initiation of the structural domain 5 (NE-SW; still active at present), to which the basementderived Las Cumbres fault zone belongs, remains undetermined. Possible relative ages for numerous detected reactivations are also uncertain.

Additionally, the location of the Peña Colorada and Arrayanes mineralized areas next to two major, long-lived, multi-reactivated, cryptic structural corridors (the basement-derived Tamazula and Las Cumbres fault zones; Figure 8) may represent another instance for the important role that such corridors play in concentrating the emplacement of magmas and their associated ore deposits (see Nieto-Samaniego et al., 2005, 2007; Camprubí, 2013, 2017). Such a hypothesis is supported by the structural analysis in this paper, which indicates that domain $1(\mathrm{~N}-\mathrm{S})$ was initially associated with the reactivation of older faults in the basement for the Cretaceous volcano-sedimentary sequence, 
which might have exerted some control on the emplacement of the 67.6 Ma Peña Colorada diorite.

\section{Conclusions}

The Peña Colorada iron oxide-apatite (IOA) deposit has a multi-stage character. Each significant stage of mineralization in the Peña Colorada deposit is associated with diorite, gabbro, and monzogranite intrusions within a dominantly calc-alkaline suite with episodic tholeiitic affinity. The emplacement of intrusive bodies and stages of mineralization followed critical changes in the regional stress fields, as marked by changes in strike of faulting. The emplacement of the main stage of mineralization was controlled by lowangle Laramide faults within Cretaceous volcanosedimentary rocks that impart a semi-stratabound character to the mineralization. All mineralization events in Peña Colorada are enveloped by pervasive potassic alteration assemblages.

Five structural domains were identified both at regional and local scales: (1) N-S to NNW-SSE, (2) WNW-ESE, (3) E-W, (4) NW-SE, and (5) NESW. Domain 1 at Peña Colorada predated the syenite-like disseminated mineralization, domain 2 predated the main stage of mineralization (massive and disseminated bodies), and domain 3 predated the polymictic breccia. It is possible that the location of this deposit was determined by reactivated faults in the basement, as it occurs near two major basement-derived fault zones; further research that assesses such possibility would be required.

The Peña Colorada deposit and neighboring mineralized areas share several geologic characteristics in terms of the mineralogy and geometry of their mineralized bodies, or the chemical composition of fluorapatite. However, potassic alteration is widespread at Peña Colorada (and the La Fundición prospect), whereas it is incipiently developed at the Arrayanes prospect, where sodic alteration is dominant. Also, "pegmatoid" magnetite plus fluorapatite associations occur at Arrayanes as veins, whereas very similar "pegmatoid" magnetite plus fluorapatite plus diopside associations in Peña Colorada are only visible as fragments in a polymictic breccia, possibly sourced from deeper veins. These characteristics support the notion that the Arrayanes prospect represents a deeper portion of the deposit than Peña Colorada. Consequently, exploration endeavors in the latter are still promising but not so much in the former.

Parental intrusive rocks to the IOA deposits in the study area are well displayed in the Arrayanes prospect alone. These are the Llanitos gabbro (whose age is nearly the same as the AFT age in a magnetite + fluorapatite vein), diorite, and microgranodiorite, and all of which have disseminated magmatic magnetite. The highest magnetite content in these rocks was found in the contacts between gabbro and diorite. The contacts between intrusive rocks in the area are complex and suggest the existence of mixing or mingling processes, especially between gabbros and diorites.

The mineralogy and mineral chemistry of magnetite and fluorapatite in these deposits are compatible with a magmatic-hydrothermal origin under high $\mathrm{O}_{2}$ fugacities, and this deposit shares many geochemical traits with Kiruna-type and other magmatic-hydrothermal iron oxide deposits (MHIO, or IOCG “clan"). REE patterns and ¿LREE and $\Sigma$ HREE values in fluorapatite of these deposits are typical for Kiruna-type and IOCG deposits. In contrast, the studied deposits differ from the rest of $\mathrm{MHIO}$ deposits in their comparatively higher $\mathrm{Ti}$ contents in magnetite, and higher Ce contents and lower Eu contents in fluorapatite.

Therefore, the deposits of the Peña Colorada can be ascribed within MHIO or IOCG "clan" deposits that are proximal to the magmatic source, specifically between skarn-related and Kiruna-type deposits. Based on the conventional models for this family of ore deposits, the Peña Colorada deposit would represent the upper part of all possible ranges of depth due to (1) the consistent association of all stages of mineralization 
with potassic alteration (with feathery aggregates of potassium feldspar) and propylitic assemblages; (2) the occurrence of mutual replacements between magnetite and hematite (martitization and mushketovitization; Figures $3 \mathrm{E}$, and $6 \mathrm{~B}$ and C); (3) the occurrence of diopside that was formed at less than approximately $300{ }^{\circ} \mathrm{C}$ in any stage of mineralization; and (4) the shallow environment of formation, in this case deduced from a thin sedimentary cover onto the host Cretaceous volcano-sedimentary sequence.

The formation of iron oxide deposits in the study area (latest Cretaceous to earliest Eocene in age) spans at least approximately 19 to $23 \mathrm{Myr}(67.6$ \pm 3.5 to $48.18 \pm 0.30 \mathrm{Ma}$ ), as revealed by extensive ${ }^{40} \mathrm{Ar} /{ }^{39} \mathrm{Ar}$ and AFT dating. The main stage of mineralization at Peña Colorada was dated at approximately $55 \mathrm{Ma}$. The total age span for the formation of this deposit, however prolonged, is not an exception for sizeable ore deposits of this kind. However, the likeliest range of ages for formation of the Arrayanes prospect would reasonably be 54.84 to $50.70 \mathrm{Ma}$.

Incidentally, the relations between structural domains, host rocks, and the ages of mineralization events in the Peña Colorada deposit indicate that the conglomerates attributed to the Cerro de la Vieja Formation are not older than 67.6 Ma. Also, the local structural domains determined in this study can be correlated at a regional scale, and their ages can be bracketed in relation with the ages of mineralization events in the Peña Colorada deposit.

The regional tectonomagmatic setting during the formation of these IOA deposits, however ill defined, is similar to the case of Andean IOCG "clan" deposits. That is, the "parental" gabbrodioritic, tholeiitic, oxydized and primitive magmatism is compatible with intra-arc extension that was terminated during the Eocene as continental crust thickened.

\section{Acknowledgements}

This study was financed by means of the CONACYT grants 46473 and 155662 and the PAPIIT-UNAM grants IN110810, IN117800 and IN103807. The authors wish to thank Michael Kunk for providing access and guidance to perform the ${ }^{40} \mathrm{Ar} /{ }^{39} \mathrm{Ar}$ geochronology studies at the U.S. Geological Survey Thermochronology Lab in Denver, Colorado. The mineral chemistry data are taken from the BSc dissertation of Jorge A. Aguilar-Hernández, whose help in that piece of research is cordially thanked. Assistance for the mineral chemistry and geochemical analyses was kindly provided by Xavier Llovet (Universitat de Barcelona), Carlos Linares, Carlos Ortega, and Elena Lounejeva (UNAM). The structural analysis and ${ }^{40} \mathrm{Ar} /{ }^{39} \mathrm{Ar}$ ages in this paper were preliminarily mentioned by Camprubí et al.(201 1) and Camprubí (2013). Peter Schaaf is thanked for authorizing the use of some pictures that were originally published in the Revista Mexicana de Ciencias Geológicas. Formal reviews were conducted by Carl E. Nelson and Hildebrando Leal, whose comments helped to improve this paper. Also, Tom Musselman went through a thorough review of English language in this paper that greatly improved its correctness and readability.

\section{References}

Abdullin, F., Solé, J., Solari, L., 2014, Datación mediante trazas de fisión y análisis multielemental con LA-ICP-MS del fluorapatito de Cerro de Mercado (Durango, México): Revista Mexicana de Ciencias Geológicas, 31, 395-406. 
Alexander, E.C. Jr., Mickelson, G.M., Lanphere, M.A., 1978, Mmhb-1: a new ${ }^{40} \mathrm{Ar} /{ }^{39} \mathrm{Ar}$ dating standard, in Zartman, R.E. (ed.), Short papers of the fourth international conference, geochronology, cosmochronology, and isotope geology: U.S. Geological Survey Open-File Report, 78-701, 6-8.

Apukhtina, O.B., Kamenetsky, V.S., Ehrig, K., Kamenetsky, M.B., Maas, R., Thompson, J., McPhie, J., Ciobanu, C.L., Cook, N.J., 2017, Early, deep magnetite-fluorapatite mineralization at the Olympic Dam Cu-U$\mathrm{Au}-\mathrm{Ag}$ deposit, South Australia: Economic Geology, 112, 1531-1542.

Arroyo-Domínguez, L.M., 2009, Yacimiento El Volcán, Sonora, in Glark, K.F., SalasPizá, G., and Cubillas-Estrada, R., (eds.), Geología económica de México, $2^{\text {a }}$ edición: Servicio Geológico Mexicano - Asociación de Ingenieros de Minas, Metalurgistas y Geólogos de México, 888-891.

Babo, J., Spandler, C., Oliver, N.H.S., Brown, M., Rubenach, M.J., Creaser, R.A., 2017, The high-grade Mo-Re Merlin deposit, Cloncurry district, Australia: Paragenesis and geochronology of hydrothermal alteration and ore formation: Economic Geology, 112, 397-422.

Bandy, W.L., Michaud, F., Bourgois, J., Calmus, T., Dyment, J., Mortera-Gutiérrez, C.A., Ortega-Ramírez, J., Pontoise, B., Royer, J.Y., Sichler, B., Sosson, M., Rebolledo-Vieyra, M., Bigot-Cormier, F., Díaz-Molina, O., Hurtado-Artunduaga, A.D., Pardo-Castro, G., Trouillard-Perrot, G., 2005, Subsidence and strike-slip tectonism of the upper continental slope off Manzanillo, Mexico: Tectonophysics, 398, 115-140.

Barra, F., Reich, M., Selby, D., Rojas, P., Simon, A., Salazar, E., Palma, G., 2017, Unraveling the origin of the Andean IOCG clan: A Re-Os isotope approach: Ore Geology Reviews, 81, 62-78.
Belousova, E.A., Griffin, W.L., O'Reilly, S.Y., Fisher, N.I., 2002, Apatite as an indicator mineral for mineral exploration: Trace element compositions and their relationship to host rock type: Journal of Geochemical Exploration, 76, 45-69.

Bowden, B., Fraser, G., Davidson, G.J., Meffre, S., Skirrow, R., Bull, S., Thompson, J., 2017, Age constraints on the hydrothermal history of the Prominent Hill iron oxide coppergold deposit, South Australia: Mineralium Deposita, 52, 863-881.

Camprubí, A., 2009, Major metallogenic provinces and epochs of Mexico: SGA News, 25, 1-21.

Camprubí, A., 2013, Tectonic and metallogenic history of Mexico, in Colpron, M., Bissig, T., Rusk, B.G., Thompson, J.F.H., (eds.), Tectonics, metallogeny, and discovery: the North American Cordillera and similar accretionary settings: Society of Economic Geologists, Special Publication, 17, 201-243.

Camprubí, A., 2017, The metallogenic evolution in Mexico during the Mesozoic, and its bearing in the Cordillera of Western North America: Ore Geology Reviews, 81P3, 1193-1214.

Camprubí, A., Canet, C., 2009, Comment to "Berthierine and chamosite hydrothermal: genetic guides in the Peña Colorada magnetite-bearing ore deposit, Mexico": Earth Planets and Space, 61, 291-295.

Camprubí, A., González-Partida, E., 2017, Mesozoic magmatic-hydrothermal iron oxide deposits (IOCG 'clan') in Mexico: Ore Geology Reviews, 81P3, 1084-1095.

Camprubí, A., Tolson, G., Centeno-García, E., Ortega, B., Bolaños, D., Portugal-Reyna, J.L., Aguilar-Hernández, J.A., CoronaChávez, P., 2011, Mineralogy, ${ }^{40} \mathrm{Ar} /{ }^{39} \mathrm{Ar}$ dating and structural analysis of the Peña Colorada magnetite deposits (Colima, Mexico), in Barra, F., Reich, M., Campos, E., and Tornos, F. (eds.), $11^{\text {th }}$ SGA Biennial 
Meeting — Let's talk ore deposits, Ediciones Universidad Católica del Norte, Antofagasta, Chile, 2, 446-448.

Cebula, G.T., Kunk, M.J., Mehnert, H.H., Naeser, C.W., Obradovich, J.D., Sutter, J.F., 1986, The Fish Canyon Tuff: A potential standard for the ${ }^{40} \mathrm{Ar} /{ }^{39} \mathrm{Ar}$ and fission track dating methods: Terra Cognita, 6, 140.

Centeno-García, E., Guerrero-Suastegui, M., Talavera-Mendoza, O., 2008, The Guerrero Composite Terrane of western Mexico: collision and subsequent rifting in a suprasubduction zone: Geological Society of America Special Paper, 436, 279-308.

Chen, W.T., Zhou, M.-F., 2014, Ages and compositions of primary and secondary allanite from the Lala Fe-Cu deposit, SW China: Implications for multiple episodes of hydrothermal events: Contributions to Mineralogy and Petrology, 168, 1-20.

Chen, H., Clark, A.H., Kyser, T.K., Ullrich, T.D., Baxter, R., Chen, Y., Moody, T.C., 2010, Evolution of the giant Marcona-Mina Justa iron oxide-copper-gold district, SouthCentral Peru: Economic Geology, 105, 155-185.

Corbett, G.H., Leach, T.M., 1998, Southwest Pacific rim gold-copper systems: structure, alteration and mineralization: Society of Economic Geologists, Special Publication, 6, $238 \mathrm{p}$.

Corona-Esquivel, R., Henríquez, F., 2004, Modelo magmático del yacimiento de hierro Peña Colorada, Colima, y su relación con la exploración de otros yacimientos de hierro en México: Universidad Nacional Autónoma de México, Instituto de Geología, Boletín, $113,97 \mathrm{p}$.

Corriveau, L., 2007, Iron oxide copper-gold deposits: a Canadian perspective, in Goodfellow, W.D. (ed.), Mineral deposits of Canada: a synthesis of major deposittypes, district metallogeny, the evolution of geological provinces, and exploration methods: Geological Association of Canada, Mineral Deposits Division, Special Publication, 5, 307-328.

Dare, S.A.S., Barnes, S.-J., Beaudoin, G., 2012, Variation in trace element content of magnetite crystallized from a fractionating sulfide liquid, Sudbury, Canada: implications for provenance discrimination: Geochimica et Cosmochimica Acta, 88, 27-50.

Dalrymple, G.B., Alexander, E.C., Lanphere, M.A., Kraker, G.P., 1981, Irradiation of samples for ${ }^{40} \mathrm{Ar} /{ }^{39} \mathrm{Ar}$ dating using the Geological Survey TRIGA reactor: U.S. Geological Survey Professional Paper, 1176, $55 \mathrm{p}$.

deMelo, G.H.G., Monteiro, L.V.S., Xavier, R.P., Moreto, C.P.N., Santiago, E.S.B., Dufrane, S.A., Aires, B., Santos, A.F.F., 2017, Temporal evolution of the giant Salobo IOCG deposit, Carajás Province (Brazil): constraints from paragenesis of hydrothermal alteration and U-Pb geochronology: Mineralium Deposita, 52, 709-732.

Donelick, R.A., O’Sullivan, P.B., Ketcham, R.A., 2005, Apatite fission-track analysis: Reviews in Mineralogy and Geochemistry, 58, 49-94.

Dupuis, G., Beaudoin, G., 2011, Discriminant diagrams for iron oxide trace element fingerprinting of mineral deposit types: Mineralium Deposita, 46, 319-335.

Galbraith, R.F., 1981, On statistical models for fission track counts: Journal of the International Association for Mathematical Geology, 13, 471-478.

Garduño-Monroy, V.H., Saucedo-Girón, R., Jiménez, Z., Gavilanes-Ruiz, J.C., CortésCortés, A., Uribe-Cifuentes, R.M., 1998, La falla Tamazula, límite suroriental del Bloque Jalisco, y sus relaciones con el complejo volcánico de Colima, México: Revista Mexicana de Ciencias Geológicas, 15, 132-144.

Gleadow, A.J.W., Duddy, I.R., Green, P.F., Lovering, J.F., 1986, Confined fission track 
lengths in apatite: a diagnostic tool for thermal history analysis: Contributions to Mineralogy and Petrology, 94, 405-415.

González-Reyna, J., 1956, Riqueza minera y yacimientos minerales de México, $3^{\text {rd }}$ edition: Banco de México, S.A., Departamento de Investigaciones Industriales, $497 \mathrm{p}$.

Harlov, D.E., Meighan, C.J., Kerr, I.D., Samson, I.M., 2016, Mineralogy, chemistry, and fluidaided evolution of the Pea Ridge Fe oxide-(Y + REE) deposit, Southeast Missouri, USA: Economic Geology, 111, 1963-1984.

Hasebe, N., Barbarand, J., Jarvis, K., Carter, A., Hurford, A.J., 2004, Apatite fission-track chronometry using laser ablation ICP-MS: Chemical Geology, 207, 135-145.

Haugerud, R.A., Kunk, M.J., 1988, Ar/Ar*, a computer program for reduction of ${ }^{40} \mathrm{Ar} /{ }^{39} \mathrm{Ar}$ data: U.S. Geological Survey, Open File Report 88-261, 68 p.

Hawkins, T., Smith, M.P., Herrington, R.J., Maslennikov, V., Boyce, S.J., Jeffries, T., Creaser, R.A., 2017, The geology and genesis of the iron skarns of the Turgai belt, northwestern Kazakhstan: Ore Geology Reviews, 85, 216-246.

Hitzman, M.W., Oreskes, N., Einaudi, M.T., 1992, Geological characteristics and tectonic setting of Proterozoic iron oxide $\left(\mathrm{Cu}-\mathrm{U}-\mathrm{Au}^{-}\right.$ REE) deposits: Precambrian Research, 58, 241-287.

Jonsson, E., Harlov, D.E., Majka, J., Högdahl, K., Persson-Nilsson, K., 2016, Fluorapatitemonazite-allanite relations in the Grängesberg apatite-iron oxide ore district, Bergslagen, Sweden: American Mineralogist, 101(8), 1769-1782.

Klemic, H., 1970, Iron ore deposits of the United States of America, Puerto Rico, Mexico and Central America, in Survey of World Iron Ore Resources, New York, United Nations, 411-477.

Kunk, M.J., Sutter, J.F., Naeser, C.W., 1985, Highprecision ${ }^{40} \mathrm{Ar} /{ }^{39} \mathrm{Ar}$ ages of sanidine, biotite, hornblende, and plagioclase from the Fish
Canyon tuff, San Juan volcanic field, Southcentral Colorado [abs.]: Geological Society of America Abstracts with Programs, 17, 636.

Kunk, M.J., Winick, J.A., Stanley, J.O., 2001, ${ }^{40} \mathrm{Ar} /{ }^{39} \mathrm{Ar}$ age-spectrum and laser fusion data for volcanic rocks in west central Colorado: U.S. Geological Survey Open-File Report, 01-472, $94 \mathrm{p}$.

Li, S., Yang, X., Sun, W., 2015, The Lamandau IOCG deposit, southwestern Kalimantan Island, Indonesia: Evidence for its formation from geochronology, mineralogy, and petrogenesis of igneous host rocks: Ore Geology Reviews, 68, 43-58.

Lindsley, S.H., 1983, Pyroxene thermometry: American Mineralogist, 68, 477-493.

Lodders, K, 2010, Solar system abundances of the elements, in Goswami, A., and Reddy, B.E. (eds.), Principles and perspectives in cosmochemistry: Kodai School on Synthesis of Elements in Stars, Kodaikanal Observatory, India, April 29-May 13, 2008, Berlin, Heidelberg, Springer Verlag, Lecture Notes, 379-417.

Mao, M., Rukhlov, A.S., Rowins, S.M., Spence, J., Coogan, L.A., 2016, Apatite trace element compositions: A robust new tool for mineral exploration: Economic Geology, 111, 1187-1222.

Mapes-Vázquez, E., 1956, Generalidades sobre los yacimientos ferríferos de Aquila, Mich.: Unpublished report, Instituto Nacional para la Investigación de Recursos Minerales, 5 p.

Martinsson, O., Billström, K., Broman, C., Weihed, P., Wanhainen, C., 2016, Metallogeny of the Northern Norrbotten Ore Province, Northern Fennoscandian Shield with emphasis on IOCG and apatiteiron ore deposits: Ore Geology Reviews, 78, 447-492.

McDonough, W.F., Sun, S.S., 1995, The composition of the Earth: Chemical Geology, 120(3-4), 223-253.

Miles, A.J., Graham, C.M., Hawkesworth, C.J., 
Gillespie, M.R., Hinton, R.W., Bromiley, G.D., 2014, Apatite: A new redox proxy for silicic magmas?: Geochimica et Cosmochimica Acta, 132, 101-1 19.

Moreto, G.P.N., Monteiro, L.V.S., Xavier, R.P., Creaser, R.A., DuFrane, S.A., Tassinari, C.C.G., Sato, K., Kemp, A.I.S., Amaral, W.S., 2015, Neoarchean and paleoproterozoic iron oxide-copper-gold events at the sossego deposit, Carajás Province, Brazil: Re-Os and $\mathrm{U}-\mathrm{Pb}$ geochronological evidence: Economic Geology, 110, 809-835.

Mukherjee, R., Venkatesh, A.S., Fareeduddin, 2017, Chemistry of magnetite-apatite from albitite and carbonate-hosted Bhukia Gold Deposit, Rajasthan, western India - An IOCG-IOA analogue from Paleoproterozoic Aravalli Supergroup: Evidence from petrographic, LA-ICP-MS and EPMA studies: Ore Geology Reviews, 91, 509-529.

Murillo, G., Torres, R., 1987, Mapa petrogenético y radiométrico de la República Mexicana: México, Instituto Mexicano del Petróleo, Subdirección de Tecnología de Exploración, Proyecto C-2010, Unpublished Report, 115 p.

Nadoll, P., Angerer, T., Mauk, J.L., French, D., Walshe, J., 2014, The chemistry of hydrothermal magnetite: a review: Ore Geology Reviews, 61, 1-32.

Naslund, H.R., Henríquez, F., Nyström, J.O., Vivallo, W., Dobbs, F.M., 2002, Magmatic iron ores and associated mineralization: examples from the Chilean high Andes and Coastal Cordillera, in Porter, T.M. (ed.), Hydrothermal iron oxide copper-gold and related deposits: A global perspective, vol. 2: Adelaide, Australia, PGG Publishing, 207-226.

Nieto-Samaniego, A.F., Alaniz-Álvarez, S.A., Camprubí, A., 2005, La Mesa Central de México: estratigrafía, estructura y evolución tectónica cenozoica: Boletín de la Sociedad Geológica Mexicana, 57, 285-318.
Nieto-Samaniego, A.F., Alaniz-Álvarez, S.A., Camprubí, A., 2007, The Central Mesa of México: stratigraphy, structure and tectonic evolution during the Cenozoic, in Alaniz-Álvarez, S.A., Nieto-Samaniego, A.F. (eds.), Geology of México: Celebrating the Centenary of the Geological Society of México, The Geological Society of America Special Paper, 422, 41-70.

Nold, J.L., Dudley, M.A., Davidson, P., 2014, The Southeast Missouri (USA) Proterozoic iron metallogenic province-Types of deposits and genetic relationships to magnetiteapatite and iron oxide-- ${ }^{-}$pper- ${ }^{-}$old deposits: Ore Geology Reviews, 57, 154-171.

Piccoli, P.M., Candela, P.A., 2002, Apatite in igneous systems: Reviews in Mineralogy and Geochemistry, 48, 255-292.

Pollard, P.J., 2006, An intrusion-related origin for $\mathrm{Cu}-\mathrm{Au}$ mineralization in iron oxidecopper-gold (IOCG) provinces: Mineralium Deposita, 41, 179-187.

Richards, J., Mumin, A.H., 2013, Lithospheric fertilization and mineralization by arc magmas: genetic links and secular differences between porphyry copper \pm molybdenum \pm gold and magmatic-hydrothermal iron oxide-copper-gold deposits, in Colpron, M., Bissig, T., Rusk, B.G., Thompson, J.F.H., (eds.), Tectonics, metallogeny, and discovery: the North American Cordillera and similar accretionary settings: Society of Economic Geologists, Special Publication, 17, 277-300.

Ruvalcaba-Ruiz, D.F., 1983, Geology and origin of the Aquila iron deposit in Southwestern Michoacán, Mexico: Unpublished PhD dissertation, Colorado State University, Fort Collins, Colorado, USA, 155 p.

Sánchez-Quiroz, S., Juárez, A., 1988, Modelo geológico para exploración de yacimientos de Fe en la Sierra Madre del Sur: Unpublished report, HYLSA, S.A. de C.V., 208 p.

Sillitoe, R.H., 2003, Iron oxide-copper-gold deposits: an Andean view: Mineralium 
Deposita, 38, 787-812.

Sillitoe, R.H., Perelló, J., 2005, Andean copper province: tectonomagmatic settings, deposit types, metallogeny, and discovery, in Hedenquist, J.W., Thompson, J.F.H., Goldfarb, R.J., and Richards, J.P. (eds.), Economic Geology $100^{\text {th }}$ Anniversary Volume: Littleton, Colorado, USA, Society of Economic Geologists, 845-890.

Smith, M., Coppard, J., Herrington, R., Stein, H., 2007, The geology of the Rakkurijärvi $\mathrm{Cu}-\mathrm{Au})$ prospect, Norrbotten: A new iron oxide-copper-gold deposit in north Sweden: Economic Geology, 102, 393-414.

Smith, M.P., Storey, C.D., Jeffries, T.E., Ryan, C., 2009, In situ U-Pb and trace element analysis of accessory minerals in the Kiruna District, Norrbotten, Sweden: New constraints on the timing and origin of mineralization: Journal of Petrology, 50, 2063-2094.

Snee, L.W., Sutter, J.F., Kelly, W.G., 1988, Thermochronology of economic mineral deposits: Dating the stages of mineralization at Panasqueira, Portugal, by high precision ${ }^{40} \mathrm{Ar} /{ }^{39} \mathrm{Ar}$ age spectrum techniques on muscovite: Economic Geology, 83, 335-354.

Solé, J., Salinas, J.C., González-Torres, E., Cendejas-Cruz, J.E., 2007, Edades K/Ar de 54 rocas ígneas y metamórficas del Occidente, Centro y Sur de México: Revista Mexicana de Ciencias Geológicas, 24, 104-119.

Steiger, R.H., Jäger, E., 1977, Subcommission on geochronology: convention on the use of decayconstantsingeo-and cosmochronology: Earth and Planetary Science Letters, 36, 359-362.

Stosch, H.-G., Romer, R.L., Daliran, F., Rhede, D., 2011, Uranium-lead ages of apatite from iron oxide ores of the Bafq District,
East-Central Iran: Mineralium Deposita, 46, 9-21.

Tritlla, J., Camprubí, A., Corona-Esquivel, R., Centeno-García, E., Iriondo, A., Sánchez-Martínez, S., Gasca-Durán, A.A., Cienfuegos-Alvarado, E., Morales-Puente, P., 2003, Estructura y edad del depósito de Peña Colorada (Colima): un posible equivalente Fanerozoico de los depósitos de tipo IOGG: Revista Mexicana de Ciencias Geológicas, 20, 182-201.

Vélez-López, J., Ortiz-Sandoval, L., CárdenasFlores, D., Hernández-García, J.F., González-Aguilar, J.L., Anaya-Renovato, C., 1977, Estudio geológico-magnetométrico en los yacimientos de fierro de la región sur del estado de Jalisco y noroeste del estado de Michoacán: Unpublished report, Consejo de Recursos Minerales, 160 p.

Westhues, A., Hanchar, J.M., Whitehouse, M.J., Martinsson, O., 2016, New constraints on the timing of host-rock emplacement, hydrothermal alteration, and iron oxideapatite mineralization in the Kiruna District, Norrbotten, Sweden: Economic Geology, 111, 1595-1618.

Zhu, C., Sverjensky, D.A., 1991, Partitioning of F-Cl-OH between minerals and hydrothermal fluids: Geochimica et Cosmochimica Acta, 55, 1837-1858.

Zhu, Z., Tan, H., Liu, Y., Li, C., 2018, Multiple episodes of mineralization revealed by Re-Os molybdenite geochronology in the Lala Fe-Cu deposit, SW China: Mineralium Deposita, 53, 311-322.

Zürcher, L., Ruiz, J., Barton, M.D., 2001, Paragenesis, elemental distribution and stable isotopes at the Peña Colorada iron skarn, Colima, México: Economic Geology, 96, 535-557. 